\title{
PERANGKAT PEMBELAJARAN MATEMATIKA MENGGUNAKAN PENDEKATAN PMRI DENGAN KONTEKS BUDAYA MASOHI \\ PADA MATERI PERBANDINGAN SENILAI \\ (Penelitian Pengembangan Pada Siswa Kelas VII SMP Negeri 1 Masohi)
}

\section{TESIS}

Diajukan Sebagai Salah Satu Syarat Untuk Memperoleh Gelar Magister Pendidikan Pada Program Studi S2 Pendidikan Matematika Program Pascasarjana Universitas Negeri Manado

Oleh

Emy Sohilait, S.Pd

15811010

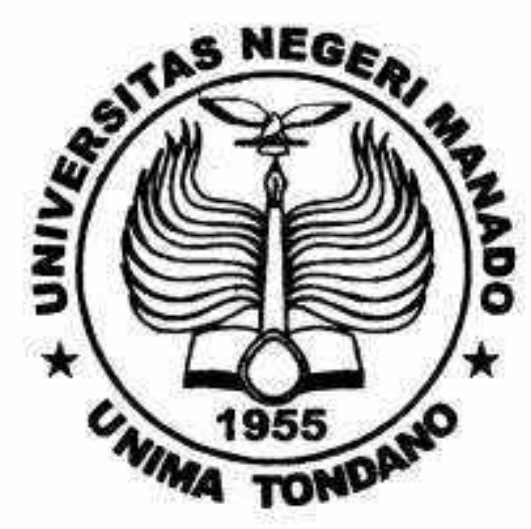

UNIVERSITAS NEGERI MANADO

PROGRAM PASCASARJANA

PROGRAM STUDI S2 PENDIDIKAN MATEMATIKA

TAHUN 2017 


\section{KEMENTERIAN RISET TEKNOLOGI DAN PENDIDIKAN TINGGI UNIVERSITAS NEGERI MANADO \\ PROGRAM PASCASARJANA}

Kampus Pascasarjana Unima Tondano Telp.(0431) 822335 Fax.(0431) 822335

Website: www.pasca-unima.ac.id email:tu@pasca-unima.ac.id

\section{REKOMENDASI}

Nama : Emy Sohilait

NIM $\quad: 15811010$

Program Studi : S2 PendidikanMatematika

JudulTesis

: Peranglkat Pembelajaran Matematika Menggunakan Pendekatan PMRI Dengan Konteks Budaya Masohi Pada Materi Perbandingan Senilai

Telah disetujui oleh komisi pembimbing untuk diajukan kepada Panitia Ujian Komprehensif Program Studi S2 Pendidikan Matematika program Pascasarjana Universitas Negeri Manado.

\section{Komisi Pembimbing}

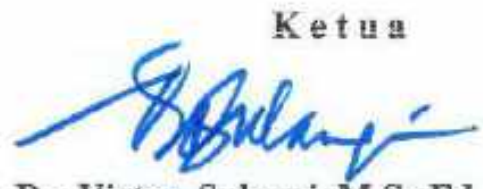

Dr. Victor Sulangi, M.Sc.Ed

NIP. 195107041986031001

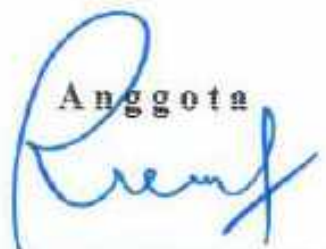

Dr. T. A. S. Rembet, M.Se

NIP. 195302251980012001

Menyetujui:

Ketua Program Studi Pendidikan Matematika

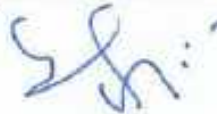

Dr. S. M. Salajang, M.Si

NIP: 196009231987101001

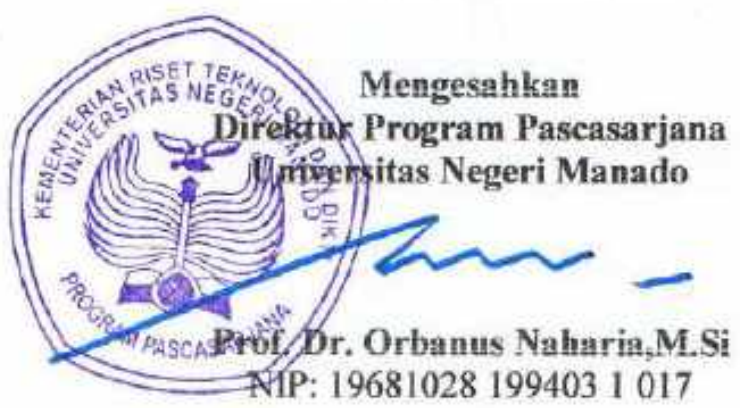




\section{KEMENTERIAN RISET, TEKNOLOGI DAN PENDIDIKAN TINGGI UNIVERSITAS NEGERI MANADO \\ PROGRAM PASCASARJANA}

Kampus Pascasarjana UNIMA Tondano. Telp. (0431) 822335, Fax. (0431) 822335

Website: www pasca-unima ac id, email tu@pasca-unima ac id

\section{BUKTI PENGESAHAN PERBAIKAN TESIS}

Kami yang bertandatangan dibawahini, Komisi Penguji Hasil Penelitian Tesis Program Studi

S2 Pendidikan Maternatika Pascasarjana Universitas Negeri Manado, menerangakan bahwa:

Nama : Emy Sohilait, S.Pd

NIM

: 15811010

Program Studi

: S2 PendidikanMatematika

JudukTesis

: Perangkat Pembelajaran Matematika Menggunakan

Pendekatan PMRI Dengan Konteks Budaya Masohi Pada

Materi Perbandingan Senilai

Hari / Tanggal Ujian : Senin, 28 Agustus 2017

Telah memperbaiki Tesis sesuai dengan Komisi Penguji. Demikian Surat keterangan ini dibuat untuk dipergunakan sebagiamana mestinya.

\begin{tabular}{|c|c|c|c|}
\hline No & Nama & igan & Tanggal \\
\hline 1. & Prof. Dr. Orbanus Naharia, M.Si & & \\
\hline 2. & Prof. Dr. Sanusi Gugule, MS & & 94 Gedarber 207 \\
\hline 3. & Dr. Santje M. Salajang. M.Si & & 12 stokember 2077 \\
\hline 4. & Dr. I Wayan Damai, M.Pd & & 08500 tamber 2017 \\
\hline 5. & Dr.Victor Sulangi, M.Sc Ed & & seecenver \\
\hline 6. & Dr. Treesje A. S. Rembet, M.Sc & & 4 seykember 2017 \\
\hline 7. & Dr. Jhon R. Wenas, MS & & 12 Septermber 2017 \\
\hline 8. & Dr. Olivia Lalamentik, M.Si & & 09 septamber 2017 \\
\hline 9. & Dr. Rosiah J.Pulukadang, M.Pd & & 11 September 2017 \\
\hline
\end{tabular}




\section{SURAT PERNYATAAN}

Yang bertandatangan di bawah ini :

$\begin{array}{ll}\text { Nama } & \text { : Emy Sohilait } \\ \text { NIM } & : 15811010 \\ \text { Judul Tesis } & \text { : PERANGKAT PEMBELAJARAN MATEMATIKA } \\ & \text { MENGGUNAKAN PENDEKATAN PMRI DENGAN KONTEKS } \\ & \text { BUDAYA MASOHI PADA MATERI PERBANDINGAN SENILAI }\end{array}$

Menyatakan dengan sebenarnya bahwa :

1. Tesis yang telah berhasil saya susun dan sepenuhnya hasil karya sendiri.

2. Bila dikemudian hari ternyata terdapat bukti-bukti yang meyakinkan bahwa Tesis ini merupakan jiplakan dari karya orang lain, saya bersedia menanggung segala akibat yang ditimbulkan oleh tindakan tersebut.

Demikian pernyataan ini dibuat untuk dapat digunakan sebagaimana mestinya.

Tondano, Agustus 2017

Pembuat Pernyataan,

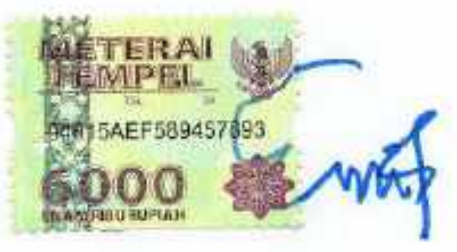

Emy Sohilait 


\section{MOTTO DAN PERSEMBAHAN}

\section{MOTTO}

Ia membuat segala sesuatu indah pada waktunya (Pengkhotbah 3:11a)

\section{PERSEMBAHAN}

Dengan penuh rasa syukur dan suka cita dipanjatkan ke hadirat Tuhan Yesus karya ini kupersembahkan kepada:

- Papa Di surga dan Mama Tersayang

- Kakak dan Keponakan

- Seluruh keluarga besar Sohilait-Huwae

- Almamaterku tercinta, Gereja dan Bangsa 


\title{
PERANGKAT PEMBELAJARAN MATEMATIKA MENGGUNAKAN \\ PENDEKATAN PMRI DENGAN KONTEKS BUDAYA MASOHI \\ PADA MATERI PERBANDINGAN SENILAI
}

\author{
Emy Sohilait $^{*}$, Victor Sulangi ${ }^{2 *}$, Treesje A. S. Rembet ${ }^{3}$
}

1) Prodi S2 Pendidikan Matematika PPs UNIMA Email: sohilaitemy@ gmail.com

2) Prodi S2 Pendidikan Matematika PPs UNIMA Email: vsulangi@yahoo.com

\begin{abstract}
ABSTRAK
Penelitian ini merupakan penelitian pengembangan perangkat pembelajaran matematika pada materi Perbandingan Senilai melalui pendekatan PMRI dengan memperhatikan dugaan lintasan belajar siswa. Tujuan penelitian ini untuk menghasilkan perangkat pembelajaran yang valid, praktis dan efektif didasarkan pada dugaan lintasan belajar. Desain pembelajaran dipilih sebagai jenis penelitian untuk mencapai tujuan tersebut yang terdiri dari tahap desain awal, tahap uji coba pembelajaran, dan tahap analisis tinjauan. Subjek penelitian ini adalah siswa kelas VII SMP Negeri 1 Masohi. Hasil penelitian ditemukan (1) lintasan belajar siswa dengan konteks budaya Masohi berkembang dari tahap informal menuju tahap formal dapat mendukung pemahaman siswa pada materi Perbandingan Senilai, (2) kemampuan guru mengelola pembelajaran efektif, (3) aktivitas siswa dalam pembelajaran efektif, (4) respon siswa terhadap perangkat pembelajaran positif, (5) perangkat tes hasil belajar memenuhi kriteria valid dan reliabel, (6) ketuntasan belajar siswa tuntas. Berdasarkan hasil penelitian ini, didapatkan bahwa perangkat pembelajaran matematika melalui pendekatan PMRI yang didasarkan lintasan belajar dapat digunakan.
\end{abstract}

Kata Kunci: PMRI, Perangkat Pembelajaran,Valid, Praktis, Efektif 


\title{
MATHEMATICAL LEARNING DEVICE USING PMRI APPROACH WITH MASOHI CULTURAL CONTEXT IN DIRECT PROPORTION
}

\author{
Emy Sohilait ${ }^{1 *}$, Victor Sulangi ${ }^{2 *}$, Treesje A. S. Rembet ${ }^{3}$
}

1) Prodi S2 Pendidikan Matematika PPs UNIMA Email: sohilaitemy@gmail.com

2) Prodi S2 Pendidikan Matematika PPs UNIMA Email: vsulangi@yahoo.com

\begin{abstract}
This research is a research of mathematics learning device development on direct proportion through PMRI approach by taking into account hypothetical learning trajectory allegation. The purpose of this study to produce a valid, practical and effective learning tool based on the alleged hypothetical learning trajectory. The instructional design was chosen as the type of research to achieve the objectives, consisting of the preliminary design phase, the teaching experiment phase, and the retrospective analysis phase. The subject of this reseacrh is the students of class VII SMP Negeri Masohi. The results of the study were found (1) the learning trajectory with the Masohi cultural context developed from the informal stage to the formal stage can support students understanding on the direct proportion, (2) the ability of the teacher to manage effective learning, (3) the student activity in effective learning, (4) students responses to positive learning devices, (5) test results of learning instruments meet valid and reliable criteria, (6) complete student learning thoroughness. The result of this research, found that mathematics learning device through PMRI approach based on alleged learning trajectory can be used.
\end{abstract}

Keywords: PMRI, Learning Device, Valid, Practical, Effective 


\section{KATA PENGANTAR}

Penelitian pengembangan atau dikenal dengan penelitian Research \& Development saat ini sangat berpengaruh dalam dunia pendidikan karena dengan adanya penelitian pengembangan ini para peneliti dan tenaga pendidikan bisa terus melakukan inovasi di bidang Ilmu Pengetahuan dan Teknologi. Salah satu syarat di Program Pascasarjana Program Studi Pendidikan Matematika Universitas Negeri Manado adalah melakukan penelitian tesis Research \& Development guna memberikan hasil output yang mampu bersaing di Era Masyarakat Ekonomi Asia dan mampu melakukan inovasi agar supaya pendidikan di Indonesia tidak ketinggalan dibanding dengan Negara-negara maju dan berkembang.

Penelitian pada tesis yang berjudul: "Perangkat Pembelajaran Matematika Menggunakan Pendekatan PMRI dengan Konteks Budaya Masohi pada Materi Perbandingan Senilai” disusun sesuai dengan konsep dan langkah-langkah penelitian pengembangan Research \& Development khususnya model design research yang terdiri dari 3 tahap. Penelitian tesis ini dilakukan guna memenuhi syarat untuk memperoleh gelar Magister Pendidikan pada Program Studi Pendidikan Matematika, Universitas Negeri Manado. Penulis menyadari bahwa penyelesaian Tesis ini adalah anugerah dari Tuhan Yesus. Karena melihat keterbatasan yang dimiliki oleh penulis, membuktikan bahwa sepenuhnya harus bergantung pada Tuhan Yesus. Saran dan masukan dari pembaca diperlukan dalam tahap penyempurnaan tesis ini.

Akhirnya, semoga tesis ini dapat bermanfaat bagi dunia pendidikan Indonesia sebagai bagian upaya peningkatan kualitas pembelajaran matematika pada peningkatan hasil belajar siswa.

Tondano, September 2017

Penulis 


\section{UCAPAN TERIMA KASIH}

Puji dan syukur penulis panjatkan kehadirat kepada Tuhan Yang Maha Esa karena hanya oleh kasih, kemurahan, anugerah dan berkat-Nya sehingga tesis ini dapat terselesaikan. Banyak masukan dan bantuan dari berbagai pihak selama penelitian dan penyusunan tesis ini, demikian pula saat menempuh perkuliahan. Untuk itu, pada kesempatan ini, penulis mengucapkan terima kasih kepada:

1. Rektor Universitas Negeri Manado : Prof. Dr. Julyeta P. A. Runtuwene, MS Direktur Program Pascasarjana : Prof. Dr. OrbanusNaharia, M.Si

Asisten Direktur I

Asisten Direktur II

Asisten Direktur III Asisten Direktur IV
: Prof. Dr. Sanusi Gugule, MS

: Dr. Tiene M. B. Turangan, MS

: Dr. O. J. Lalamentik, M.Si

: Dr. Masje Wurarah, M.Si

2. Dr. Santje M. Salajang, M.Si selaku Ketua Program Studi S2 Pendidikan Matematika UNIMA.

3. Dr. I Wayan Damai, M.Pd, M.Sc, selaku Sekertaris Program Studi S2 Pendidikan Matematika UNIMA.

4. Dr. Victor R. Sulangi, M.Sc.Ed selaku Pembimbing I yang telah dengan sabar dan tidak kenal lelah memberi petunjuk, membimbing dan memotivasi penulis untuk menyelesaikan tesis ini.

5. Dr. Treesje A. S. Rembet, M.Sc selaku Pembimbing II yang juga banyak memberikan bimbingan dan arahan yang sangat berguna melalui diskusidiskusi selama penyelesaian tesis ini.

6. Para pengajar pada Program Studi S2 Pendidikan Matematika Pascasarjana UNIMA yang telah memberikan ilmu pengetahuan pada penulis.

7. L Leuwol, S.AP selaku kepala SMP Negeri 1 Masohi serta validator yang telah memberikan izin melaksanakan penelitian dan memberikan arahan selama pelaksanaan penelitian.

8. Selfi Nundehu, S.Pd selaku guru mitra serta validator yang telah bersedia bekerjasama dan banyak memberikan masukan pada penelitian. 
9. Rekan-rekan mahasiswa Program Studi Pendidikan Matematika Program Pascasarjana Unima angkatan 2015 atas masukan melalui diskusi-diskusi yang dilakukan.

10. Orang tuaku, Reinholp Sohilait (Alm), Selfina Huwae, Lukas Rommer dan Chornelia Sohilait yang dengan penuh pengorbanan, kasih sayang, membesarkan, mendidik dan membiayai serta selalu berdoa untuk keberhasilan penulis.

Semoga Tuhan melimpahkan berkat dan anugerah-Nya kepada semua pihak yang telah memberikan bantuan dalam penyelesaian tesis ini.

Tondano, September 2017

Penulis 


\section{DAFTAR ISI}

LEMBAR PENGESAHAN ........................................................... i

LEMBAR PERNYATAAN ...............................................................ii

MOTTO DAN PERSEMBAHAN .........................................................ii

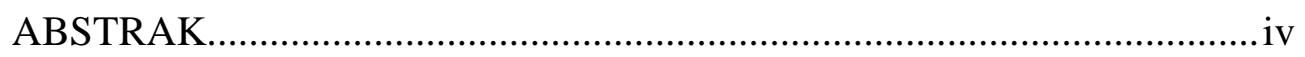

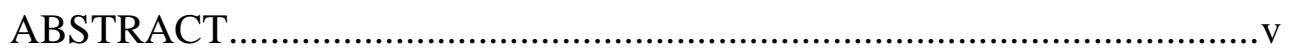

KATA PENGANTAR ................................................................... vi

UCAPAN TERIMA KASIH................................................................ vii

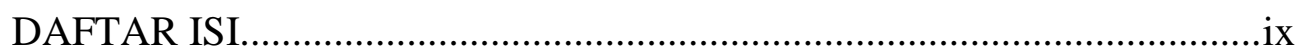

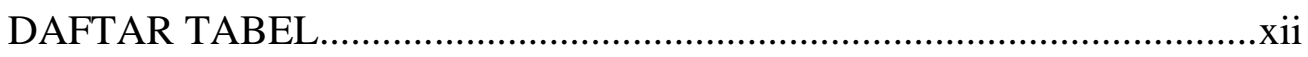

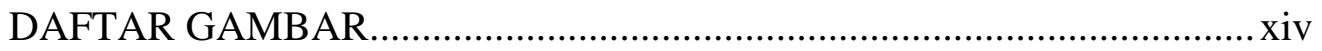

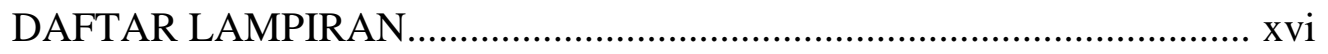

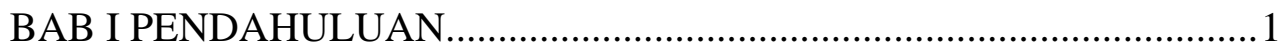

A. Latar Belakang Masalah............................................................. 1

B. Rumusan Masalah......................................................................... 5

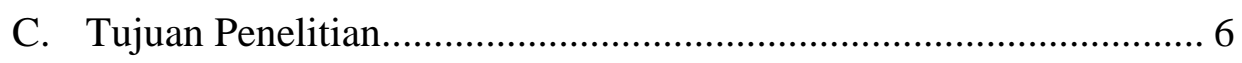

D. Spesifikasi Produk yang Diharapkan............................................ 6

E. Manfaat Penelitian................................................................... 7

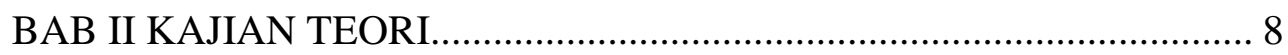

A. Pembelajaran Matematika Realistik Indonesia.............................. 8

B. Pembelajaran Matematika Berbasis Konteks Budaya Maluku.......... 14

C. Pengembangan Model Kepada Pengetahuan Matematika Formal.... 18

D. Desain Soal Kontekstual Melalui Pendekatan PMRI....................... 22 
E. Dugaan Lintasan Belajar Siswa........................................................ 24

F. Perangkat Pembelajaran Matematika.............................................25

G. Kefektifan Pembelajaran..........................................................29

H. Materi Perbandingan Senilai..................................................... 32

I. Kurikulum 2013 Pembelajaran Perbandingan Senilai...................... 34

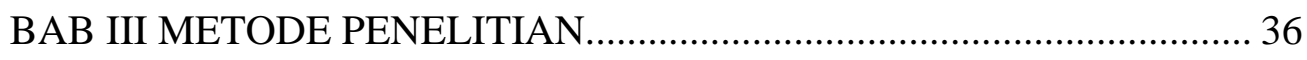

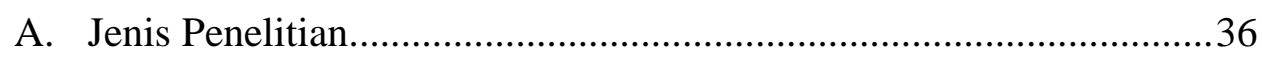

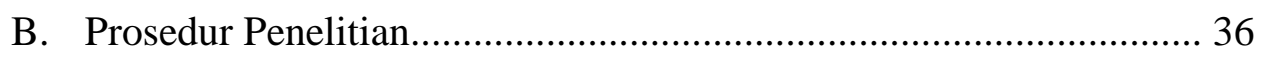

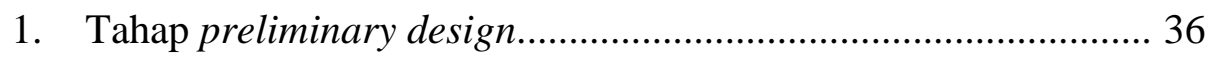

2. Tahap teaching experiment t...................................................... 39

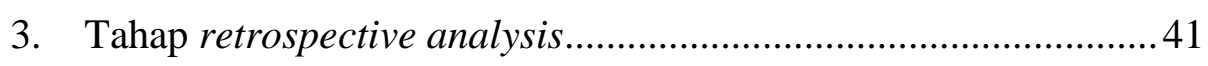

C. Hypothetical Learning Trajectory Pembelajaran Perbandingan

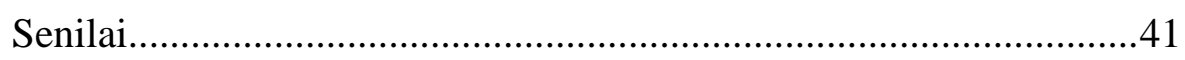

D. Rancangan Iceberg Pembelajaran Perbandingan Senilai.................. 43

E. Instrumen dan Teknik Pengumpulan Data.....................................45

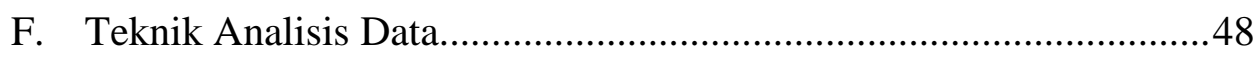

G. Kriteria Perangkat Pembelajaran................................................. 53

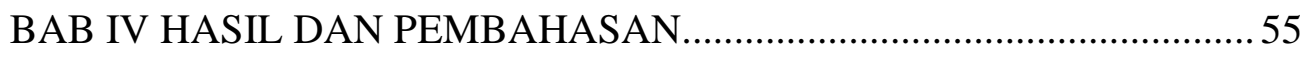

A. Implementasi Desain dan Hasil Pengembangan Perangkat............... 55

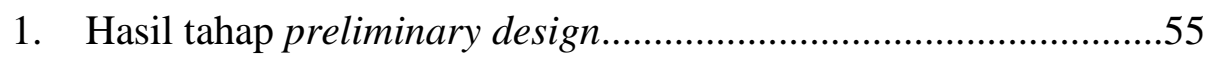

2. Hasil tahap teaching experiment.............................................. 76

3. Hasil tahap retrospective analysis........................................... 89

B. Analisis Deskriptif Hasil Penelitian.............................................. 98 
1. Aktivitas siswa selama pembelajaran..........................................98

2. Kemampuan guru mengelola pembelajaran................................99

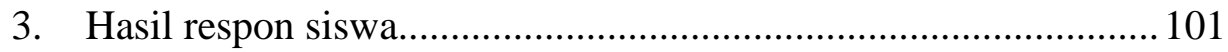

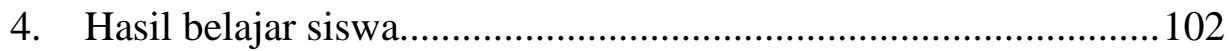

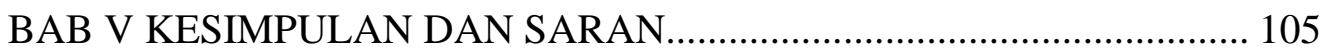

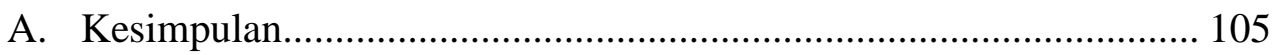

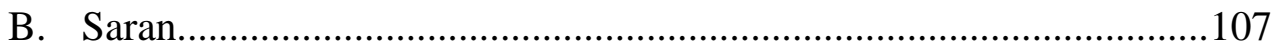

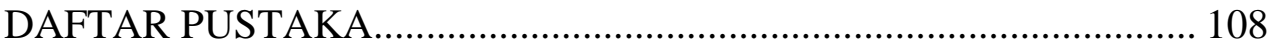

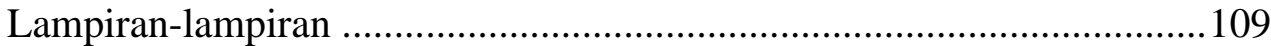




\section{DAFTAR TABEL}

Tabel

halaman

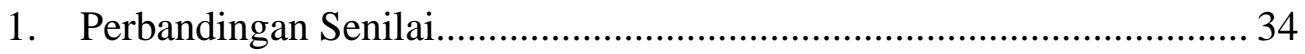

2. Kurikulum Pembelajaran Perbandingan Senilai.................................... 35

3. HLT Pembelajaran Perbandingan Senilai..............................................41

4. Persentase Waktu Ideal Untuk Aktivitas Siswa....................................49

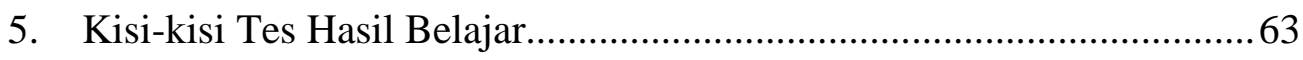

6. Daftar Nama-nama Vaidator.............................................................64

7. Hasil Penilaian Rencana Pelaksanaan Pembelajaran..............................65

8. Revisi Rencanan Pelaksanaan Pembelajaran..........................................66

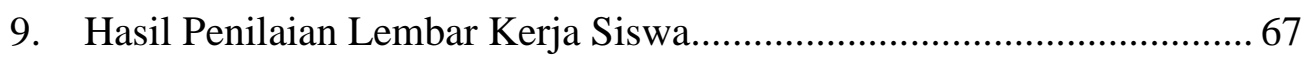

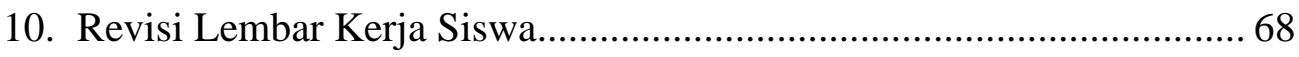

11. Hasil Validitas Tes Hasil Belajar.......................................................... 70

12. Revisi Tes Hasil Belajar................................................................... 71

13. Revisi Berdasarkan Uji Keterbacaan.................................................... 74

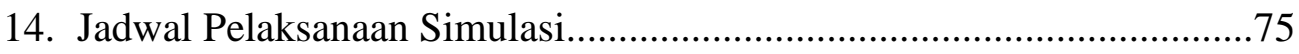

15. Aktivitas Siswa Selama Kegiatan Pembelajaran................................... 90

16. Hasil Pengamatan Kemampuan Guru Mengelola Pembelajaran.......... 91

17. Revisi Rencana Pelaksanaan Pembelajaran............................................94

18. Persentase Perasaan Siswa Terhadap Komponen Mengajar...................96

19. Persentase Pendapat Siswa Terhadap Komponen Pembelajaran............96

20. Persentase Pendapat Siswa tentang Pemahaman Bahasa yang

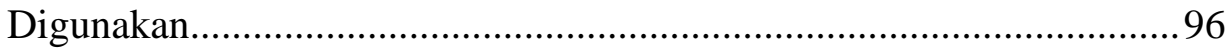


21. Persentase Pendapat Siswa tentang Penampilan (Tulisan,Ilustrasi atau

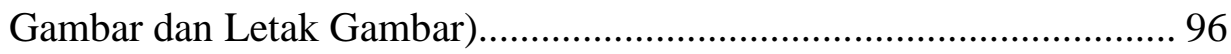

22. Hasil Validitas ButirTes...................................................................... 97

23. Aktivitas Siswa Selama Kegiatan Pembelajaran................................... 99

24. Hasil Pengamatan Kemampuan Guru Mengelola Pembelajaran............ 100

25. Persentase Perasaan Siswa Terhadap Komponen Mengajar................. 101

26. Persentase Pendapat Siswa Terhadap Komponen Pembelajaran............ 101

27. Persentase Pendapat Siswa tentang Pemahaman Bahasa yang digunakan. 102

28. Persentase Pendapat Siswa tentang Penampilan(Tulisan, Ilustrasi atau Gambar dan Letak Gambar). 102

29. Hasil Belajar Siswa Kelas Uji Coba..... 103

30. Pencapaian Keefektifan Pembelajaran Matematika Realistik Indonesia. 103

31. Kriteria Perangkat Pembelajaran yang Valid. 104 


\section{DAFTAR GAMBAR}

Gambar

halaman

1. Rumah Adat Baileo di DesaAllang 16

2. Budaya Cuci Negeri Desa Soya (a) dan Membangun Baileo oleh Suku Nuaulu (b).... 17

3. Budaya Masohi Membagi Beras........................................................ 17

4. Kain Tenun Maluku Tenggara Barat................................................. 17

5. Panas Pela Rumah 3, Wakal \& Hitumesing (a) dan Panas Gandong

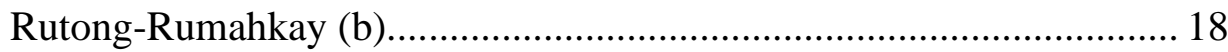

6. Tahap-tahap dalam Pengembangan Model............................................. 19

7. Iceberg Pendekatan PMRI............................................................ 21

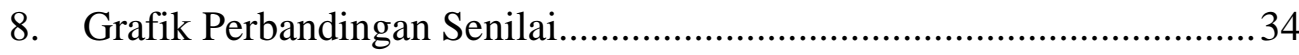

9. Tahap Pelaksanaan Design Research................................................. 36

10. Rancangan Iceberg Pembelajaran Perbandingan Senilai.......................44

11. Antusias Siswa Menjawab Berbagai Pertanyaan...................................77

12. Kelompok-klompok Bekerjasama Menyelesaikan Masalah Kontekstual LKS 1 (kelompok 2 (a), kelompok 3 (b), kelompok 6 (c), kelompok 7 (d))

13. Aktivitas Siswa Membagi Beras...........................................................

14. Gambar 14. Unit-unit Geometri yang Digunakan Siswa Menyelesaikan LKS 1 (kelompok 1 (a), kelompok 4 (b), kelompok 5 (c), kelompok 7 (d))...... 80

15. Kelompok-kelompok Menyelesaikan Masalah LKS 1 dalam Bentuk 
Semi Formal (kelompok 2 (a), kelompok 3 (b), kelompok 6 (c))

16. Hasil Kerja Masing-masing Kelompok untuk LKS 1 (kelompok 1 (a), kelompok 2 (b), kelompok 3 (c), kelompok 4 (d), kelompok 5 (e), kelompok 6 (f), kelompok 7 (g)) 85

17. Iceberg Pembelajaran Perbandingan Senilai......................................... 87

18. Learning Trajectory Pembelajaran Perbandingan Senilai..................... 89 


\section{DAFTAR LAMPIRAN}

Lampiran halaman

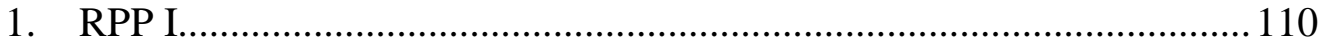

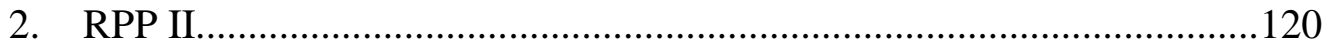

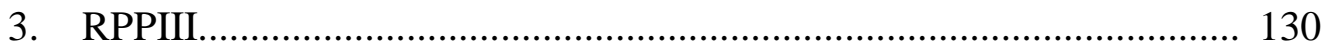

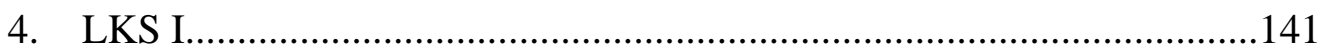

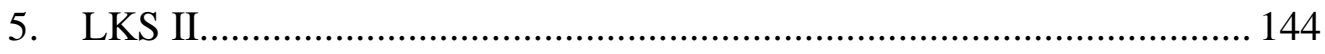

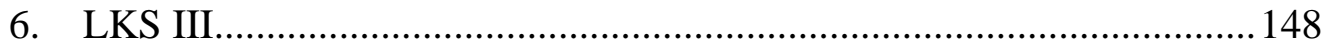

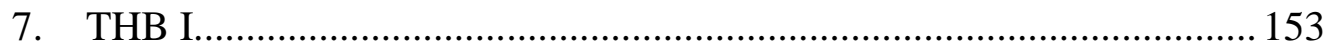

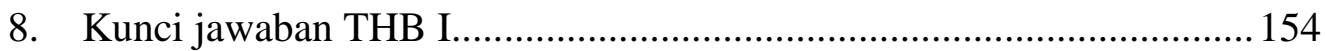

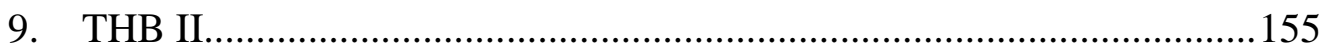

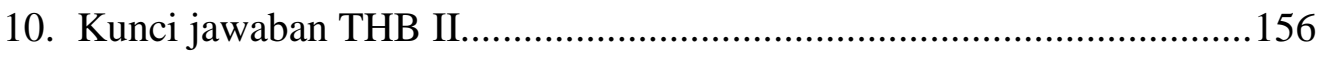

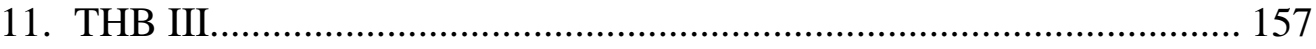

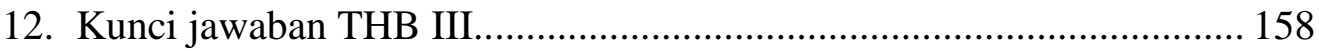

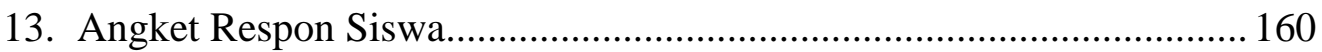

14. Lembar Observasi Kemampuan GuruMengelola Pembelajaran........... 161

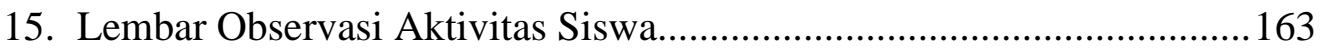

16. Lembar Validasi Kemampuan Guru Mengelola Pembelajaran.............. 165

17. Lembar Validasi Aktivitas Siswa......................................................... 167

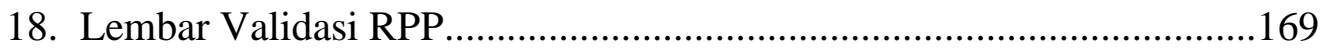

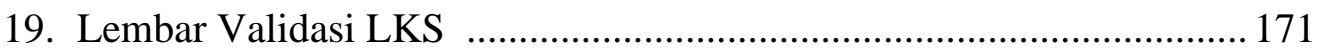

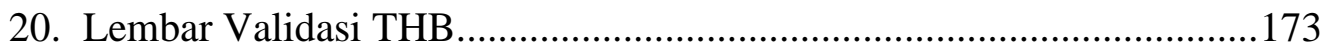

21. Tabel Pesiapan Perhitungan Validitas dan Reliabilitas......................... 175 
22. Validitas Tes Hasil Belajar

23. Reliabilitas Tes Hasil Belajar......................................................... 184

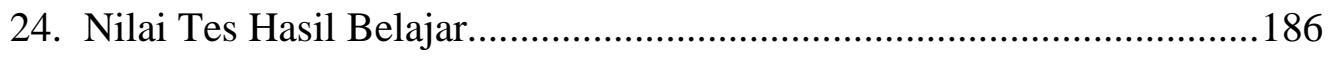




\section{BAB I}

\section{PENDAHULUAN}

\section{A. Latar Belakang Masalah}

Matematika merupakan hal yang sudah tidak asing lagi bagi masyarakat terutama dalam dunia pendidikan. Disadari atau tidak aktivitas manusia selalu membutuhkan pengukuran atau perhitungan baik yang dilakukan oleh ibu rumah tangga ketika membagi beras untuk dimasak dengan jumlah yang sama setiap harinya atau tukang becak yang memperhitungkan jumlah ongkos yang harus dibayar oleh penumpang berdasarkan jarak tempuh. Contoh masalah ini sesuai dengan materi Perbandingan Senilai. Perbandingan Senilai merupakan lanjutan materi Perbandingan yang telah diajarkan di Sekolah Dasar (SD). Materi ini diajarkan lebih lanjut di kelas VII tingkat SMP dengan tujuan siswa mampu menyelesaikan permasalahan kontekstual terkait dengan materi Perbandingan Senilai.

Hasil observasi yang dilakukan peneliti di SMP Negeri 1 Masohi (tanggal 15 Januari 2017), menunjukan siswa mengalami kesulitan dalam memahami materi Perbandingan Senilai dan menggunakannya dalam pemecahan masalah kehidupan mereka. Salah satu penyebabnya adalah pembelajaran di kelas masih didominasi guru. Guru kurang memberikan kesempatan kepada siswa untuk mengkonstruksi pengetahuan mereka sendiri, prakteknya pembelajaran matematika di sekolah pada umumnya, kurang memanfaatkan realitas dunia nyata untuk mengaplikasikan dan atau mematematisasi dunia nyata. Selain itu, faktor lainnya ialah kurang 
tersedianya perangkat pembelajaran matematika yang berbasis aktivitas, sehingga siswa hanya cenderung belajar menghafal konsep atau prinsip matematika tanpa disertai pemahaman yang baik. Akibatnya siswa kurang bertanya dan tidak dapat berpikir secara kritis juga tidak tercipta kerjasama antar siswa.

Awal dari setiap proses pembelajaran di sekolah menurut Suprihatiningrum (2013:108) adalah perencanaan pembelajaran meliputi pendekatan, strategi, metode yang kreatif agar siswa tertarik dalam belajar matematika. Selain pendekatan pembelajaran yang baik, ketersediaan perangkat pembelajaran juga merupakan salah satu faktor yang dapat menunjang proses pembelajaran berjalan dengan baik dan dapat meningkatkan mutu pendidikan. Perangkat pembelajaran memberikan kemudahan dan dapat membantu guru dalam mempersiapkan serta melaksanakan proses pembelajaran di kelas. Oleh sebab itu, yang sangat penting dilakukan sekarang ini adalah mengembangkan perangkat pembelajaran, sekaligus melatih kepada guru suatu pembelajaran yang berbasis aktivitas siswa.

Salah satu pendekatan pembelajaran matematika yang dikembangkan di Indonesia adalah Pembelajaran Matematika Realistik Indonesia (PMRI). Pendekatan ini mengacu pada pendapat Freudenthal (Gravemeijer,1994:90) yang menyatakan bahwa matematika harus dikaitkan dengan realita dan matematika merupakan aktivitas manusia. Ditambahkan juga oleh de Lange (Sutarto,2005:19) proses penemuan kembali harus dikembangkan melalui 
penjelajahan berbagai persoalan dunia real yang merupakan bagian inti dan dijadikan titik awal (starting point) dalam pembelajaran matematika.

Paradigma belajar yang terkandung dalam RME inilah yang mendasari dikembangkannya pembelajaran ini di Indonesia dengan nama PMRI. Dengan demikian, kegiatan pembelajaran dengan menggunakan PMRI merupakan pendekatan pembelajaran yang bertolak dari masalah-masalah yang sesuai dengan pengalaman siswa, dimana siswa harus diberi kesempatan seluas-luasnya untuk menemukan kembali ide atau konsep matematika secara mandiri sebagai akibat dari pengalaman siswa dalam berinteraksi dengan realitas.

Guru di sekolah saat ini dituntut banyak tanggung jawab yang diantaranya adalah mendesain soal matematika sendiri. Hal ini disebabkan beberapa hal di antaranya adalah tuntutan undang-undang, munculnya kurikulum baru, inovasi pembelajaran dan tanggung jawab terkait suksesnya siswa dalam pendidikannya. Pada pasal 10 Undang-Undang Guru dan Dosen Tahun 2005 disebutkan bahwa guru dan dosen yang profesional harus mempunyai empat kompetensi atau kemampuan utama yaitu: kemampuan pedagogik, profesional, kepribadian dan sosial. Untuk kompentensi pedagogik, guru dan dosen dituntut untuk mampu menyiapkan materi pembelajaran, mengajarkannya di kelas dan mengevaluasinya. Menyiapkan pembelajaran diperlukan kemampuan yang salah satunya adalah mendesain sendiri soal-soal yang akan digunakan siswa. Arah pendekatan pembelajaran 
matematika di sekolah saat ini adalah penggunaan konteks dalam pembelajaran matematika.

Pendekatan PMRI dijadikan solusi karena dikembangkan sesuai dengan penggunaan konteks atau situasi yang disesuaikan dengan kemampuan kognitif siswa dalam pembelajaran matematika. Salah satu konteks yang dapat ditawarkan adalah dengan melibatkan budaya yang menjadi dasar dari aktivitas kehidupan siswa sehari-hari, sehingga mudah dipahami oleh siswa karena bersentuhan langsung dengan situasi yang terjadi. Budaya lokal yang ada di provinsi Maluku meliputi budaya Pela dan Gandong, menunjukan hubungan kekerabatan antara negeri Salam dan Sarani yang memiliki hubungan persaudaraan yang erat dan saling membantu menyelesaikan masalah dalam masyarakat secara bersama-sama. Budaya Masohi yang menunjukan sikap saling membantu dalam menyelesaikan suatu pekerjaan seperti membangun rumah, rumah adat, membagi beras dan sebagainya. Aspek budaya yang dipaparkan menunjukan adanya hubungan kerja sama yang sangat erat baik individu atau kelompok yang dilakukan dalam menyelesaikan suatu pekerjaan dan ini sangat khas terjadi di Maluku sebab mencerminkan kerukunan beragama. Dengan demikian aspek ini sangat mengena pada prinsip dan karateristik PMRI yang mengedepankan kontribusi siswa dan interaktivitas.

Pada penelitian ini, menggunakan konteks budaya Masohi yaitu membagi beras. Kegiatan membagi beras memiliki aspek keadilan dan menumbuhkan karakter yang jujur pada siswa serta aspek matematis untuk 
mendukung kemampuan siswa dalam memahami materi Perbandingan Senilai melalui strategi yang siswa gunakan. Membagi beras yang dijadikan masalah kontekstual dalam pembelajaran matematika memberikan pengaruh yang positif pada pembelajaran matematika yang lebih bermakna, siswa lebih tertarik untuk menyelesaikan masalah yang ada hubungan dengan kehidupannya dan dapat meningkatkan pemahaman siswa tentang konsep matematika yang dipelajari.

Agar terlaksana pembelajaran yang menggunakan pendekatan PMRI, maka terlebih dahulu peneliti akan membuat serangkaian aktivitas-aktivitas untuk menduga berbagai strategi pemecahan masalah dari kegiatan membagi beras yang dimunculkan dari siswa untuk mengkonstruksi pengetahuan siswa dalam memahami materi Perbandingan Senilai yang dinamakan dengan hypothetical learning trajectory (HLT).

Berdasarkan uraian latar belakang di atas, peneliti tertarik untuk melakukan suatu penelitian pengembangan dengan model design research yang diberi judul "Perangkat Pembelajaran Matematika Menggunakan Pendekatan PMRI Dengan Konteks Budaya Masohi Pada Materi Perbandingan Senilai”, yang meliputi; Rencana Pelaksanaan Pembelajaran (RPP), Lembar Kerja Siswa (LKS), dan InstrumenTes Hasil Belajar (THB).

\section{B. Rumusan Masalah}

Berdasarkan latar belakang masalah di atas, rumusan masalah dalam penelitian ini adalah: 
1. Bagaimana lintasan belajar siswa dalam memahami materi Perbandingan Senilai menggunakan pendekatan PMRI dengan konteks budaya Masohi dapat berkembang dari tahap informal ke tahap formal?

2. Bagaimana proses dan hasil pengembangan pembelajaran matematika yang memenuhi syarat valid, praktis, dan efektif menggunakan pendekatan PMRI dengan konteks budaya Masohi pada materi Perbandingan Senilai?

\section{Tujuan Penelitian}

Berdasarkan rumusan masalah yang dirumuskan, penelitian ini memiliki tujuan sebagai berikut:

1. Menghasilkan lintasan belajar siswa dalam memahami materi Perbandingan Senilai menggunakan pendekatan PMRI dengan konteks budaya Masohi yang berkembang dari tahap informal ke tahap formal.

2. Menghasilkan perangkat pembelajaran matematika yang valid, praktis, dan efektif menggunakan pendekatan PMRI dengan konteks budaya Masohi pada materi Perbandingan Senilai.

\section{Spesifikasi Produk yang Diharapkan}

Produk yang diharapkan dalam penelitian pengembangan dengan model design research pada perangkat pembelajaran menggunakan pendekatan Pembelajaran Matematika Realistik Indonesia adalah sebagai berikut:

1. Rencana Pelaksanaan Pembelajaran (RPP)

2. Lembar Kerja Siswa (LKS)

3. Tes Hasil Belajar (THB) 


\section{E. Manfaat Penelitian}

Hasil penelitian ini diharapkan dapat memberikan manfaat untuk:

1. Siswa, proses pembelajaran dilaksanakan secara menarik dan bermakna diharapkan dapat meningkatkan motivasi pembelajaran pada materi Perbandingan Senilai karena terkait dengan konteks budaya Masohi dimana siswa berasal.

2. Guru, konteks budaya daerah setempat dijadikan sebagai titik awal dalam pembelajaran materi Perbandingan Senilai dan mempunyai cara yang berbeda dalam penyajian pembelajaran.

3. Pembelajaran matematika dengan menggunakan pendekatan PMRI lebih dari sekedar menghitung tetapi menghadirkan masalah konkret dalam kehidupan sehari-hari sebagai titik awal untuk membangun pengembangan ide dan konsep matematika. 


\section{BAB II}

\section{KAJIAN TEORITIK}

\section{A. Pembelajaran Matematika Realistik Indonesia}

Pembelajaran Matematika Realistik Indonesia (PMRI) merupakan suatu pendekatan pembelajaran matematika yang merupakan hasil adaptasi dari RME dikembangkan oleh Institut Freudenthal di Belanda sejak tahun 1971 dan mulai dikenalkan di Indonesia tahun 1998 (Sembiring,2001 dalam Ilma, 2008:9). Pembelajaran matematika realistik dikembangkan berdasarkan pandangan Freudenthal tentang matematika sebagai suatu aktivitas manusia. Ini berarti matematika harus dekat pada siswa dan relevan dengan situasi siswa sehari-hari. PMRI bertitik tolak dari hal-hal yang real bagi siswa dan menekankan pada keterampilan proses, berdiskusi, berkolaborasi, berargumentasi, dan mencari kesimpulan. Ide kunci dari pembelajaran matematika realistik menurut Treffers (1991:25) menekankan perlunya kesempatan bagi siswa untuk menemukan kembali matematika dengan bantuan orang dewasa (guru). Selain itu, pengetahuan matematika formal dapat dikembangkan berdasarkan pengetahuan informal siswa dari proses pengembangan dan ide-ide matematika yang dimulai dari dunia nyata dan dikembalikan lagi ke dunia nyata. Dunia nyata yang dimaksud tidak hanya berarti benda nyata atau lingkungan nyata siswa namun lebih dari itu pemaknaan realistik juga mencakup pengalaman siswa dan pengetahuan yang dimiliki siswa (Gravemeijer,1994:82). 
Dari uraian di atas, dapat dikatakan bahwa PMRI merupakan pendekatan pembelajaran yang bertolak dari masalah-masalah yang sesuai dengan pengalaman siswa. Dalam hal ini, siswa aktif dan guru berperan sebagai fasilitator. Dalam kaitannya dengan matematika sebagai kegiatan manusia, siswa harus diberi kesempatan seluas-luasnya untuk menemukan kembali ide atau konsep matematika secara mandiri sebagai akibat dari pengalaman siswa dalam berinteraksi dengan realitas. Setelah menemukan konsep-konsep matematika, siswa dapat menggunakannya dalam menyelesaikan masalah yang terkait untuk memperkuat kemampuan berpikirnya tentang konsep matematika tersebut.

\section{Prinsip utama PMRI}

Menurut Freudenthal (dikutip Gravemeijer,1994:90) terdapat tiga prinsip pendekatan PMRI, yaitu:

a. Penemuan terbimbing (guided reinvention) dan matematisasi progresif (progressive mathematizing)

Berdasarkan prinsip reinvention, para siswa semestinya diberi kesempatan untuk mengalami proses yang sama dengan proses saat matematika ditemukan. Hal ini dapat dikembangkan dari prosedur penyelesaian informal untuk mengantisipasi prosedur penyelesaian formal. Untuk itu diperlukan masalah kontekstual (contextual problem) yang dapat menyediakan beragam prosedur penyelesaian serta mengindikasikan rute pembelajaran dari tingkat belajar matematik informal ke formal (progressive mathematizing). 
b. Fenomenologi didaktik (didactical phenomenology)

Konsep-konsep yang ada dalam matematika dibuat untuk mengatur fenomena-fenomena yang ada, baik fenomena yang berasal dari kehidupan sehari-hari maupun fenomena yang berasal dari matematika sendiri. Fenomenologi didaktik dari konsep matematika adalah sebuah analisis yang dilakukan pada konsep matematika dan dihubungkan dengan fenomena menarik yang lain. Tantangan dalam prinsip ini yaitu proses menemukan fenomena yang bisa dihubungkan dengan konsep pembelajaran matematika.

c. Pengembangan model sendiri (self-developed models)

Berdasarkan prinsip ini, saat mengerjakan masalah kontekstual siswa diberi kesempatan untuk mengembangkan model mereka sendiri yang berfungsi untuk menjembatani antara pengetahuan informal dan matematika formal. Pada tahap awal siswa mengembangkan model yang dikenalinya. Selanjutnya melalui generalisasi dan pemformalan akhirnya model tersebut menjadi sesuatu nyata yang dimiliki siswa.

\section{Karateristik PMRI}

PMRI memiliki lima karakteristik (Gravemeijer,1994:114) yang merupakan operasionalisasi dari prinsip-prinsip pendekatan PMRI. Karakteristik tersebut antara lain sebagai berikut:

a. Menggunakan masalah kontekstual (the use of context) 
Masalah kontekstual digunakan sebagai peluang aplikasi dan sebagai titik tolak dari mana suatu pembelajaran matematika yang diinginkan dapat muncul. Pada penelitian ini menggunakan konteks beras yang dijadikan masalah kontekstual.

b. Menggunakan model atau jembatan dengan instrumen vertikal (the use of models)

Perhatian diarahkan pada pengenalan model, skema, dan simbolisasi dari pada mentransfer rumus atau matematika formal secara langsung. Istilah model berkaitan dengan situasi dan model matematik yang dikembangkan oleh siswa sendiri. Pengetahuan informal siswa yang diperoleh dari aktivitas yang dilakukan sendiri perlu dikembangkan dalam pengetahuan yang lebih formal dalam pembelajaran Perbandingan Senilai. Aktivitas membagi beras, menulis hasil membagi beras, melakukan konstruksi pengetahuan yang matematis berdasarkan kegiatan membagi beras dengan menggunakan konteks beras yang dijadikan soal cerita dengan tujuan menjembatani siswa dari aktivitas tahap konkret menuju aktivitas pembelajaran materi Perbandingan Senilai sebagai tahap formal.

c. Menggunakan kontribusi siswa (student contributions)

Kontribusi yang besar pada proses pembelajaran diharapkan datang dari konstruksi siswa sendiri yang mengarahkan mereka dari cara-cara informal menuju yang lebih formal. Setiap siswa boleh menggunakan strategi mereka sendiri dalam setiap aktivitas. Dalam 
aktivitas membagi beras, siswa dapat menggunakan berbagai strategi mereka sendiri untuk menemukan hari keberapa persediaan beras akan habis. Pada aktivitas ini ada siswa yang menggunakan strategi dengan menggunakan karung-karung kecil, membuat pemisalan dengan menggambar kotak-kotak kecil, membuat pemisalan dengan menggambar canting beras, menggunakan kalender, atau juga membuat daftar checklist untuk beras yang telah dimasak. Hal ini akan memunculkan bermacam-macam solusi dari masalah yang diberikan. Strategi-strategi dari siswa didiskusikan secara bersama-sama dikelas untuk menguatkan pemahaman materi Perbandingan Senilai.

d. Terjadinya interaktivitas (interactivity)

Adanya interaksi antara guru dengan siswa, antara siswa yang satu dengan yang lainnya atau antara siswa dengan guru. Dalam proses pembelajaran diharapkan terjadi interaksi antara guru dengan siswa. Selain itu diharapkan terjadi pula interaksi antara siswa dengan siswa yaitu dalam mengkontruksi pengetahuannya mereka saling berdisksusi, mengajukan argumentasi dalam menyelasaikan masalah. Jika siswa menemui kesulitan siswa menanyakan kepada guru sehingga terjadi interaksi antara siswa dengan guru. Kerja sama yang dibangun dalam kelompok untuk menemukan hari keberapa persediaan beras akan habis merupakan interaksi sosial antar siswa.

e. Terintegrasi dengan topik pembelajaran lainnya (intertwining) 
Menggunakan teori belajar yang relevan, saling terkait, dan terintegrasi dengan topik pembelajaran lainnya. Aktivitas membagi beras yang dilakukan siswa akan menjadi titik awal mereka dalam mempelajari pengukuran, geometri, pembagian, bilangan pecahan, aljabar, dan perbandingan. Dari hal di atas dapat dikatakan bahwa dalam menyelesaikan masalah kontekstual tersebut membutuhkan berbagai matematika yang saling berkaitan, keterkaitan inilah yang dinamakan intertwining.

Berdasarkan uraian di atas, disimpulkan bahwa pendekatan PMRI memiliki karakteristik tersendiri yang membedakannya dengan pendekatan lain. Dalam pendekatan PMRI, matematika tidak dipandang sebagai produk jadi yang langsung disampaikan dalam bentuk rumus-rumus, melainkan melalui proses penemuan konsep dalam kegiatan memecahkan masalah kontekstual yang diberikan oleh guru.

\section{Langkah-langkah PMRI}

Berdasarkan pada prinsip dan karakteristik PMRI, maka langkahlangkah pembelajaran matematika dengan pendekatan PMRI dalam penelitian ini sebagai berikut:

\section{Langkah 1: memahami masalah kontekstual}

Guru memberikan masalah kontekstual sesuai dengan materi pelajaran yang sedang dipelajari siswa. Kemudian siswa diminta untuk memahami masalah kontekstual tersebut. Guru menjelaskan dan memberikan petunjuk seperlunya kepada siswa jika terdapat hal-hal yang belum atau kurang 
dipahaminya. Karateristik pendekatan PMRI yang muncul pada langkah ini yaitu guru menggunakan masalah kontekstual yang diberikan sebagai masalah awal atau titik awal (starting point) dalam pembelajaran.

\section{Langkah 2: menyelesaikan masalah kontekstual}

Siswa diminta untuk menyelesaikan masalah kontekstual pada LKS secara kelompok sehingga dimungkinkan adanya perbedaan prosedur penyelesaian. Sementara siswa menyelesaikan masalah, guru mengamati dan mengontrol aktivitas siswa. Pada langkah ini karakteristik pendekatan PMRI yang muncul adalah menggunakan model.

\section{Langkah 3: membandingkan dan mendiskusikan jawaban}

Siswa diberikan waktu dan kesempatan oleh guru untuk membandingkan dan mendiskusikan jawaban dari masalah dengan teman sekelompoknya. Selanjutnya jawaban dari masalah dengan teman sekelompoknya dibandingkan dan didiskusikan pada diskusi kelas. Karakteristik pendekatan PMRI yang muncul pada langkah ini adalah penggunaan kontribusi siswa dan terdapat interaksi antara siswa yang satu dengan siswa yang lain.

\section{Langkah 4: menyimpulkan}

Siswa diarahkan oleh guru untuk mengambil kesimpulan dari hasil diskusi kelas sehingga diperoleh suatu rumusan konsep atau prinsip atau prosedur. Karakteristik pendekatan PMRI yang muncul pada langkah ini adalah terdapat interaksi antara siswa dengan guru.

\section{B. Pembelajaran Matematika Berbasis Konteks Budaya Maluku}


Proses pembelajaran matematika harus dimulai dengan permasalahan yang kontekstual agar siswa merasa bahwa materi yang dipelajarinya dalam matematika merupakan bagian dari dirinya yang tidak datang secara tiba-tiba. Memasukan materi tentang kebudayaan ke dalam pembelajaran matematika merupakan bagian dari upaya tersebut. Hal ini sangat beralasan karena pembelajaran berbasis budaya menjadikan pembelajaran bermakna kontekstual yang terkait dengan komunitas budaya dan pembelajaran berbasis budaya menjadikan pembelajaran menarik dan menyenangkan. Begitu juga pada Kurikulum 2006 dan Kurikulum 2013 yang menonjolkan peningkatan kemampuan siswa terhadap budaya dan pembelajaran yang berpusat pada siswa.

Pembelajaran matematika dengan menggunakan konteks budaya pada penelitian ini menggunakan konsep ethnomathematics. Etnomatematika pertama kali dicetuskan dan dikembangkan oleh seorang matematikawan Brasil yaitu Ubiratan D'Ambrosio. Menurut D'Ambrosio 1984 (dikutip Laurens 2016:2), etnomatematika adalah suatu studi tentang pola hidup, kebiasaan atau adat istiadat dari suatu masyarakat di suatu tempat yang memiliki kaitan dengan konsep-konsep matematika namun tidak disadari sebagai bagian dari matematika oleh masyarakat tersebut. Sejak pertama kali dicetuskan hingga saat ini, etnomatematika telah berkembang di berbagai belahan dunia dan mengalami kemajuan pesat karena memberi pengaruh positif bagi perkembangan budaya dan pendidikan matematika. 
Menyikapi peranan etnomatematika untuk melestarikan kebudayaan di berbagai belahan dunia dan kondisi real dari eksistensi kebudayaan, khususnya di Maluku yang perlahan-lahan mulai terancam oleh kemajuan IPTEK dapat dilestarikan melalui pembelajaran matematika dengan konsep etnomatematika. Berikut ini implementasi nyata (Laurens,2016:8) yang dapat dilakukan dalam pembelajaran matematika dengan etnomatematika di Maluku antara lain yaitu:

1. Mengenalkan rumah adat Baileo yang merupakan warisan masa lampau dan mengaitkannya dengan konsep bangun-bangun geometri pada siswa di sekolah.

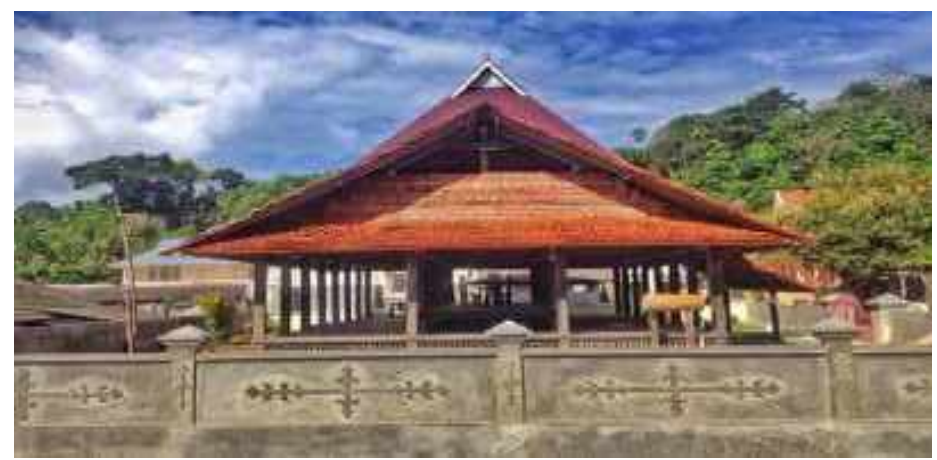

Gambar 1. Rumah Adat Baileo di Desa Allang

2. Budaya Cuci Negri dan membangun rumah adat yang mengedepankan nilai-nilai kerja sama dalam kelompok.

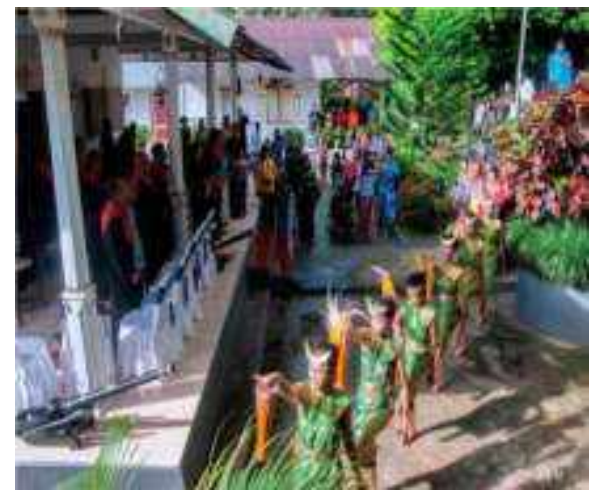

(a)

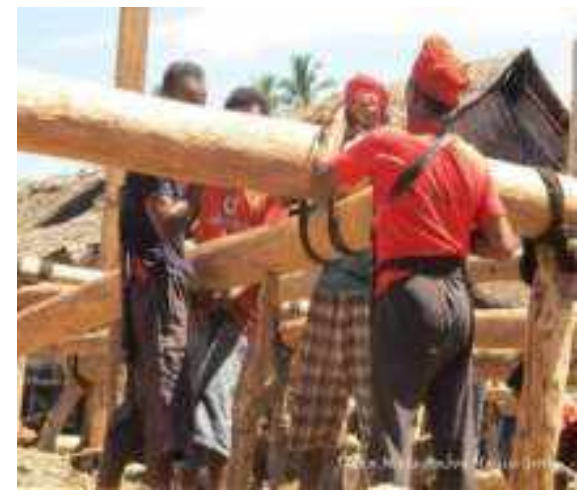

(b) 
Gambar 2. Budaya Cuci Negeri Desa Soya (a) dan Membangun Baileo oleh Suku Nuaulu (b)

3. Budaya Masohi membagi beras yang dijadikan masalah kontekstual dapat dimasukan dalam pembelajaran perbandingan senilai.

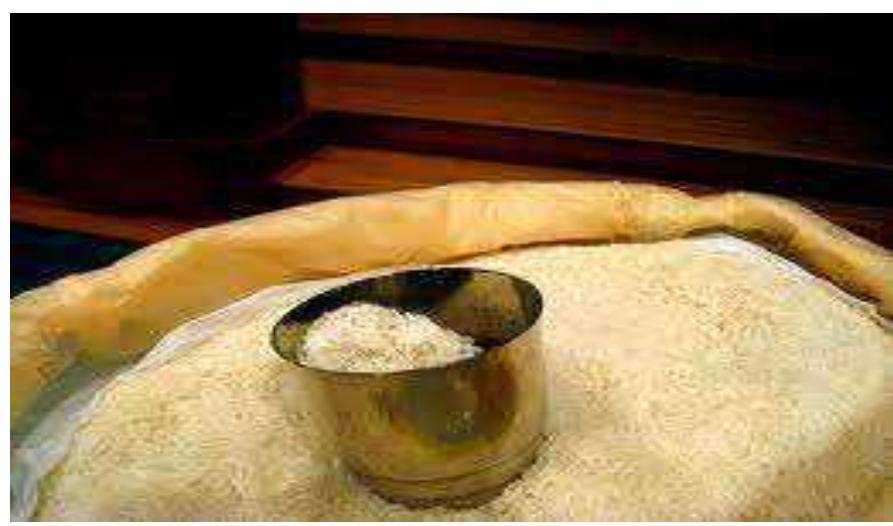

Gambar 3. Budaya Masohi Membagi Beras

4. Corak kain tenun dari wilayah Maluku Tenggara Barat. Hasil tenunan diperoleh dari kemampuan mental aritmatika dalam menghitung banyaknya benang yang digunakan serta kemampuan spasial dalam membentuk bangun yang simetris.

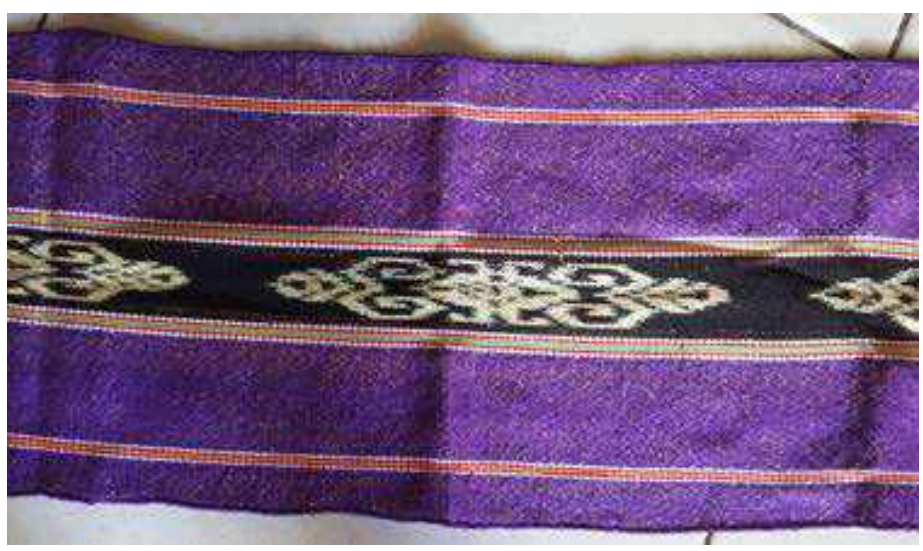

Gambar 4. Kain Tenun Maluku Tenggara Barat

5. Budaya Pela dan Gandong dikepulauan Maluku dapat dijadikan titik awal pembelajaran (starting point) dalam memahami konsep relasi dan fungsi. 


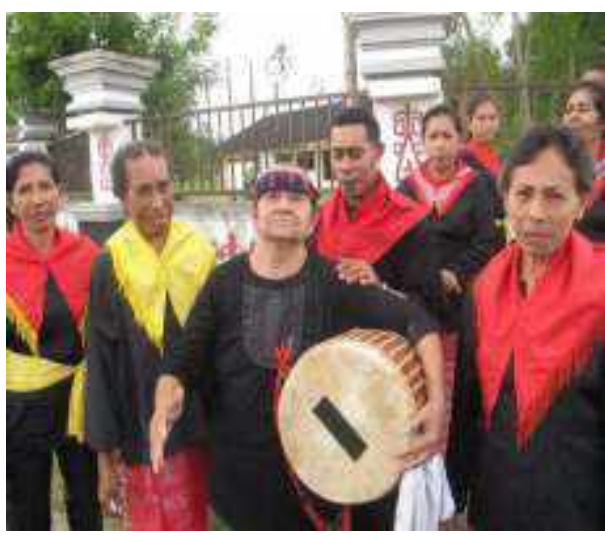

(a)

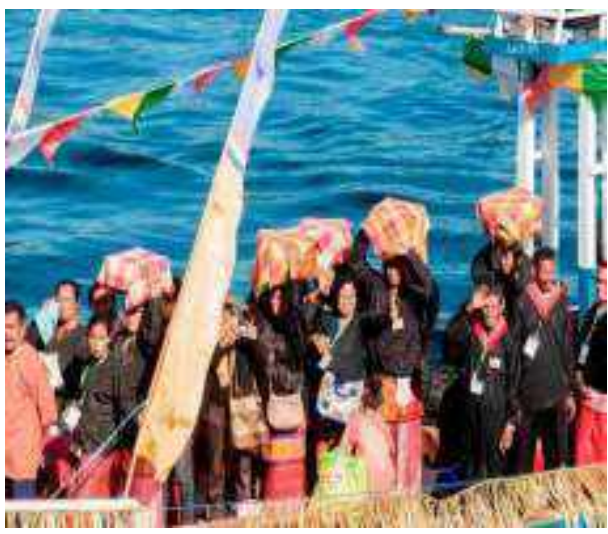

(b)

\section{Gambar 5. Panas Pela Rumah 3, Wakal \& Hitumesing (a) dan Panas Gandong Rutong-Rumahkay (b)}

Memasukan materi budaya Maluku dapat menjadi pembelajaran matematika realistik yang diharapkan mampu menjadi pembelajaran yang bermakna terkait dengan komunitas budaya dimana siswa berasal dan membantu siswa untuk menunjukan atau mengekspresikan keterkaitan konsep matematika yang dipelajarinya dengan budaya komunitasnya. Pada penelitian ini konteks yang digunakan adalah budaya Masohi membagi beras. Oleh karena itu tepat sekali jika dalam mengajarkan matematika formal (matematika sekolah), guru sebaiknya memulai dengan matematika informal yang diterapkan oleh siswa dalam kehidupan sehari-hari. Akibatnya pembelajaran menjadi menarik dan menyenangkan karena terjadinya penciptaaan makna secara kontekstual berdasarkan pengalaman awal siswa sebagai seorang anggota suatu masyarakat budaya.

\section{Pengembangan Model Kepada Pengetahuan Matematika Formal}

Penerapan karakteristik kedua dari PMRI adalah melibatkan proses pengembangan model. Pada proses tersebut, siswa secara mandiri akan 
mengkonstruk model dari yang bersifat konkret menjadi abstrak. Model tersebut sebagai jembatan yang menghubungkan antara masalah konstektual, matematika informal, dan matematika formal. Oleh karena itu, model mempunyai peranan penting dalam proses penyelesaian masalah dan penemuan konsep. Pada penelitian ini, akan menghasilkan serangkaian dugaan dan juga strategi dari aktivitas-aktivitas siswa untuk mendukung pemahaman dalam pembelajaran materi Perbandingan Senilai. Proses dari membagi beras setiap hari untuk menemukan hari keberapa persediaan beras akan habis sampai dengan menuliskan hasil membagi beras secara adil dalam bentuk tabel serta penggunaan rumus formal pada Perbandingan Senilai yang berpusat pada perubahan aktivitas kegiatan dan perkembangan matematika dikenal dengan pengembangan model.

Pengembangan model yang digambarkan oleh Gravemeijer (1994:101) menujukan suatu proses perubahan dari model untuk situasi tertentu (modelof) menjadi situasi yang lebih formal (model-for). Tahap-tahap dalam pengembangan model dari tahap situasional (konkret) ke tahap formal ditunjukkan pada gambar di bawah ini.

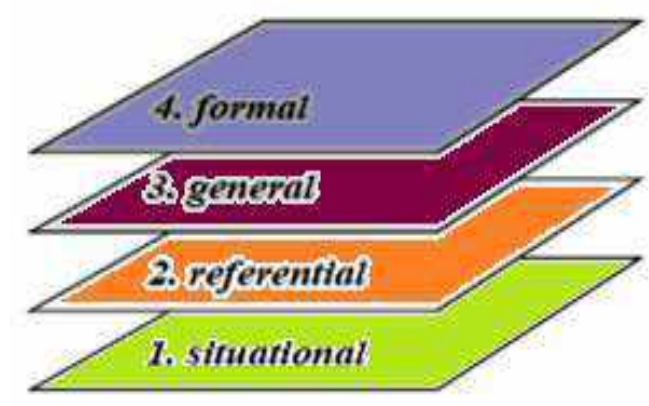

Gambar 6. Tahap-tahap dalam Pengembangan Model 
Implementasi dari tahap-tahap dalam pengembangan model dalam penelitian ini dijelaskan sebagai berikut:

\section{1) Tahap situational/contextual problem}

Tahap situational/contextual problem adalah tahap dasar dari pengembangan model. Pada tahap ini masalah yang mengacu ke topik sudah ditentukan dan pengetahuan tentang situasi yang ada dalam konteks digunakan untuk penyelesaian masalah dengan menggunakan strategi siswa sendiri.

2) Tahap referential

Tahap penggunaan model dan berbagai strategi digunakan untuk menyelesaikan permasalahan yang ada dalam tahap referential disebut dengan tahap model-of. Diskusi kelas akan mendorong siswa untuk mampu berpindah dari tahap situasional ke tahap referential.

3) Tahap general

Pada tahap general muncul mode-for dan strategi-strategi yang biasa digunakan untuk menyelesaikan permasalahan baik dengan konteks yang sama maupun berbeda dengan konteks yang dipakai pada tahap situasional dan referential.

4) Tahap formal

Pada tahap formal, proses penyelesaian masalah dilakukan dengan menggunakan simbol atau rumus-rumus formal dan tidak lagi tergantung pada penggunaan aktivitas dalam model-of. 
Moerland (Sugiman,2011:8) menyatakan bahwa memvisualisasikan proses matematisasi dalam pembelajaran matematika realistik sebagai proses pembentukan gunung es (iceberg) yang mengapung di laut. Sama persisnya dengan pengembangan model yang dilakukan oleh Gravemeijer (1994:101) sebelumnya, proses pembentukan gunung es juga terdiri dari empat tingkatan aktivitas yaitu: situational/contextual problem, model-of, model-for, dan formal mathematics. Gunung es terbentuk mula-mula dari dasar laut, kemudian semakin ke atas, dan sampailah pada pembentukan puncaknya yang terlihat di atas permukaan laut. Seperti gunung-gunung pada umumnya, bagian dasar gunung es yang paling dasar tentunya memiliki daerah atau wilayah yang lebih luas dibandingkan dengan bagian atasnya. Sedangkan matematika yang diajarkan pada sekolah saat ini hanya matematika yang tampak di atas permukaan air laut saja dalam gunung es tersebut, yaitu matematika formal. Padahal masih banyak tahap yang ada dibawahnya sangat mempengaruhi kekokohan pengetahuan yang akan dibangun.Visualisasi dari proses matematisasi ini digambarkan sebagai berikut.

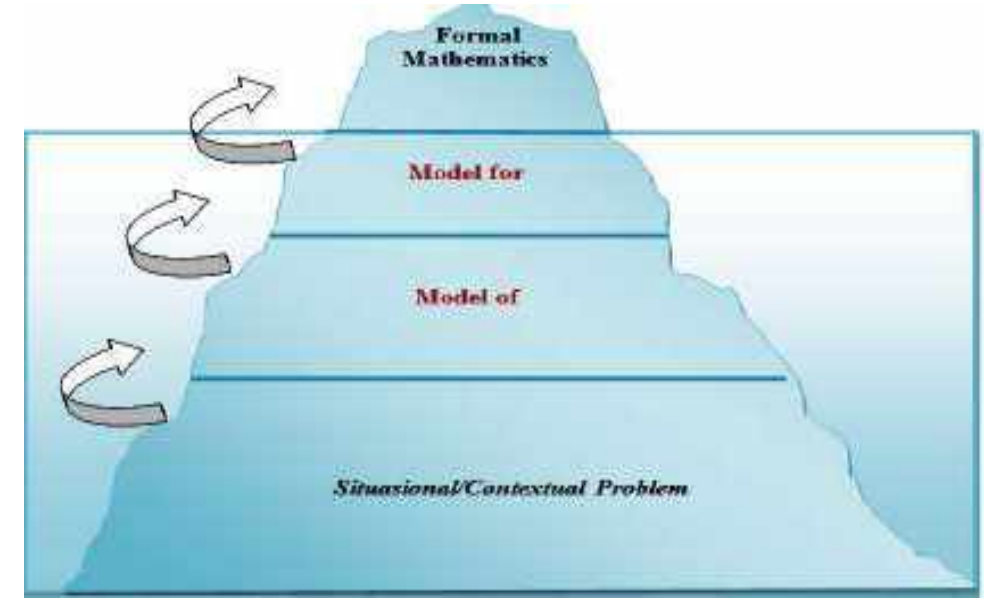

Gambar 7. Iceberg Pendekatan PMRI 
Untuk membangun pengetahuan matematika siswa maka pertama yang harus dibangun adalah dengan hal-hal yang konkret, yang ada didalam kehidupan siswa sehari-hari. Harus dipastikan bahwa tahap ini terbangun dengan kokoh, dan dilanjutkan dengan tahap selanjutnya. Hal ini diadopsi pula untuk pendekatan PMRI, dimana pengetahuan matematika dibangun dari hal-hal yang konkret, kemudian model konkret, model formal baru terakhir ke matematika formal.

\section{Desain Soal Kontekstual Melalui Pendekatan PMRI}

Desain diterjemahkan secara bebas sebagai proses perencanaan untuk membuat dan menciptakan objek baru. Dalam kaitannya dengan pendekatan PMRI, desain soal kontekstual yang dibuat berguna untuk pembentukan konsep, model, akses dan motivasi terhadap pembelajaran matematika.

Karakteristik pertama PMRI yaitu menggunakan masalah kontekstual (the use of contexts), penggunaan konteks sebagai titik awal bagi siswa dan sekaligus menggunakan konteks tersebut sebagai sumber aplikasi matematika. Soal kontesktual matematika merupakan soal-soal matematika yang menggunakan berbagai konteks sehingga menghadirkan situasi yang pernah dialami secara real oleh siswa (Zulkardi dan Ilma,2006:1). Pada soal tersebut, konteks harus sesuai dengan matematika yang sedang dipelajari. Konteks itu sendiri dapat diartikan dengan situasi, fenomena atau kejadian alam yang terkait dengan matematika yang sedang dipelajari. Konteks atau situasi dalam pembelajaran matematika dengan menggunakan pendekatan 
PMRI ini menurut de Lange (Zulkardi dan Ilma, 2006:2) terbagi atas empat bagian yaitu:

1) Personal siswa, situasi ini berkaitan dengan kehidupan sehari-hari dari siswa baik di rumah, dengan teman sepermainan, teman sekelas dan kesenangannya. Contoh permainan gasing tradisional yang dimainkan anak-anak pada waktu istirahat di sekolah. Permainan ini akan membawa siswa mengalami aktivitas pengukuran waktu secara filosifis dan historis. Kepekaan siswa terhadap waktu akan diuji ketika siswa menentukan pemenang dari suatu pertandingan gasing.

2) Akademik, situasi ini berkaitan dengan kehidupan akademik siswa, di ruang kelas, dan kegiatan-kegiatan yang terkait dengan proses pembelajaran misalnya membaca cerita rakyat. Cerita rakyat merupakan konteks yang berhubungan dengan sekolah siswa. Cerita rakyat merupakan salah satu topik yang terdapat pada mata pelajaran bahasa Indonesia yang diajarkan di sekolah dengan tujuan untuk mendidik siswa melalui bermacam-macam karakter. Siswa akan mengetahui bahwa karakter yang buruk akan membawa kepada kesusahan dan penyesalan sedangkan karakter yang baik akan membawa kepada kebahagiaan. Pada pelajaran matematika, cerita rakyat ini bisa dijadikan konteks bagi siswa untuk belajar matematika. Salah satu cerita rakyat yang mengandung matematika adalah Legenda Pulau Kemaro. Cerita ini bisa dijadikan konteks yang menarik untuk belajar Statistika. 
3) Public/masyarakat, situasi ini terkait dengan kehidupan dan aktivitas masyarakat sekitar siswa tersebut tinggal. Misalnya budaya Masohi membagi beras yang ada di Maluku. Budaya ini menjelaskan bagaimana melakukan kerja sama untuk membagi berasa secara adil setiap hari. Dari informasi yng diperoleh ternyata aktivitas budaya yang dilakukan mengandung matematika. Sehingga pada pembelajaran matematika, bentuk aktivitas tadi ternyata dapat dibuat dalam bentuk soal cerita yang menarik dan menyenangkan. Bentuk soal cerita membagi beras bisa dijadikan konteks yang menarik untuk belajar materi Perbandingan Senilai.

4) Scientific, situasi ini berkaitan dengan fenomena dan substansi secara saintifik atau berkaitan dengan matematika itu sendiri.

Tujuan penggunaan konteks adalah menopang terlaksananya proses penemuan terbimbing (guided reinvention) dalam pembentukan model, aplikasi, \& mempraktekkan kemampuan tertentu. Penggunaan konteks dapat juga memudahkan siswa untuk mengenali masalah sebelum memecahkannya.

\section{E. Dugaan Lintasan Belajar Siswa}

Dugaan lintasan belajar siswa (hypothetical learning trajectory) merupakan lintasan belajar yang dibuat oleh guru (peneliti) yang didasari pada pemikiran untuk memilih desain pembelajaran khusus, sehingga pembelajaran dapat dipahami oleh siswa. Simon (Bardsley,2006:14) pertama kali memperkenalkan HLT yang terdiri atas tiga kompenen utama yaitu:

1) Tujuan pembelajaran (learning goals) 
Tujuan yang dimaksud disini adalah apa yang akan dicapai siswa dalam kegiatan pembelajaran tersebut.

2) Aktivitas pembelajaran (learning activities)

Aktifitas pembelajaran yang dirancang dengan saksama agar tujuan pembelajaran dapat tercapai.

3) Dugaan proses belajar siswa (hypothetical learning process)

Peneliti menduga diawal tentang bagaimana kegiatan pembelajaran akan berlangsung dan utamanya adalah proses belajar siswa selama kegiatan tersebut. Dengan dugaan-dugaan ini, peneliti dapat mengantisipasi segala kemungkinan di kelas.

Pentingnya HLT dianalogikan dengan perencanaan rute perjalanan. Jika kita memahami rute-rute yang mungkin untuk menuju tujuan, maka bisa memilih rute yang mungkin untuk mencapai tujuan (Wijaya,2009:374). HLT digunakan sebagai instrumen yang menjadi panduan pada proses pelaksanaan penelitian pengembangan dengan model design research, sebagai perluasan dari percobaan pikiran (tought experiment). Selama tahap preliminary dan teaching experiment sehingga menghasilkan lintasan pembelajaran (learning trajectory) yang berkembang dari tahap informal ke tahap formal.

\section{F. Perangkat Pembelajaran Matematika}

Perangkat pembelajaran adalah sekumpulan sumber belajar yang memungkinkan siswa dan guru melakukan kegiatan pembelajaran. Ibrahim (2002:3) menyatakan bahwa ibarat pasukan yang akan berperang memerlukan logistik, seorang guru yang akan "bertempur" didalam kelaspun memerlukan 
sejumlah piranti atau perangkat pembelajaran yang akan membantu dan memudahkan proses pembelajaraan dan memberikan pengalaman kepada siswa dalam rangka mencapai tujuan yang sudah ditentukan.

Sehubungan dengan hal tersebut Usman (2001:11) menyatakan perangkat pembelajaran merupakan prasyarat bagi terjadinya interaksi belajar mengajar yang optimal. Jadi jelas bahwa perangkat pembelajaran akan mempengaruhi keberhasilan proses pembelajaran di kelas. Oleh sebab itu perangkat pembelajaran mutlak diperlukan oleh seorang guru dalam mengelola pembelajaran.

Dalam implementasinya perangkat pembelajaran terdiri dari berbagai komponen tergantung kepada kebutuhan masing-masing orang (guru). Namun dalam penelitian ini, perangkat pembelajaran yang dimaksud adalah: Rencana Pelaksanaan Pembelajaran (RPP), Lembar Kerja Siswa (LKS) dan Tes Hasil Belajar (THB) yang memuat langkah-langkah pembelajaran menggunakan pendekatan PMRI. Perangkat pembelajaran yang akan dikembangkan pada penelitian ini dapat jelaskan sebagai berikut:

\section{Rencana Pelaksanaan Pembelajaran (RPP)}

Rencana Pelaksanaan Pembelajaran adalah suatu rencana yang berisi prosedur atau langkah-langkah kegiatan guru dan siswa yang disusun secara sistematis sebagai pedoman bagi guru dalam melaksanakan proses pembelajaran di kelas. Makin baik perencanaan yang dibuat, makin mudah pelaksanaan kegiatan pembelajaran sehingga semakin tinggi kemungkinan hasil belajar 
yang dicapai (Usman,2001:43). Pada penelitian ini dikembangkan rencana pembelajaran yang terdiri dari bagian pendahuluan, kegiatan inti, dan penutup yang didalamnya memuat langkahlangkah pembelajaran sesuai pendekatan PMRI.

\section{Lembar Kerja Siswa (LKS)}

Mengingat tingkat kemampuan siswa yang berbeda, maka perangkat ini perlu dilengkapi dengan Lembar Kerja Siswa. Keberadaan LKS ini dimaksudkan untuk memberikan kemudahan pada guru dalam mengakomodir tingkat kemampuan siswa yang berbeda, disamping memberi kemudahan bagi guru untuk mengelolah pembelajaran menggunakan pendekatan PMRI.

\section{Tes Hasil Belajar (THB)}

Perangkat pembelajaran juga dilengkapi dengan alat evaluasi berupa tes hasil belajar yang dapat digunakan untuk mengukur ketuntasan belajar siswa pada materi perbandingan senilai. Tes hasil belajar dibuat sesuai dengan pendekatan PMRI. Dalam menyusun tes hasil belajar, hal-hal yang perlu diperhatikan adalah:

a. Materi

1) Soal sesuai dengan indikator atau tujuan pembelajaran;

2) Batasan pertanyaan yang akan diukur sudah jelas;

3) Isi materi yang ditanyakan sesuai dengan tujuan pengukuran;

4) Isi materi yang ditanyakan sesuai dengan jenis sekolah dan tingkat kelas. 
b. Kontruksi

1) Pertanyaan butir soal menggunakan kata tanya atau perintah yang menuntut jawaban terurai atau melengkapi;

2) Rumusan butir soal tidak menimbulkan penafsiran ganda;

c. Bahasa

1) Rumusan butir soal menggunakan bahasa yang sederhana dan mudah dipahami;

2) Rumusan butir soal menggunakan bahasa Indonesia yang baik.

Dalam merancang perangkat pembelajaran, perlu diperhatikan validitas rancangan. O'Meara dikutip (Sabardin (2004:40) menyatakan bahwa validitas perangkat secara umum dapat ditinjau dari 4 hal, yaitu: 1) format, 2) bahasa, 3) ilustrasi, dan 4) isi. Keempat hal di atas tidak selalu dimunculkan dalam tiap perangkat dan harus disesuaikan dengan karakteristik masing-masing perangkat.

a. Indikator format meliputi komponen-komponen:

1) Kejelasan pembagian materi;

2) Sistem penomoran jelas dan menarik;

3) Kesesuaian antara teks dan ilustrasi;

4) Pengaturan ruang;

5) Kesesuaian jenis dan ukuran huruf.

b. Indikator bahasa meliputi komponen-komponen:

1) Kebenaran tata bahasa;

2) Kesesuaian kalimat dengan tingkat perkembangan siswa; 
3) Arahan untuk membaca sumber lain;

4) Kesederhanaan struktur kalimat;

5) Kejelasan petunjuk dan arahan.

c. Indikator ilustrasi meliputi komponen-komponen:

1) Dukungan ilustrasi untuk memperjelas konsep;

2) Keterkaitan secara langsung dengan konsep yang dibahas;

3) Kejelasan;

4) Kemudahan untuk dipahami;

5) Penggunaan konteks lokal.

d. Indikator isi perangkat pembelajaran meliputi komponen-komponen:

1) Kebenaran isi;

2) Bagian-bagian tersusun secara logis;

3) Merupakan materi yang esensial;

4) Kesesuaian dengan garis besar program pembelajaran;

5) Kesesuaian dengan pola pikir siswa;

6) Memuat latihan yang berhubungan dengan konsep yang ditemukan;

7) Kesesuaian dengan pendekatan pembelajaran yang dipilih;

8) Berhubungan dengan materi sebelumnya. 


\section{G. Keefektifan Pembelajaran}

Pembelajaran dapat dikatakan efektif apabila siswa secara aktif dilibatkan dalam mengorganisasikan dan menemukan hubungan-hubungan informasi yang diberikan. Siswa tidak hanya menerima secara pasif pengetahuan yang disampaikan oleh guru tetapi mereka dapat memberikan tangggapan secara aktif. Hasil dari aktivitas ini tidak hanya meningkatkan pemahaman dan daya serap siswa pada materi pembelajaran, tetapi juga melibatkan ketrampilan berpikir. Menurut Slavin (1997:307), kefektifan pembelajaran terdiri dari empat indikator, yaitu kualias pembelajaran (quality of instruction), kesesuaian tingkat pembelajaran (appropriate level of instruction), insentif (incentive), dan waktu (time).

1. Kualitas pembelajaran yang dimaksudkan ialah derajat informasi atau keterampilan yang disajikan sehingga siswa dapat mempelajarinya dengan mudah. Hal ini tentunya siswa berada pada tingkat kesalahan yang kecil. Semakin kecil tingkat kesalahan yang dilakukan berarti makin efektif pembelajaran.

2. Kesesuaian tingkat pembelajaran adalah guru memastikan tingkat kesiapan siswa dalam keterampilan dan pengetahuan untuk mempelajari materi baru. Dengan kata lain, materi pembelajaran yang diberikan tidak terlalu sulit atau tidak terlalu mudah.

3. Insentif adalah guru memotivasi siswa untuk mengerjakan tugastugas yang diberikan guru kepada siswa. Semakin besar motivasi yang diberikan, keaktifan siswa makin besar pula. Dengan 
demikian, pembelajaran akan efektif.

4. Waktu adalah lamanya waktu yang diberikan kepada siswa untuk mempelajari materi yang disajikan. Pembelajaran akan efektif jika siswa dapat menyelesaikan pelajaran sesuai dengan waktu yang ditentukan.

Diamond dikutip (Mudhofir,1987:164), keefektifan dapat diukur dengan melihat minat siswa terhadap kegiatan pembelajaran. Suherman (1986:78) menyatakan minat mempengaruhi proses hasil belajar siswa.

Eggen (1988:1) mengatakan bahwa pembelajaran dikatakan efektif apabila siswa secara aktif dilibatkan dalam pengorganisasian dan penemuan informasi (pengetahuan). Siswa tidak hanya menerima pengetahuan yang diberikan guru. Tetapi keterlibatan siswa dalam pengorganisasian pelajaran dan pengetahuannya perlu diperhatikan. Semakin aktif siswa maka ketercapaian ketuntasan pembelajaran semakin besar, sehingga semakin efektiflah pembelajaran.

Kemp dikutip (Mudhofir,1987:164) mengemukakan cara untuk mengukur keefektifan pembelajaran yaitu dengan mengajukan suatu pertanyaan, “Apakah yang telah dicapai siswa?” Untuk menjawab pertanyaan ini harus diketahui berapa banyak jumlah siswa yang berhasil mencapai tujuan belajar dalam waktu yang telah ditentukan. Cara ini sejalan dengan indikator keefektifan pembelajaran yang dikemukakan Slavin (1997:307), yaitu indikator kualitas pembelajaran.

Berdasarkan pendapat di atas maka dalam penelitian ini yang dimaksud 
dengan keefektifan pembelajaran dalam penelitian ini adalah ukuran keberhasilan suatu pembelajaran. Pencapaian keefektifan pembelajaran didasarkan pada 4 aspek yaitu: ketuntasan hasil belajar siswa (merujuk pada pendapat Kemp), aktivitas siswa dalam pembelajaran (merujuk pada pendapat Eggen), kemampuan guru dalam mengelola pembelajaran (merujuk pada pendapat Slavin), dan respon siswa terhadap pembelajaran (merujuk pada pendapat Suherman).

\section{H. Materi Perbandingan Senilai}

\section{Perbandingan}

a. Pengertian perbandingan

Pada dasarnya perbandingan merupakan penyederhanaan bentuk pecahan yaitu $\frac{a}{b}$ atau a : b dibaca a berbanding $\mathrm{b}$, dengan a dan $\mathrm{b}$ merupakan bilangan positif. Penulisan bentuk perbandingan sama dengan penulisan bentuk suatu pecahan, yaitu dinyatakan dalam bentuk $\frac{a}{b}$. Bentuk $\frac{a}{b}$ dalam perbandingan artinya membandingkan suatu besaran atau bilangan dengan besaran lainnya.

Membandingkan dua obyek diartikan dua hal. Pertama, membandingkan dapat diartikan sebagai selisih ukurannnya. Kedua, membandingkan dapat diartikan sebagai mencari nilai perbandingan antara ukuran dari kedua obyek itu.

Contoh perbandingan dalam kehidupan sehari-hari misalnya tinggi badan Amir $160 \mathrm{~cm}$ sedangkan tingggi badan Budi $170 \mathrm{~cm}$. 
perbandingan tinggi badan Ami dan tinggi badan Budi dapat dinyatakan dengan dua cara yaitu:

1. Tinggi badan Amir kurang dari tinggi badan Budi. Dalam hal ini, yang dibandingkan adalah selisih tinggi badan.

2. Tinggi badan Amir : tinggi badan Budi $=160 \mathrm{~cm}: 170 \mathrm{~cm}$.

$$
160: 170=16: 17=\frac{16}{17}
$$

Berdasarkan contoh di atas dapat disimpulkan bahwa ada dua cara dalam membandingkan dua besaran yaitu dengan mencari selisih dan mencari hasil bagi.

b. Menyederhanakan perbandingan dua besaran sejenis

Dalam menyederhanakan perbandingan dengan dua besaran sejenis, digunakan cara yang sama dalam menyederhanakan Pecahan. Suatu perbandingan dikatakan dalam bentuk yang sederhana jika masing-masing besaran atau bilangan yang dibandingkan tidak mempunyai faktor pesekutuan. Untuk dua besaran sejenis a dan $b$ dengan m adalah FPB dari a dan b maka:

$$
\frac{a}{b}=\frac{a: m}{b: m}, \text { dimana } \mathrm{b} \neq 0
$$

Contoh:

Sebuah meja berukuran $150 \mathrm{~cm}$ dan lebar $100 \mathrm{~cm}$. Perbandingan panjang dan lebar meja dapat dilakukan dengan dua cara, yaitu dengan mencari selisihnya, $150 \mathrm{~cm}-100 \mathrm{~cm}=50 \mathrm{~cm}$ atau dapat pula dengan mencari hasil baginya, yaitu $150: 100=3: 2$. Panjang dan lebar meja adalah dua besaran sejenis, karena mempunyai satuan yang sama, 
yaitu cm. Namun, panjang meja dan luas meja adalah dua besaran tidak sejenis, karena mempunyai satuan yang berbeda sehingga tidak dapat dibandingkan. Pada materi ini, kita akan membandingkan dua besaran sejenis dengan cara mencari hasil bagi.

\section{Perbandingan senilai}

Misalkan terdapat dua besaran $\mathrm{A}=\left\{a_{1}, a_{2}, a_{3}, \ldots, a_{n}\right\}$ dan $\mathrm{B}=$ $\left\{b_{1}, b_{2}, b_{3}, \ldots, b_{n}\right\}$ yang berkorespondensi satu-satu, maka A dan B disebut berbanding senilai. Perbandingan Senilai terjadi jika untuk ukuran A semakin besar/kecil sejalan dengan ukuran B yang semakin semakin besar/kecil juga. Berikut ini merupakan tabel Perbandingan Senilai.

\begin{tabular}{|c|c|}
\hline $\mathbf{A}$ & $\mathbf{B}$ \\
\hline$a_{1}$ & $b_{1}$ \\
\hline$a_{2}$ & $b_{2}$ \\
\hline$a_{3}$ & $b_{3}$ \\
\hline$\ldots$ & $\ldots$ \\
\hline$a_{n}$ & $b_{n}$ \\
\hline \multicolumn{2}{|c|}{$\frac{a_{1}}{a_{2}}=\frac{b_{1}}{b_{2}}$} \\
\hline
\end{tabular}

Tabel 1. Perbandingan Senilai

Pada materi Perbandingan Senilai bentuk $\frac{\boldsymbol{a}_{1}}{\boldsymbol{a}_{2}}=\frac{\boldsymbol{b}_{1}}{\boldsymbol{b}_{2}}$ dapat diubah menjadi bentuk perkalian $a_{1} x b_{2}=a_{2} x b_{1}$ dengan melakukan perkalian silang. Grafik Perbandingan Senilai berupa garis lurus, jika absis bertambah maka ordinat juga bertambah. Berikut ini merupakan gambar grafik Perbandingan Senilai.

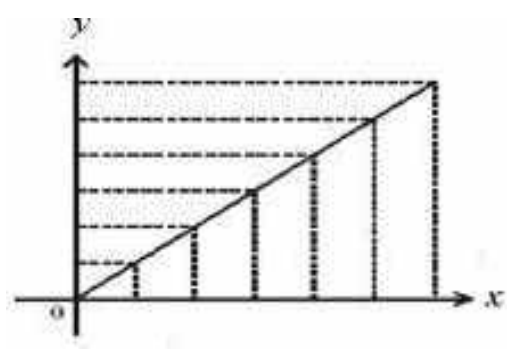




\section{Gambar 8. Grafik Perbandingan Senilai}

\section{Kurikulum 2013 Pembelajaran Perbandingan Senilai}

Pada kurikulum 2013, Perbandingan Senilai diajarkan pada siswa kelas

VII SMP dengan rincian pembelajarannya pada tabel di bawah ini.

Tabel 2. Kurikulum Pembelajaran Perbandingan Senilai

\begin{tabular}{|c|c|c|}
\hline \multicolumn{2}{|r|}{ Kompetensi Inti } & Kompetensi Dasar \\
\hline KI 1 & $\begin{array}{l}\text { Menghargai dan menghayati } \\
\text { ajaran agama yang dianut. }\end{array}$ & $\begin{array}{l}\text { 1. Menghargai dan menghayati ajaran } \\
\text { agama yang dianutnya. }\end{array}$ \\
\hline KI 2 & $\begin{array}{l}\text { Menghargai dan menghayati } \\
\text { perilaku jujur, disiplin, } \\
\text { tanggungjawab, peduli } \\
\text { (toleransi, gotong royong), } \\
\text { santun, percaya diri, dalam } \\
\text { berinteraksi secara efektif } \\
\text { dengan lingkungan sosial } \\
\text { dan alam dalam jangkauan } \\
\text { pergaulan dan } \\
\text { keberadaannya. }\end{array}$ & $\begin{array}{l}\text { 2. Memiliki rasaingin tahu, percaya diri, } \\
\text { dan ketertarikan pada matematika } \\
\text { serta memiliki rasa percaya pada daya } \\
\text { dan kegunaan matematika yang } \\
\text { terbentuk melalui pengalaman } \\
\text { belajar. } \\
\text { 3. Memahami konsep perbandingan dan } \\
\text { menggunakan bahasa perbandingan } \\
\text { dalam mendeskripsikan hubungan } \\
\text { dua besaran atau lebih. }\end{array}$ \\
\hline KI 3 & $\begin{array}{l}\text { Memahami pengetahuan } \\
\text { (faktual, konseptual, dan } \\
\text { prosedural) berdasarkan rasa } \\
\text { ingin tahunya tentang ilmu } \\
\text { pengetahuan, teknologi, } \\
\text { seni, budaya terkait } \\
\text { fenomena dan kejadian } \\
\text { tampak mata. }\end{array}$ & $\begin{array}{l}\text { 4. Menggunakan konsep Perbandingan } \\
\text { Senilai untuk menyelesaikan } \\
\text { masalah nyata dengan menggunakan } \\
\text { tabel atau grafik. }\end{array}$ \\
\hline KI 4 & $\begin{array}{l}\text { Mencoba, mengolah, dan } \\
\text { menyaji dalam ranah } \\
\text { konkret (menggunakan, } \\
\text { mengurai, merangkai, } \\
\text { memodifikasi, dan } \\
\text { membuat) dan ranah abstrak } \\
\text { (menulis, membaca, } \\
\text { menghitung, menggambar, } \\
\text { dan mengarang) sesuai } \\
\text { dengan yang dipelajari di } \\
\text { sekolah dan sumber lain } \\
\text { yang sama dalam sudut } \\
\text { pandang atau teori. }\end{array}$ & \\
\hline
\end{tabular}




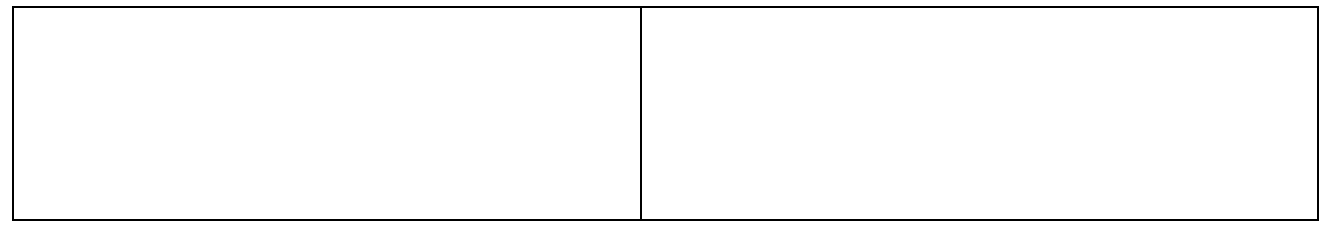

Sumber: Kurikulum Matematika 2013, Kemendikbud 


\section{BAB III}

\section{METODOLOGI PENELITIAN}

\section{A. Metode Penelitian}

Penelitian ini menggunakan metode penelitian dan pengembangan (reseacrh \& development) dengan model desain pembelajaran (design research). Gravemeijer dan Cobb (2006:19) menyatakan bahwa ada 3 tahap dalam pelaksanaan penelitian design research, sebagaimana pada gambar dibawah ini.

Preliminary Design

Teaching Experiment

Retrospective Analysis

\section{Gambar 9. Tahap Pelaksanaan Penelitian Design Research}

\section{B. Prosedur Penelitian}

Prosedur penelitian pengembangan dengan model desain pembelajaran (design research) untuk menghasilkan lintasan pembelajaran dan perangkat pembelajaran yang valid, praktis, dan efektif menggunakan pendekatan PMRI dengan konteks budaya Masohi dilakukan melalui beberapa tahap sebagai berikut:

\section{Tahap desain awal (preliminary design)}

Tahap preliminary design kegiatan yang dilakukan berupa:

a. Melakukan kajian-kajian literatur yang relevan mengenai pendekatan PMRI, konteks budaya setempat, pembelajaran Perbandingan Senilai pada kurikulum di tingkat SMP sebagai dasar untuk merumuskan hipotesis (dugaan pemikiran siswa) selama pembelajaran terhadap 
jawaban siswa disetiap aktivitas pada pembelajaran materi Perbandingan Senilai.

b. Informasi yang diperoleh digunakan untuk mendesain dugaan lintasan belajar (hypothetical learning trajectory) yang terdiri dari tujuan pembelajaran, aktivitas pembelajaran, dugaan pemikiran siswa tentang bagaimana siswa memahami materi Perbandingan Senilai dari tahap informal ke tahap formal.

c. Bersama-sama dengan dosen pembimbing dan guru mata pelajaran mendiskusikan dan merevisi HLT.

d. Membuat perangkat pembelajaran dengan mengacu pada HLT yang telah direvisi. Perangkat pembelajaran yang dibuat antara lain: (1) RPP yang terimplementasi pada langkah-langkah pendekatan PMRI; (2) LKS yang berfungsi untuk mengkonstruksi pengetahuan siswa dalam memahami konsep sehingga setelah menyelesaikan kegiatan yang ada pada LKS, siswa dapat menerapkan konsep tersebut dalam penyelesaian soal-soal; (3) THB yang dibuat dapat digunakan untuk mengukur ketuntasan belajar siswa. Hasil pada tahap awal pembuatan perangkat pembelajaran dan HLT hasil revisi disebut prototipe 1.

e. Validasi desain perangkat pembelajaran yang meliputi:

i. Para ahli dua dosen pendidikan matematika pascasarjana Universitas Negeri Manado dan seorang guru mata pelajaran matematika. Validasi perangkat pembelajaran difokuskan pada 
indikator yang dikemukakan oleh O’Meara dikutip (Sabardin,2004:40), yaitu: isi, format, bahasa, dan ilustrasi serta kesesuaian dengan pendekatan PMRI. Kepada validator diberikan instrumen penelitian berupa lembar validasi dan perangkat pembelajaran yang akan divalidasi. Lembar validasi ini digunakan untuk memperoleh data tentang pendapat, saran dan komentar para ahli mengenai perangkat pembelajaran. Lembar validasi digunakan untuk menilai rencana pelaksanaan pembelajaran, lembar kerja siswa, dan tes hasil belajar. Lembar validasi yang digunakan diadaptasi dari lembar validasi yang telah digunakan oleh Siara (2004:44) dalam penelitian serupa. Modifikasi dilakukan dengan menambah hal-hal yang dianggap perlu dan menghilangkan atau mengganti hal-hal yang dianggap tidak perlu atau kurang sesuai.

ii. Pada tiap-tiap lembar validasi, validator menuliskan penilaiannya. Penilaian terdiri dari 4 kategori, yaitu: tidak baik (nilai 1), kurang baik (nilai 2), baik (nilai 3), sangat baik (nilai 4). Validator juga menuliskan saran dan komentarnya. Data hasil penilaian para ahli untuk masing-masing perangkat pembelajaran dianalisis dengan mempertimbangkan saran dan komentar validator. Hasil analisis perangkat dijadikan pedoman untuk merevisi perangkat pembelajaran matematika dan menghasilkan prototipe 2 . 
f. Sebelum mengimplementasikan HLT dan uji coba perangkat pembelajaran matematika pada tahap teaching experiment, dilakukan terlebih dahulu uji keterbacaan pada perangkat pembelajaran yang telah divalidasi. Hal ini dilakukan untuk melihat apakah perangkat pembelajaran dapat terbaca dengan jelas dan dapat dipahami oleh siswa. Subjek penelitian pada uji keterbacaan adalah 6 orang siswa kelas VII SMP Negeri 1 Masohi. Enam orang siswa tersebut terdiri dari 2 siswa berkemampuan tinggi, 2 siswa berkemampuan sedang, dan 2 siswa berkemampuan rendah. Masukan yang diperoleh dari hasil uji keterbacaan digunakan untuk merevisi prototipe 2 , sehingga dihasilkan prototipe 3 yang akan digunakan pada tahap teaching experiment.

g. Setelah melaksanakan uji keterbacaan guna memperoleh masukan untuk merevisi prototipe 2, peneliti melakukan simulasi pada kelas kecil (pilot experiment) bersama 14 orang dari kelas VII SMP Negeri 1 Masohi. Kelas ini adalah kelas yang tidak digunakan untuk kelas teaching experiment. Peneliti berperan sebagai guru model pada uji coba kelas kecil sedangkan guru mitra mengamati pelaksanaan uji coba agar memperoleh gambaran bagaimana melakukan pembelajaran dengan pendekatan PMRI sesuai dengan rencana pelaksanaan pembelajaran.

\section{Tahap ujicoba pembelajaran (teaching experiment)}


Pada tahap ini dilakukan ujicoba dengan menggunakan prototipe 3 (HLT dan perangkat pembelajaraan matematika yang telah divalidasi). Kegiatan pembelajaran dilakukan tiga kali pertemuan dimana guru Matematika SMP Negeri 1 Masohi yang mengelola pembelajaran, serta pengamat untuk mengobservasi setiap aktivitas belajar siswa. HLT diimplementasikan pada proses pembelajaran dalam memahami materi Perbandingan Senilai, strategi pemikiran siswa yang muncul pada tahap experiment ini akan menjadi dasar untuk mendesain atau memodifikasi HLT sehingga menghasilkan lintasan belajar (learning trajectory) pembelajaran Perbandingan Senilai yang berkembang dari tahap informal ke tahap formal. Untuk perangkat pembelajaran dan instrumen yang telah disusun, diujicobakan pada tahap ini untuk memperoleh masukan langsung dari guru, siswa dan para pengamat (observer). Hasil teaching experiment dijadikan dasar untuk penyempurnaan prototipe 3 menjadi perangkat final.

Pada tahap ini apabila hasil yang diperoleh, dipandang belum memenuhi syarat maka ujicoba dapat dilakukan kembali.

1) Subjek ujicoba

Subjek ujicoba dalam penelitian ini adalah siswa kelas VII SMP Negeri 1 Masohi dengan memilih satu kelas secara acak.

2) Teknik ujicoba 
Tahap ujicoba yang dilakukan dalam penelitian ini menggunakan perangkat pembelajaran yang dikembangkan berdasarkan dugaan lintasan belajar siswa.

\section{Tahap analisis tinjauan (retrospective analysis)}

Tahap ini merupakan tahap analisis data yang diperoleh dari seluruh aktivitas pembelajaran di kelas selama tahap teaching experiment dan penilaian terhadap perangkat pembelajaran matematika.

\section{Hypothetical Learning Trajectory Pembelajaran Perbandingan Senilai}

Aktivitas yang akan dilaksanakan pada pembelajaran, didesain berdasarkan lintasan belajar dan proses berpikir siswa yang telah dihipotesakan. Adapun HLT dalam pembelajaran matematika menggunakan pendekatan PMRI dengan konteks budaya Masohi pada materi Perbandingan Senilai disajikan pada tabel di bawah ini.

Tabel 3. HLT Pembelajaran Perbandingan Senilai

\begin{tabular}{|c|c|c|c|}
\hline $\begin{array}{c}\text { Tujuan } \\
\text { Pembelajaran }\end{array}$ & $\begin{array}{c}\text { Aktivitas } \\
\text { Pembelajaran }\end{array}$ & $\begin{array}{c}\text { Dugaan Pemikiran } \\
\text { siswa }\end{array}$ & Konsep \\
\hline $\begin{array}{l}\text { KD: } \\
\text { - Memahami konsep } \\
\text { perbandingan dan } \\
\text { menggunakan bahasa } \\
\text { perbandingan dalam } \\
\text { mendeskripsikan } \\
\text { hubungan dua } \\
\text { besaran atau lebih } \\
\text { - Menggunakan } \\
\text { konsep perbandingan } \\
\text { senilai untuk } \\
\text { menyelesaikan } \\
\text { masalah nyata } \\
\text { dengan } \\
\text { menggunakan tabel } \\
\text { atau grafik. } \\
\text { Analisis Kebutuhan: }\end{array}$ & $\begin{array}{l}\text { Membagi beras } \\
\text { dengan model } \\
\text { unit satuan. }\end{array}$ & $\begin{array}{l}\text { - Siswa bisa saja } \\
\text { membagi secara } \\
\text { kasar untuk } \\
\text { menemukan hari } \\
\text { keberapa beras } \\
\text { akan habis. } \\
\text { - Siswa akan } \\
\text { berusaha } \\
\text { membagikan } \\
\text { beras dengan adil } \\
\text { sekalipun beras } \\
\text { tersebut tidak } \\
\text { habis dibagi atau } \\
\text { memiliki sisa. } \\
\text { - Siswa bisa saja } \\
\text { salah dalam }\end{array}$ & $\begin{array}{l}\text { Pengukuran, } \\
\text { pembagian, } \\
\text { bilangan } \\
\text { pecahan, } \\
\text { penjumlahan, } \\
\text { geometri, } \\
\text { perbandingan } \\
\text {. }\end{array}$ \\
\hline
\end{tabular}




\begin{tabular}{|c|c|c|c|}
\hline $\begin{array}{l}\text { - Kemampuan siswa } \\
\text { dalam memahami } \\
\text { pengukuran volum } \\
\text { dan berat pada beras, } \\
\text { aljabar, bilangan } \\
\text { pecahan. } \\
\text { Tujuan: } \\
\text { - Siswa mampu } \\
\text { membagi secara adil, } \\
\text { jika tersedia } 25 \mathrm{~kg} \\
\text { beras di dapur dan } \\
\text { dalam sehari } \\
\text { digunakan } \frac{3}{4} \mathrm{~kg} \\
\text { beras. }\end{array}$ & & $\begin{array}{l}\text { membagi beras } \\
\text { setiap hari, hal ini } \\
\text { dikarenakan } \\
\text { terbiasa dengan } \\
\text { situasi "1 kg beras } \\
\text { = } 4 \text { canting } \\
\text { (kaleng) susu". } \\
\text { - Siswa bisa saja } \\
\text { menggambarkan } \\
\text { karung-karung } \\
\text { kecil sebanyak } 25 \\
\text { buah untuk } \\
\text { membagi beras. } \\
\text { - Siswa bisa saja } \\
\text { membuat } \\
\text { pemisalan dengan } \\
\text { menggambarkan } \\
\text { persegi panjang } \\
\text { dan membaginya } \\
\text { menjadi empat } \\
\text { bagian yang sama. } \\
\text { - Siswa bisa saja } \\
\text { menggunakan } \\
\text { kalender. }\end{array}$ & \\
\hline $\begin{array}{l}\text { Analisis Kebutuhan: } \\
\text { - Kemampuan siswa } \\
\text { memahami bilangan } \\
\text { pecahan senilai. } \\
\text { Tujuan: } \\
\text { - Siswa mampu } \\
\text { menuliskan hasil } \\
\text { membagi beras } \\
\text { menurut pecahan } \\
\text { senilai. }\end{array}$ & $\begin{array}{l}\text { Menulis hasil } \\
\text { membagi beras. }\end{array}$ & $\begin{array}{l}\text { - Siswa bisa saja } \\
\text { langsung } \\
\text { memindahkan } 1 \mathrm{~kg} \\
\text { beras ke dalam } 4 \\
\text { gelas yang } \\
\text { bersatuan } \frac{3}{4} \mathrm{~kg} \text { satu } \\
\text { persatu. } \\
\text { - Siswa bisa saja } \\
\text { membuat checklist } \\
\text { tabel mingguan } \\
\text { yaitu setiap } \\
\text { memindahkan } \frac{3}{4} \\
\text { kg beras akan } \\
\text { menconteng satu } \\
\text { hari. } \\
\text { - Siswa bisa saja } \\
\text { menggunakan } \\
\text { pemisalan dengan } \\
1 \text { kg beras }=4 \text { x } \frac{1}{4} \\
\text { kg canting. Pada } \\
\text { bagian ini siswa } \\
\text { menggunakan } \\
\text { strategi } \\
\text { peniumlahan }\end{array}$ & $\begin{array}{l}\text { Bilangan } \\
\text { pecahan } \\
\text { senilai, } \\
\text { aljabar, } \\
\text { penjumlahan } \\
\text { perbandingan } \\
\text { dua besaran } \\
\text { sejenis. }\end{array}$ \\
\hline
\end{tabular}




\begin{tabular}{|c|c|c|c|}
\hline & & $\begin{array}{l}\text { bersusun, } 4 \text { canting } \\
\text { di buat dalam satu } \\
\text { kotak, karena } \\
\text { hanya diperlukan } 3 \\
\text { canting untuk } \\
\text { memasak setiap } \\
\text { hari maka tiap } \\
\text { baris } 3 \text { canting } \\
\text { jumlahkan. } \\
\text { - Siswa mungkin } \\
\text { menuliskan tabel } \\
\text { banyak beras dan } \\
\text { banyak hari, } \\
\text { namun belum bisa } \\
\text { mengaitkan } \\
\text { hubungan antara } \\
\text { konsep bilangan } \\
\text { pecahan senilai } \\
\text { dengan tabel hasil } \\
\text { membagi beras. }\end{array}$ & \\
\hline $\begin{array}{l}\text { Analisis Kebutuhan: } \\
\text { - Kemampuan siswa } \\
\text { dalam memahami } \\
\text { berbagai masalah } \\
\text { dalam kehidupan } \\
\text { sehari-hari yang } \\
\text { dapat diselesaikan } \\
\text { dengan konsep } \\
\text { perbandingan senilai. } \\
\text { Tujuan: } \\
\text { - Siswa mampu } \\
\text { menyimpulkan } \\
\text { materi perbandingan } \\
\text { senilai berdasarkan } \\
\text { kegiatan penemuan } \\
\text { konsep yang } \\
\text { dilakukan. }\end{array}$ & $\begin{array}{l}\text { Melakukan } \\
\text { konstruksi } \\
\text { pengetahuan } \\
\text { matematis } \\
\text { berdasarkan } \\
\text { kegiatan } \\
\text { membagi beras } \\
\text { dan } \\
\text { menyimpulkan } \\
\text { ke tahapan } \\
\text { matematika } \\
\text { formal terkait } \\
\text { materi } \\
\text { perbandingan } \\
\text { senilai. }\end{array}$ & $\begin{array}{l}\text { - Siswa mampu } \\
\text { mengkonstruksi } \\
\text { pengetahuan dan } \\
\text { menyimpulkan } \\
\text { konsep } \\
\text { pembelajaran } \\
\text { perbandingan } \\
\text { senilai berdasarkan } \\
\text { kegiatan penemuan } \\
\text { konsep } \\
\text { yang dilakukan. }\end{array}$ & $\begin{array}{l}\text { Materi } \\
\text { perbandingan } \\
\text { senilai } \\
\text { formal. }\end{array}$ \\
\hline
\end{tabular}

\section{Rancangan Iceberg Pembelajaran Perbandingan Senilai}

Rancangan iceberg pembelajaran menggunakan pendekatan PMRI dari aktivitas pembelajaran yang akan dilakukan untuk memahami Perbandingan Senilai dilihat pada gambar berikut ini. 


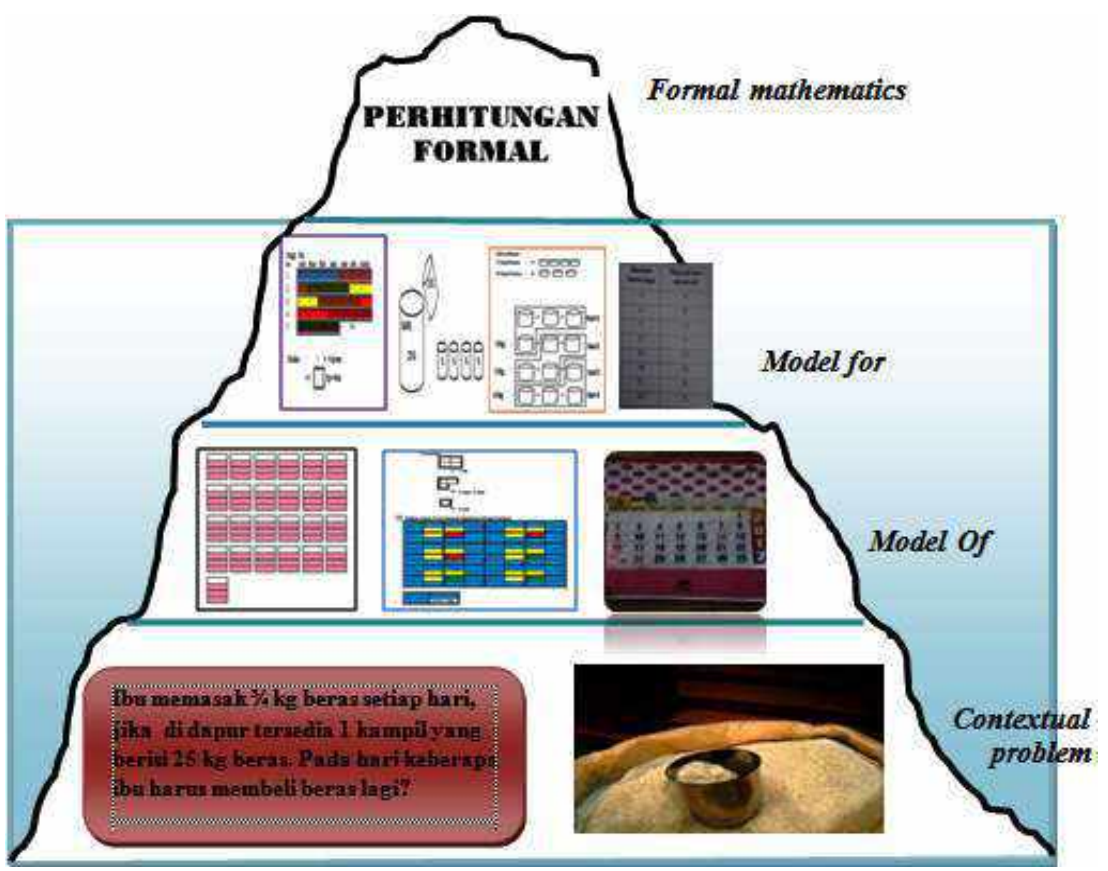

Gambar 10. Rancangan Iceberg Pembelajaran Perbandingan Senilai

Penerapan dari tahap-tahap pengembangan model dalam pembelajaran materi Perbandingan Senilai dijelaskan sebagai berikut:

1) Tahap contextual problem, pada tahap ini konteks beras dijadikan masalah kontekstual.

2) Tahap referential (model of), pada tahap ini ditandai dengan aktivitas membagi beras dan menggambarkan dalam bentuk unitunit satuan geometri.

3) Tahap general (model for), pada tahap ini siswa menuliskan hasil membagi beras dalam bentuk tabel menurut konsep bilangan pecahan senilai.

4) Tahap formal mathematics, pada tahap ini siswa mengkonstruksi pengetahuan dan menyimpulkan ketahapan matematika formal berdasarkan aktivitas yang dilakukan. 


\section{E. Instrumen dan Teknik Pengumpul Data}

Instrumen pengumpulan data pada penelitian ini meliputi: lembar pengamatan aktivitas siswa dalam pembelajaran, lembar pengamatan kemampuan guru dalam mengelola pembelajaran, dan angket respon siswa. Instrumen yang digunakan dalam penelitian ini dapat diuraikan sebagai berikut.

\section{a) Lembar pengamatan aktivitas siswa}

Memperoleh data dari aktivitas siswa selama proses pembelajaran, digunakan instrumen berupa lembar pengamatan aktivitas siswa selama proses pembelajaran. Data tentang aktivitas siswa diperoleh dengan melakukan pengamatan, yang dilakukan oleh seorang pengamat terhadap 4 (empat) orang siswa masingmasing 1 orang siswa dari kelompok atas, 2 orang siswa dari kelompok tengah, dan 1 orang dari kelompok bawah. Pengelompokan ini berdasarkan hasil belajar siswa pada pelajaran matematika sebelumnya.

Lembar pengamatan aktivitas siswa pengamat menuliskan nomor-nomor kategori aktivitas siswa yang dominan muncul dalam kegiatan pembelajaran dalam selang waktu 5 menit. Dalam selang waktu tersebut, setiap 4 menit pengamat melakukan pengamatan terhadap aktivitas siswa, kemudian 1 menit berikutnya pengamat menuliskan nomor-nomor kategori aktivitas siswa.

Aktivitas siswa yang diamati adalah: 
i. Mendengarkan atau memperhatikan penjelasan guru atau teman.

ii. Membaca atau memahami masalah kontekstual di buku siswa atau LKS.

iii. Menyelesaikan masalah atau menemukan cara penyelesaian masalah.

iv. Membandingkan jawaban dalam diskusi kelompok atau diskusi kelas.

v. Bertanya atau menyampaikan pendapat atau ide kepada guru atau teman.

vi. Menarik kesimpulan suatu konsep atau prosedur.

vii. Perilaku yang tidak relevan dengan KBM.

\section{b) Lembar pengamatan kemampuan guru dalam mengelola pembelajaran}

Memperoleh data tentang kemampuan guru dalam mengelola pembelajaran, perlu digunakan instrumen berupa lembar penilaian terhadap pengelolaan pembelajaran dengan menggunakan perangkat pembelajaran yang berorientasi kepada pendekatan PMRI. Dalam pengamatan, pengamat menuliskan kategori-kategori skor yang muncul dengan menggunakan tanda cek $(\sqrt{ })$ pada baris dan kolom yang tersedia. Penilaian terdiri dari 4 kriteria yaitu, tidak baik (nilai 1), kurang baik (nilai 2), baik (nilai 3), sangat baik (4).

Aktivitas guru yang diamati adalah sebagai berikut:

1) Kegiatan pendahuluan, meliputi: 
a. Memeriksa kesiapan siswa.

b. Melakukan kegiatan apersepsi.

c. Menyampaikan tujuan yang akan dicapai dalam proses pembelajaran.

d. Memberikan pemanasan berupa masalah kontekstual yang berhubungan dengan konsep materi pembelajaran.

2) Kegiatan inti, meliputi:

a. Memberikan contoh masalah kontekstual yang berhubungan dengan materi pembelajaran.

b. Memberikan lembar kegiatan siswa dengan masalah kontekstual yang berhubungan dengan materi pembelajaran kepada masing-masing kelompok.

c. Memberikan kesempatan kepada siswa yang mewakili kelompok masing-masing untuk menyampaikan hasil diskusi didepan kelas.

d. Bersama siswa membahas penyelesaian masalah yang berhubungan dengan materi pembelajaran.

e. Memberikan umpan balik.

3) Kegiatan penutup, meliputi:

a. Melengkapi jawaban siswa yang kurang tepat.

b. Memberikan review secara umum, menyampaikan inti pembelajaran kepada siswa, menyampaikan materi pelajaran berikutnya, memotivasi siswa untuk proses pembelajaran 
berikutnya.

c. Memberikan penilaian berupa tes hasil belajar.

\section{c) Angket respon siswa}

Angket digunakan untuk mengumpulkan informasi tentang respon siswa terhadap kegiatan pembelajaran dan perangkat pembelajaran melalui pendekatan PMRI. Angket tersebut diberikan kepada siswa pada akhir kegiatan pembelajaran.

Tanggapan dari siswa yang ingin diketahui adalah:

1) Perasaan siswa selama mengikuti pembelajaran (senang atau tidak).

2) Perasaan siswa terhadap komponen materi pelajaran, lembar kegiatan siswa, tes hasil belajar, suasana pembelajaran dikelas dan cara belajar guru (senang atau tidak).

3) Pendapat siswa terhadap komponen materi pelajaran, lembar kerja siswa, tes hasil belajar, suasana pembelajaran dikelas dan cara belajar guru (baru atau tidak baru).

4) Pendapat siswa tentang bahasa yang digunakan pada komponen lembar kerja siswa dan tes hasil belajar (jelas atau tidak jelas).

5) Pendapat siswa tentang penampilan (tulisan, ilustrasi atau gambar, dan letak gambar) yang terdapat pada lembar kegiatan siswa, dan tes hasil belajar (menarik atau tidak).

\section{F. Teknik Analisis Data}

Teknik analisis data yang digunakan pada tahap uji coba perangkat 
pembelajaran ini adalah analisis deskriptif. Analisis data yang dilakukan adalah analisis data aktivitas siswa, analisis data kemampuan guru dalam mengelola pembelajaran, analisis data respon siswa dan tes hasil belajar.

\section{a) Analisis data aktivitas siswa.}

Data hasil pengamatan aktivitas siswa selama kegiatan pembelajaran dianalisis berdasarkan persentase. Persentase aktivitas siswa yaitu frekuensi suatu aspek pengamatan dibagi dengan jumlah frekuensi semua aspek pengamatan dikali $100 \%$ atau,

Presentase aktivitas siswa $=\frac{\text { Frekuensi aspek pengamatan }}{\text { Jumlah frekuensi aspek pengamatan }} \times 100 \%$

Penentuan kesesuaian aktivitas siswa berdasarkan pada pencapaian waktu ideal yang ditetapkan dalam penyusunan rencana pembelajaran melalui pendekatan PMRI seperti tabel di bawah ini.

Tabel 4. Persentase Waktu Ideal Untuk Aktivitas Siswa

\begin{tabular}{|l|c|c|}
\hline \multirow{2}{*}{ Indikator Pengamatan Aktivitas Siswa } & \multicolumn{2}{|c|}{ Persentase Kesesuaian } \\
\cline { 2 - 3 } & $\begin{array}{l}\text { Waktu } \\
\text { Ideal }\end{array}$ & Toleransi 5\% \\
\hline $\begin{array}{l}\text { Mendengarkan/memperhatikan penjelasan } \\
\text { guru/teman. }\end{array}$ & $13 \%$ & $8 \% \leq \mathrm{P} \leq 18 \%$ \\
\hline $\begin{array}{l}\text { Membaca/memahami masalah kontekstual } \\
\text { di buku siswa atau LKS. }\end{array}$ & $10 \%$ & $5 \% \leq \mathrm{P} \leq 15 \%$ \\
\hline $\begin{array}{l}\text { Menyelesaikan masalah atau menemukan } \\
\text { cara penyelesaian masalah. }\end{array}$ & $27 \%$ & $22 \% \leq \mathrm{P} \leq 32 \%$ \\
\hline $\begin{array}{l}\text { Membandingkan jawaban dalam diskusi } \\
\text { kelompok atau diskusi kelas. }\end{array}$ & $30 \%$ & $25 \% \leq \mathrm{P} \leq 35 \%$ \\
\hline $\begin{array}{l}\text { Bertanya/menyampaikan pendapat/ide } \\
\text { kepada guru atau teman. }\end{array}$ & $10 \%$ & $5 \% \leq \mathrm{P} \leq 15 \%$ \\
\hline
\end{tabular}




\begin{tabular}{|l|c|l|}
\hline $\begin{array}{l}\text { Menarik kesimpulan suatu konsep atau } \\
\text { prosedur. }\end{array}$ & $10 \%$ & $5 \% \leq \mathrm{P} \leq 15 \%$ \\
\hline Perilaku yang tidak relevan dengan KBM. & $0 \%$ & $0 \% \leq \mathrm{P} \leq 5 \%$ \\
\hline
\end{tabular}

(Siara,2004:76)

Aktivitas siswa dikatakan efektif apabila waktu yang digunakan untuk melakukan setiap aspek aktivitas sesuai dengan alokasi waktu yang termuat dalam rencana pelaksanaan pembelajaran dengan toleransi 5\%. Dengan demikian maka, aspekaspek aktivitas siswa yang tidak memenuhi kriteria baik akan merupakan dasar untuk merevisi perangkat pembelajaran.

\section{b) Analisis data kemampuan guru mengelola pembelajaran}

Data tentang kemampuan guru mengelola pembelajaran dianalisa dengan menggunakan statistik deskriptif dengan skor rata-rata. Adapun pendeskripsian skor rata-rata tingkat kemampuan guru (TKG) sebagai berikut:

$$
\begin{aligned}
& 1,00 \leq \mathrm{TKG}<1,50 \text { tidak baik } \\
& 1,50 \leq \mathrm{TKG}<2,50 \text { kurang baik } \\
& 2,50 \leq \mathrm{TKG}<3,50 \text { cukup baik } \\
& 3,50 \leq \mathrm{TKG}<4,50 \text { baik } \\
& 4,50 \leq \mathrm{TKG} \leq 5,00 \text { sangat baik }
\end{aligned}
$$

(Hasratuddin,2002:27).

Kemampuan guru mengelola pembelajaran dikatakan efektif jika skor dari setiap aspek yang dinilai berada pada kategori baik atau sangat baik. Dengan demikian maka hasil analisis data yang tidak memenuhi dari salah satu kategori baik atau sangat baik pada 
penelitian ini akan dijadikan bahan pertimbangan untuk merevisi perangkat pembelajaran yang telah diujicobakan.

\section{c) Analisis data respon siswa}

Data respon siswa yang diperoleh melalui angket dianalisis berdasarkan persentase. Respon siswa dikatakan positif jika $80 \%$ atau lebih siswa merespon dalam kategori senang, baru, berminat, jelas, atau tertarik, untuk setiap aspek yang direspon.

\section{d) Tes hasil belajar}

Tes Hasil Belajar digunakan untuk memperoleh informasi tentang kemampuan siswa terhadap materi pembelajaran. Bentuk tes adalah uraian dan tergolong tes beracuan patokan (PAP). Agar tes yang disusun berkualitas memadai maka diperlukan analisis butir. Analisis butir tes meliputi uji validitas, dan uji reliabilitas.

1) Validitas butir soal

Validitas tes dapat didefenisikan sebagai seberapa jauh perangkat tes itu dapat mengukur kemampuan siswa pada pembelajaran sesuai dengan tujuan yang telah ditetapkan. Rumus yang digunakan adalah rumus korelasi product moment (Arikunto,2001:109) sebagai berikut:

$$
r_{x y}=\frac{N \sum x y-\left(\sum x\right)\left(\sum y\right)}{\sqrt{\left\{N \sum x^{2}-\left(\sum x\right)^{2}\right\}\left\{N \sum y^{2}-\left(\sum y\right)^{2}\right\}}}
$$

keterangan, $r_{x y}=$ koefisien korelasi antara skor butir dengan skor total 


$$
\begin{array}{ll}
x & =\text { skor butir } \\
\mathrm{y} & =\text { skor total } \\
\mathrm{N} & =\text { banyaknya siswa yang mengikuti tes }
\end{array}
$$

Nilai $r_{x y}$ diinterpretasikan sebagai berikut.

$0,80 \leq r_{x y} \leq 1,00 \quad$ : validitas butir tes sangat tinggi

$0,60 \leq r_{x y}<0,80 \quad$ : validitas butir tes tinggi

$0,40 \leq r_{x y}<0,60 \quad$ : validitas butir tes cukup

$0,20 \leq r_{x y}<0,40 \quad$ : validitas butir tes rendah

$0,00 \leq r_{x y}<0,20 \quad$ : validitas butir tes sangat rendah.

Dalam penelitian ini, butir tes dikatakan valid jika mempunyai validitas cukup, tinggi, atau sangat tinggi. Butir-butir tes yang memiliki validitas rendah dan sangat rendah akan diganti atau direvisi.

2) Reliabilitas

Reliabilitas instrumen tes dihitung untuk mengetahui konsistensi hasil tes. Untuk menghitung reliabilitas instrumen tes ini digunakan rumus yang sesuai dengan bentuk tes uraian (essay), yaitu rumus alpha (Nur,1987:93) sebagai berikut.

$$
r_{11}=\left(\frac{n}{n-1}\right)\left[1-\frac{\sum \sigma_{b}^{2}}{\sigma_{t}^{2}}\right]
$$

keterangan,

$\begin{array}{ll}r_{11} & : \text { koefisien reliabilitas instrumen tes } \\ n & : \text { banyaknya item tes } \\ \sum \sigma_{b}^{2} & : \text { jumlah varians skor setiap butir tes } \\ \sigma_{t}^{2} & : \text { varians total }\end{array}$


Interpretasi koefisien reliabilitas instrumen tes ini menggunakan klasifikasi berikut.

$\begin{array}{ll}0,800<\mathrm{r}(\alpha) \leq 1,000 & : \text { reliabilitas tes sangat tinggi } \\ 0,600<\mathrm{r}(\alpha) \leq 8,000 & : \text { reliabilitas tes tinggi } \\ 0,400<\mathrm{r}(\alpha) \leq 0,600 & : \text { reliabilitas tes cukup } \\ 0,200<\mathrm{r}(\alpha) \leq 0,400 & : \text { reliabilitas tes rendah } \\ 0,000<\mathrm{r}(\alpha) \leq 0,200 & : \text { reliabilitas tes sangat rendah. }\end{array}$

Dalam penelitian ini butir tes hasil belajar dikatakan realiabel jika mempunyai reliabilitas cukup, tinggi, atau sangat tinggi.

\section{G. Kriteria Perangkat Pembelajaran}

Perangkat pembelajaran yang valid (Akker,1999:126) adalah perangkat yang setelah divalidasi oleh para ahli dan diujicobakan, memenuhi kriteria:
a. Aktivitas siswa efektif;
b. Kemampuan guru mengelola pembelajaran efektif;
c. Respon siswa positif;
d. Tes hasil belajar valid dan reliabel.

Jika sudah memenuhi kriteria diatas, maka perangkat pembelajaran sudah valid.

Perangkat pembelajaran yang praktis (Akker,1999:126) adalah perangkat pembelajaran yang dapat diterapkan atau di ujicobakan dengan baik.

Perangkat pembelajaran yang efektif (Akker,1999:126) adalah perangkat pembelajaran yang memenuhi kriteria sebagai berikut:

a. Ketuntasan belajar secara klasikal; 
b. Kemampuan guru mengelola pembelajaran efektif;

c. Aktivitas siswa efektif;

d. Respon siswa positif. 


\section{BAB IV}

\section{HASIL DAN PEMBAHASAN}

\section{A. Implementasi Desain Pembelajaran dan Hasil Pengembangan Perangkat}

Tujuan penelitian ini adalah (1) Menghasilkan lintasan belajar siswa dalam memahami materi Perbandingan Senilai menggunakan pendekatan PMRI dengan konteks budaya Masohi; (2) Menghasilkan perangkat pembelajaran matematika yang valid, praktis, dan efektif menggunakan pendekatan PMRI dengan konteks budaya Masohi pada materi Perbandingan Senilai.

Melalui prosedur pengembangan dengan model design reseacrh yang dijelaskan pada BAB III, maka pada bab ini akan dipaparkan hasil pengembangan dari setiap tahapan tersebut yakni preliminary design, teaching experiment dan retrospective analysis. Hasil pengembangan perangkat berupa: Rencana Pelaksanaan Pembelajaran (RPP), Lembar Kerja Siswa (LKS), dan Tes Hasil Belajar (THB).

\section{Hasil tahap preliminary design}

\section{a. HLT pembelajaran perbandingan senilai hasil revisi}

\section{Aktivitas pembelajaran 1: membagi beras dengan model unit satuan}

Tujuan pembelajaran:

1. Mengenalkan siswa melakukan pengukuran menggunakan unit-unit geometri.

2. Menstimulus siswa pada konsep pembagian secara adil (fair share). 
3. Siswa mampu menyatakan masalah sehari-hari kedalam bentuk perbandingan.

Deskripsi aktivitas:

Pada aktivitas ini pertama-tama guru akan menanyakan beberapa pertanyaan mengenai kebiasaan para ibu dalam mengukur beras untuk dimasak, benda apa saja yang digunakan untuk mengukur beras. Kemudian guru memasukan konteks beras kedalam masalah kontekstual yang apabila dihadapi oleh ibu mereka. Jika ibu memasak $\frac{3}{4} \mathrm{~kg}$ beras setiap hari, sementara didapur tersedia 1 kampil yang berisi $25 \mathrm{~kg}$ beras. Pada hari keberapa ibu harus membeli beras lagi?. Pada tahap ini siswa diminta berdiskusi membantu ibu menemukan hari keberapa berasnya akan habis sehingga ibu dapat membeli beras lagi untuk menutupi kekurangan beras. Semua kegiatan pada aktivitas ini dimuat pada LKS1.

Dugaan pemikiran siswa:

1. Siswa bisa saja membagi secara kasar untuk menemukan hari keberapa beras akan habis.

2. Siswa akan berusaha membagikan beras dengan adil sekalipun beras tersebut tidak habis dibagi atau memiliki sisa. Namun pada tahap ini siswa belum mengetahui beras yang tidak habis dibagi merupakan "sisa pembagian".

3. Siswa bisa saja salah dalam membagi beras setiap hari, hal ini dikarenakan terbiasa dengan situasi " $1 \mathrm{~kg}$ beras = 4 canting (kaleng)". 
4. Siswa bisa saja menggambarkan karung kecil sebanyak 25 buah dengan mengasumsikan dalam satu karung terdapat $1 \mathrm{~kg}$ beras $=4$ canting, kemudian mengarsir/mewarnai $\frac{3}{4}$ bagian dan mulai menjumlahkannya.

5. Siswa bisa saja melakukan pemisalan dengan mengambar persegi panjang kemudian membaginya dalam empat bagian yang sama mewakili $1 \mathrm{~kg}$ beras (3 kotak dengan warna yang sama +1 kotak yang berwarna berbeda), karena dibagi menjadi 4 bagian maka satu kotak kecil diasumsikan $\frac{1}{4} \mathrm{~kg}$ beras.

6. Siswa bisa saja menggunakan kalender bulan April-Mei tahun 2017 untuk membagi beras yang akan dimasak. Cara yang digunakan siswa adalah setiap 3 canting mencoret 1 hari di kalender agar tidak lupa hitungan harinya. Setelah 8 hari dihabiskan $6 \mathrm{~kg}$ beras. Sehingga 24 kg akan habis dalam waktu 32 hari pada tanggal 2 mei 2017. Masih tersisa $1 \mathrm{~kg}$ untuk digunakan dalam 1 hari dan masih tersisa 1 canting $\left(\frac{1}{4} \mathrm{~kg}\right)$. Sehingga ibu harus membeli beras lagi pada hari ke- 34 yaitu pada tanggal 4 Mei dengan masih tersisa $\frac{1}{4} \mathrm{~kg}$ beras atau sekitar 1 canting beras.

Untuk mengantisipasi dugaan pemikiran siswa, maka guru dapat memberi petunjuk ataupun pertanyaan-pertanyaan yang bersifat menuntun sebagai berikut:

1) Mengingatkan kembali tentang bilangan pecahan. 
2) Mengingatkan kembali tentang operasi bilangan pecahan.

3) Mengingatkan kembali tentang bentuk waktu.

\section{Aktivitas pembelajaran 2: menulis hasil membagi beras}

Tujuan pembelajaran:

1. Mengaplikasikan konsep bilangan pecahan senilai pada hasil membagi beras.

2. Siswa mampu menyajikan hasil membagi beras dalam bentuk tabel.

3. Siswa mampu menyatakan perbandingan dua besaran ke bentuk yang paling sederhana.

Deskripsi aktivitas:

Pada aktivitas ini siswa akan menuliskan hasil membagi beras, tetapi tidak lagi menggunakan unit satuan pada aktivitas sebelumnya. Siswa akan menuliskan dalam bentuk tabel hasil membagi beras dengan cara/tekhnik yang mereka temukan menurut konsep bilangan pecahan senilai. Guru akan membimbing siswa untuk mencari hubungan antara hasil membagi beras yang ditulis dalam bentuk tabel dengan bilangan pecahan senilai.

Dugaan pemikiran siswa:

1. Siswa bisa saja langsung memindahkan $1 \mathrm{~kg}$ beras ke dalam 4 gelas yang bersatuan $\frac{3}{4} \mathrm{~kg}$ satu per satu. Pada pemindahan canting ke-3, maka akan diketahui bahwa $3 \mathrm{~kg}$ beras dimasak untuk 4 hari. Dengan menggunakan kalkulasi logika, siswa dapat dengan mudah menghitungnya. 
2. Siswa bisa saja membuat checklist tabel mingguan yaitu setiap memindahkan $\frac{3}{4} \mathrm{~kg}$ beras akan menconteng satu hari, setelah 4 hari telah tercatat pada tabel checklist jumlah beras yang dipindahkan sebanyak $3 \mathrm{~kg}$, siswa juga dapat membuat langsung checklist tabel mingguan per 4 hari sampai berasnya habis $25 \mathrm{~kg}$, namun siswa bisa saja belum menuliskannya dalam bentuk tabel.

3. Siswa bisa saja menggunakan pemisalan dengan $1 \mathrm{~kg}$ beras $=4 \times 1 / 4 \mathrm{~kg}$ canting. Pada bagian ini siswa menggunakan strategi penjumlahan bersusun, 4 canting di buat dalam satu kotak, karena hanya diperlukan 3 canting untuk memasak setiap hari maka tiap baris 3 canting jumlahkan. 3 canting pada kotak pertama di tambahkan $=$ hari pertama, 1 canting sisa kotak pertama +2 canting kotak kedua $=$ hari kedua, 2 canting sisa kotak kedua +1 canting kotak ketiga $=$ hari ketiga, 3 canting sisa kotak ketiga $=$ hari keempat. Dengan cara di atas dapat diketahui bahwa dalam 4 hari menghabiskan $3 \mathrm{~kg}$. Kemudian menuliskan hasilnya dalam bentuk tabel.

4. Siswa mungkin akan menuliskan tabel banyak beras dan banyak hari, namun belum bisa dalam mengaitkan hubungan antara konsep bilangan pecahan senilai dengan tabel hasil membagi beras. Jika hal ini terjadi, guru dapat berperan sebagai fasilitator dalam membantu menemukan jawaban persoalan tersebut dengan menyelesaikan LKS bagian 2 . 
Untuk mengantisipasi dugaan pemikiran siswa, maka guru dapat memberi petunjuk atau pertanyaan-pertanyaan yang bersifat menuntun sebagai berikut.

a) Mengingatkan kembali pecahan senilai.

b) Mengingatkan kembali operasi bilangan.

c) Memberi petunjuk agar dapat menuliskan hasil membagi beras dalam bentuk tabel secara terurut.

\section{$\underline{\text { Aktivitas pembelajaran 3: melakukan konstruksi pengetahuan }}$}

\section{matematis berdasarkan kegiatan membagi beras}

Tujuan pembelajaran:

1. Siswa mampu melakukan konstruksi pengetahuan matematis berdasarkan kegiatan membagi beras dan menyimpulkan ke tahapan matematika formal terkait materi Perbandingan Senilai.

2. Siswa mampu menyimpulkan materi Perbandingan Senilai berdasarkan kegiatan penemuan konsep yang dilakukan.

Deskripsi aktivitas:

Pada aktivitas ini, siswa akan melakukan konstruksi pengetahuan matematis berdasarkan kegiatan membagi beras dari tabel perbandingan yang telah di buat pada aktivitas sebelumnya untuk menyimpulkan ke tahapan matematika formal terkait materi Perbandingan Senilai.

Dugaan pemikiran siswa: 
Siswa mampu mengkonstruksi pengetahuan dan menyimpulkan konsep pembelajaran Perbandingan Senilai berdasarkan kegiatan penemuan konsep yang dilakukan.

Untuk mengantisipasi dugaan pemikiran siswa, maka guru dapat memberi petunjuk yaitu meminta siswa untuk teliti menggambarkan grafik berdasarkan tabel yang dibuat.

\section{b. Perangkat pembelajaran matematika menggunakan pendekatan PMRI dengan konteks budaya Masohi}

Berdasarkan kajian literatur yang relevan dan hasil revisi HLT, maka peneliti akan membuat perangkat pembelajaran matematika dengan mengacu pada HLT untuk materi Perbandingan Senilai menggunakan pendekatan PMRI. Semua hasil rancangan pada tahap ini disebut prototipe 1 . Secara garis besar hasil rancangan prototipe 1 perangkat pembelajaran adalah sebagai berikut:

1. Rencana pelaksanaan pembelajaran

Rencana pelaksanaan pembelajaran untuk 3 pertemuan dijabarkan sebagai berikut.

a. Rencana pelaksanaan pembelajaran I

Alokasi waktu 2 x 40 menit dengan materi pengertian dan masalah perbandingan. Indikator pencapaian hasil belajar dijabarkan sebagai berikut.

i. Siswa mampu menuliskan masalah sehari-hari kedalam pernyataan perbandingan. 
ii. Siswa mampu menyelesaikan masalah sehari-hari yang berkaitan dengan konsep perbandingan.

b. Rencana pelaksanaan pembelajaran II

Alokasi waktu 2 x 40 menit dengan materi perbandingan dua besaran atau lebih. Indikator pencapaian hasil belajar dijabarkan sebagai berikut.

i. Siswa mampu menyelesaikan masalah sehari-hari yang berkaitan dengan perbandingan dua besaran atau lebih.

ii. Siswa mampu menyatakan perbandingan dua besaran atau lebih ke bentuk yang paling sederhana.

c. Rencana pelaksanaan pembelajaran III

Alokasi waktu 2 x 40 menit dengan materi model matematika dari masalah nyata. Indikator pencapaian hasil belajar dijabarkan sebagai berikut.

i. Siswa mampu membuat model matematika dari masalah nyata terkait perbandingan senilai.

ii. Siswa mampu menyelesaikan masalah perbandingan senilai dalam bentuk tabel dan grafik.

2. Lembar kerja siswa

Lembar kerja siswa merupakan tempat untuk menuliskan jawaban dari masalah kontekstual yang terdapat pada buku siswa. Pada lembar kegiatan siswa 
juga terdapat informasi-informasi penting yang berhubungan dengan konsep-konsep yang diajarkan. LKS dibuat untuk tiga kali pertemuan.

3. Penyusunan tes hasil belajar

Berdasarkan indikator hasil belajar yang ingin dicapai tersebut di atas, disusunlah alat evaluasi. Evaluasi atau tes yang disusun berbentuk tes uraian yang tergolong tes beracuan patokan (PAP), karena tes ini digunakan untuk mengukur seberapa jauh pencapaian hasil belajar yang telah dirumuskan. Dalam penelitian, tes yang dilakukan berupa tes kognitif. Tes hasil belajar disusun dan dikembangkan berdasarkan kompetensi dasar yang akan dicapai. Berikut ini kisi-kisi tes hasil belajar.

Tabel 5. Kisi-kisi Tes Hasil Belajar $\begin{array}{ll}\text { Nama Sekolah } & \text { : SMP Negeri } 1 \text { Masohi } \\ \text { Mata Pelajaran } & \text { : Matematika } \\ \text { Materi Pokok } & \text { : Perbandingan Senilai }\end{array}$ Kelas/Semester : VII/genap

\begin{tabular}{|c|c|c|c|}
\hline No & $\begin{array}{c}\text { Indikator } \\
\text { Pencapaian Hasil } \\
\text { Belajar }\end{array}$ & $\begin{array}{l}\text { Nomor } \\
\text { Soal }\end{array}$ & $\begin{array}{c}\text { Aspek } \\
\text { Kemampuan }\end{array}$ \\
\hline 1. & $\begin{array}{l}\text { Siswa mampu menuliskan } \\
\text { masalah sehari-hari } \\
\text { kedalam pernyataan } \\
\text { perbandingan }\end{array}$ & $1 \mathrm{a}, 1 \mathrm{~b}$ & $\mathrm{C}_{1}$ \\
\hline 2. & $\begin{array}{l}\text { Siswa mampu } \\
\text { menyelesaikan masalah } \\
\text { sehari-hari yang berkaitan } \\
\text { dengan konsep } \\
\text { perbandingan }\end{array}$ & $2 \mathrm{a}, 2 \mathrm{~b}$ & $\mathrm{C}_{2}$ \\
\hline 3. & $\begin{array}{l}\text { Siswa mampu } \\
\text { menyelesaikan masalah } \\
\text { sehari yang berkaitan }\end{array}$ & $3 b, 3 c, 3 d$ & $\mathrm{C}_{3}$ \\
\hline
\end{tabular}




\begin{tabular}{|c|l|c|c|}
\hline & $\begin{array}{l}\text { dengan perbandingan dua } \\
\text { besaran }\end{array}$ & & \\
\hline 4. & $\begin{array}{l}\text { Siswa mampu } \\
\text { menyatakan perbandingan } \\
\text { dua besaran atau lebih ke } \\
\text { bentuk yang paling } \\
\text { sederhana }\end{array}$ & $3 \mathrm{a}$ & $\mathrm{C}_{1}$ \\
\hline 5. & $\begin{array}{l}\text { Siswa mampu membuat } \\
\text { model matematika dari } \\
\text { masalah kontekstual } \\
\text { terkait perbandingan } \\
\text { senilai }\end{array}$ & 4 & $\mathrm{C}_{3}$ \\
\hline 6. & $\begin{array}{l}\text { Siswa mampu } \\
\text { menyelesaikan masalah } \\
\text { perbandingan senilai } \\
\text { dalam bentuk tabel dan } \\
\text { grafik }\end{array}$ & $5 \mathrm{a}, 5 \mathrm{~b}, 5 \mathrm{c}$ & $\mathrm{C}_{3}$ \\
\hline
\end{tabular}

Keterangan:

$\mathrm{C}_{1}=$ ingatan

$\mathrm{C}_{2}=$ pemahaman

$\mathrm{C}_{3}=$ aplikasi

\section{c. Validasi perangkat pembelajaran}

Prototipe 1 yang dihasilkan kemudian divalidasi oleh ahli. Penilaian yang dilakukan validator meliputi indikator: format, bahasa, dan isi perangkat pembelajaran. Hasil diskusi dengan mengikuti saran-saran serta petunjuk validator menjadi acuan peneliti dalam melakukan revisi. Perangkat pembelajaran yang telah dinyatakan valid oleh validator dinamakan prototipe 2 . Nama-nama validator dapat dilihat pada tabel di bawah ini.

Tabel 6. Daftar Nama-nama Validator

\begin{tabular}{|c|c|c|}
\hline No & Nama-Nama Validator & Pekerjaan \\
\hline 1. & Dr. Victor Sulangi, M.Sc.Ed & $\begin{array}{c}\text { Dosen Pendidikan Matematika } \\
\text { Universitas Negeri Manado }\end{array}$ \\
2. & Dr. Treesje A. S. Rembet, M.Sc & $\begin{array}{c}\text { Dosen Pendidikan Matematika } \\
\text { Universitas Negeri Manado }\end{array}$ \\
\hline
\end{tabular}




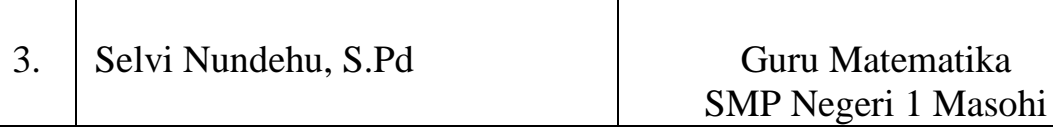

1. Hasil validasi dan revisi Rencana Pelaksanaan Pembelajaran

Penilaian yang dilakukan validator meliputi indikator:

format, bahasa, isi, dan manfaat RPP. Dalam melakukan revisi, peneliti mengacu pada hasil diskusi dengan mengikuti saransaran serta petunjuk validator. Hasil penilaian terhadap RPP disajikan dalam tabel berikut ini.

Tabel 7. Hasil Penilaian Rencana Pelaksanaan Pembelajaran

\begin{tabular}{|c|c|c|c|c|c|}
\hline \multirow[t]{2}{*}{ No } & \multirow[t]{2}{*}{ Aspek yang dinilai } & \multicolumn{4}{|c|}{$\begin{array}{l}\text { Banyak validator } \\
\text { yang memberi nilai }\end{array}$} \\
\hline & & 1 & 2 & 3 & 4 \\
\hline I & $\begin{array}{l}\text { Format RPP: } \\
\text { 1. Format jelas sehingga } \\
\text { memudahkan melakukan } \\
\text { penilaian. } \\
\text { 2. Kemenarikan. }\end{array}$ & & & 3 & 1 \\
\hline II & $\begin{array}{l}\text { Isi RPP: } \\
\text { 1. Kompetensi Inti dan } \\
\text { kompetensi dasar } \\
\text { pembelajaran dirumuskan } \\
\text { dengan jelas. } \\
\text { 2. Tujuan pembelajaran } \\
\text { (indikator yang ingin } \\
\text { dicapai) dirumuskan dengan } \\
\text { jelas. } \\
\text { 3. Menggambarkan kesesuaian } \\
\text { metode pembelajaran dengan } \\
\text { langkah-langkah } \\
\text { pembelajaran yang } \\
\text { dilakukan. } \\
\text { 4. Langkah-langkah } \\
\text { pembelajaran dirumuskan } \\
\text { dengan jelas dan mudah } \\
\text { dipahami. } \\
\end{array}$ & & & 3 & 1 \\
\hline III & $\begin{array}{l}\text { Bahasa danTulisan: } \\
\text { 1. Menggunakan bahasa sesuai } \\
\text { dengan kaidah bahasa } \\
\text { Indonesia yang baku. } \\
\text { 2. Bahasa yang digunakan }\end{array}$ & & & 3 & \\
\hline
\end{tabular}




\begin{tabular}{|c|c|c|c|c|}
\hline & $\begin{array}{l}\text { bersifat komunikatif. } \\
\text { 3. Bahasa mudah dipahami. } \\
\text { 4. Tulisan mengikuti EYD. }\end{array}$ & & 2 & 1 \\
\hline IV & $\begin{array}{l}\text { Manfaat Lembar RPP: } \\
\text { 1. Dapat digunakan sebagai } \\
\text { pedoman untuk pelaksanaan } \\
\text { pembelajaran. }\end{array}$ & & 3 & \\
& $\begin{array}{l}\text { 2. Dapat digunakan untuk } \\
\text { menilai keberhasilan proses } \\
\text { pembelajaran. }\end{array}$ & 3 & \\
\hline & $\begin{array}{l}\text { Penilaian secara umum: dapat digunakan dengan sedikit } \\
\text { revisi }\end{array}$ & & \\
\hline
\end{tabular}

Keterangan:

1 : tidak baik

2 : kurang baik

3 : baik

4 : sangat baik

Dari tabel di atas dilihat bahwa ketiga orang validator memberikan penilaian berkisar antara 3 dan 4 , hal ini berarti komponen-komponen dalam RPP mendapatkan penilaian baik, dan sangat baik. Validator menyarankan agar dalam RPP sebaiknya menguraikan aktivitas pembelajaran antara guru dan siswa, sehingga dapat terlihat dengan jelas interaksi antara guru dan siswa pada proses pembelajaran. Dengan demikian RPP direvisi hanya berdasarkan saran validator.

Tabel 8. Revisi Rencanan Pelaksanaan Pembelajaran

\begin{tabular}{|c|c|c|c|}
\hline $\begin{array}{c}\text { Yang } \\
\text { direvisi }\end{array}$ & Sebelum direvisi & Sesudah direvisi & Alasan direvisi \\
\hline RPP 1 & $\begin{array}{ll}\text { 1. } & \text { Tidak } \\
\text { menguraikan } \\
\text { aktivitas guru } \\
\text { dan aktivitas } \\
\text { siswa } \\
\end{array}$ & $\begin{array}{l}\text { 1. Menguraikan } \\
\text { aktivitas guru } \\
\text { dan aktivitas } \\
\text { siswa }\end{array}$ & $\begin{array}{l}\text { 1. Agar dapat } \\
\text { terlihat dengan } \\
\text { jelas aktivitas } \\
\text { guru dan } \\
\text { aktivitas siswa } \\
\end{array}$ \\
\hline RPP 2 & $\begin{array}{l}\text { 1. Tidak } \\
\text { menguraikan } \\
\text { aktivitas guru } \\
\text { dan aktivitas } \\
\text { siswa } \\
\end{array}$ & $\begin{array}{l}\text { 1. Menguraikan } \\
\text { aktivitas guru } \\
\text { dan aktivitas } \\
\text { siswa }\end{array}$ & $\begin{array}{l}\text { 1. Agar dapat } \\
\text { terlihat dengan } \\
\text { jelas aktivitas } \\
\text { guru dan } \\
\text { aktivitas siswa }\end{array}$ \\
\hline
\end{tabular}




\begin{tabular}{|c|c|c|c|}
\hline RPP 3 & $\begin{array}{l}\text { 1. } \text { Tidak } \\
\text { menguraikan } \\
\text { aktivitas guru } \\
\text { dan aktivitas } \\
\text { siswa }\end{array}$ & $\begin{array}{l}\text { 1. Menguraikan } \\
\text { aktivitas guru } \\
\text { dan aktivitas } \\
\text { siswa }\end{array}$ & $\begin{array}{l}\text { Agar dapat } \\
\text { terlihat dengan } \\
\text { jelas aktivitas } \\
\text { guru dan }\end{array}$ \\
\hline
\end{tabular}

2. Hasil validasi dan revisi Lembar Kerja Siswa

Penilaian yang dilakukan validator meliputi indikator: format, isi, dan bahasa LKS. Dalam melakukan revisi, peneliti mengacu pada hasil diskusi dengan mengikuti saran-saran serta petunjuk validator. Hasil penilaian terhadap LKS disajikan dalam tabel berikut ini.

Tabel 9. Hasil Penilaian Lembar Kerja Siswa

\begin{tabular}{|c|c|c|c|c|c|}
\hline \multirow{2}{*}{ NO } & \multirow{2}{*}{ Aspek yang dinilai } & \multicolumn{4}{|c|}{$\begin{array}{c}\text { Banyak validator yang } \\
\text { memberi nilai }\end{array}$} \\
\hline & & 1 & 2 & 3 & 4 \\
\hline I & $\begin{array}{l}\text { Format LKS: } \\
\text { 1. Kejelasan } \\
\text { pembagian materi } \\
\text { 2. Kemenarikan } \\
\end{array}$ & & & 2 & 1 \\
\hline II & $\begin{array}{c}\text { Isi LKS: } \\
\text { 1. Isi sesuai dengan } \\
\text { kurikulum RPP } \\
\text { 2. Kebenaran } \\
\text { konsep/materi } \\
\text { 3. Kesesuaian urutan } \\
\text { materi } \\
\text { 4. Mengembangkan } \\
\text { karakteristik } \\
\text { Pembelajaran } \\
\text { Matematika } \\
\text { Realistik Indonesia }\end{array}$ & & & 1 & $\begin{array}{l}2 \\
3\end{array}$ \\
\hline III & $\begin{array}{l}\text { Bahasa dan Penulisan: } \\
\text { 1. Soal dirumuskan } \\
\text { dengan bahasa } \\
\text { yang sederhana dan } \\
\text { tidak menimbulkan } \\
\text { penafsiran ganda } \\
\text { 2. Menggunakan } \\
\text { istilah-istilah yang } \\
\text { mudah dipahami } \\
\text { 3. Dirumuskan }\end{array}$ & & & 2 & 3 \\
\hline
\end{tabular}




\begin{tabular}{|l|l|l|l|l|}
\hline & $\begin{array}{l}\text { dengan mengikuti } \\
\text { kaidah bahasa } \\
\text { Indonesia yang } \\
\text { baku }\end{array}$ & & & \\
\hline & $\begin{array}{l}\text { Penilaian secara umum: dapat digunakan dengan sedikit } \\
\text { revisi }\end{array}$ \\
\hline
\end{tabular}

Keterangan:

1 : tidak baik

2 : kurang baik

3 : baik

4 : sangat baik

Dari tabel di atas dilihat bahwa ketiga orang validator memberikan penilaian berkisar antara 3 dan 4 , hal ini berarti komponen-komponen dalam LKS mendapatkan penilaian baik, dan sangat baik. Validator menyarankan pada LKS sebaiknya menyesuaikan masalah dengan lingkungan siswa sehingga masalah yang diberikan dekat dengan siswa dan relevan dalam situasi seharihari. Dengan demikian LKS direvisi hanya berdasarkan saran validator.

Tabel 10. Revisi Lembar Kerja Siswa

\begin{tabular}{|c|c|c|}
\hline $\begin{array}{c}\text { Yang } \\
\text { direvisi }\end{array}$ & Sebelum direvisi & Sesudah direvisi \\
\hline LKS 1 & $\begin{array}{l}\text { Masalah: } \\
\text { Diketahui jumlah mahasiswa } \\
\text { perempuan } 63 \text { orang dan } \\
\text { jumlah mahasiswa laki-laki } \\
45 \text { orang. } \\
\text { Ditanya: } \\
\text { a. Tuliskan perbandingan } \\
\text { anatara banyaknya } \\
\text { mahasiswa perempuan } \\
\text { dan mahasiswa laki-laki. } \\
\text { b. Tuliskan perbandingan } \\
\text { anatara banyaknya } \\
\text { mahasiswa laki-laki dan } \\
\text { mahasiswa perempuan. } \\
\text { c. Samakah perbandingan di } \\
\text { atas? }\end{array}$ & $\begin{array}{l}\text { Masalah: } \\
\text { Perhatikan } \\
\text { teman- } \\
\text { teman } \\
\text { anda } \\
\text { dikelas dan } \\
\text { hitunglah banyak siswa laki- } \\
\text { laki dan perempuan di } \\
\text { kelasmu. } \\
\text { Kemudian jawablah } \\
\text { pertanyaan dibawah ini. }\end{array}$ \\
\hline
\end{tabular}




\begin{tabular}{|c|c|c|}
\hline LKS 2 & $\begin{array}{l}\text { Masalah: } \\
\text { Perbandingan permen Ali } \\
\text { dan permen Bayu adalah } \\
\text { 3: 4. Perbandingan permen } \\
\text { Bayu dengan permen Caren } \\
\text { adalah } 2: 5 \text {. Jumlah permen } \\
\text { mereka bertiga } 102 \text { butir. } \\
\text { a. Temukanlah } \\
\text { perbandingan paling } \\
\text { sederhana dari permen } \\
\text { Ali, Bayu dan Caren. } \\
\text { b. Berapakah permen Ali? } \\
\text { c. Berapakah permen Bayu? } \\
\text { d. Berapakah permen } \\
\quad \text { Caren? }\end{array}$ & $\begin{array}{l}\text { Masalah: } \\
\text { Waktu jam } \\
\text { istirahat } \\
\text { pelajaran } \\
\text { tiba } \\
\text { seluruh siswa pergi membeli } \\
\text { jajanan di kantin SMP Negeri } \\
1 \text { Masohi. Disana ada Prisilia, } \\
\text { Gloria, dan Almendo sedang } \\
\text { membeli permen dengan } \\
\text { jumlah yang berbeda-beda. } \\
\text { Perbandingan permen Prisilia } \\
\text { terhadap permen Gloria } \\
\text { adalah } 3: 4 \text {. Perbandingan } \\
\text { permen Gloria dengan permen } \\
\text { Almendo adalah } 2: 5 \text {. Jumlah } \\
\text { permen mereka bertiga adalah } \\
\text { 102 butir. } \\
\text { a. Tentukan perbandingan } \\
\text { sederhana dari permen } \\
\text { Prisilia, Gloria, dan } \\
\text { Almendo! } \\
\text { b. Berapakah jumlah permen } \\
\text { Prisilia? } \\
\text { c. Berapakah jumlah permen } \\
\text { Gloria? } \\
\text { d. Berapakah jumlah permen }\end{array}$ \\
\hline
\end{tabular}




\begin{tabular}{|c|c|c|}
\hline & & Almendo? \\
\hline LKS 3 & $\begin{array}{l}\text { Masalah: } \\
3 / 4 \mathrm{~kg} \text { beras dimasak setaip } \\
\text { hari, sementara di dapur ada } \\
1 \text { kampil yang berisi } 25 \mathrm{~kg} \\
\text { beras. Pada hari keberapa } \\
\text { harus membeli beras? }\end{array}$ & $\begin{array}{l}\text { Masalah: } \\
\text { Ibu memasak } \\
3 / 4 \mathrm{~kg} \text { beras } \\
\text { per hari, jika } \\
\text { di dapur tersedia } 1 \text { kampil } \\
\text { yang berisi } 25 \mathrm{~kg} \text { beras. Pada } \\
\text { hari keberapa ibu harus } \\
\text { membeli beras lagi? } \\
\text { Bantulah ibu untuk } \\
\text { menemukan hari keberapa } \\
\text { persediaan berasnya akan } \\
\text { habis di dapur }:- \\
\text { Tuliskan apa yang diketahui } \\
\text { dan ditanyakan dalam soal }\end{array}$ \\
\hline & & $\begin{array}{l}\text { Diketahui: } \\
\text { Ditanyakan: }\end{array}$ \\
\hline & & \\
\hline
\end{tabular}

3. Hasil validasi dan revisi Tes Hasil Belajar

Penilaian yang dilakukan validator meliputi indikator: validitas isi, bahas dan kesimpulan THB. Dalam melakukan revisi, peneliti mengacu pada hasil diskusi dengan mengikuti saran-saran serta petunjuk validator. Hasil validitas terhadap THB disajikan dalam tabel berikut ini.

Tabel 11. Hasil Validitas Tes Hasil Belajar

\begin{tabular}{|c|c|c|c|c|c|c|c|c|c|c|c|c|}
\hline \multirow{2}{*}{$\begin{array}{l}\text { Butir } \\
\text { soal }\end{array}$} & \multicolumn{4}{|c|}{ Validitas Isi } & \multicolumn{4}{|c|}{ Bahasa dan Penulisan } & \multicolumn{4}{|c|}{ Kesimpulan } \\
\hline & $\mathbf{V}$ & $\mathrm{CV}$ & KV & TV & SDP & DP & KDP & TDP & TR & RK & RB & PK \\
\hline $1 \mathrm{a}$ & 2 & 1 & & & 3 & & & & & 3 & & \\
\hline $1 \mathrm{~b}$ & 2 & 1 & & & 3 & & & & & 3 & & \\
\hline $2 \mathbf{a}$ & 2 & 1 & & & 3 & & & & & 3 & & \\
\hline $2 \mathrm{~b}$ & 3 & & & & 3 & & & & & 3 & & \\
\hline $3 \mathbf{a}$ & 3 & & & & 2 & 1 & & & 2 & 1 & & \\
\hline $\mathbf{3 b}$ & 3 & & & & 2 & 1 & & & 2 & 1 & & \\
\hline $3 c$ & 3 & & & & 2 & 1 & & & 2 & 1 & & \\
\hline 3d & 3 & & & & 2 & 1 & & & 2 & 1 & & \\
\hline 4 & 3 & & & & & 3 & & & & 3 & & \\
\hline
\end{tabular}




\begin{tabular}{|c|c|l|l|l|l|l|l|l|l|l|l|l|}
\hline $\mathbf{5 a}$ & 3 & & & & 1 & 2 & & & & 3 & & \\
\hline $\mathbf{5 b}$ & 3 & & & & 1 & 2 & & & & 3 & & \\
\hline $\mathbf{5 c}$ & 3 & & & & 1 & 2 & & & & 3 & & \\
\hline
\end{tabular}

Keterangan:

$\mathrm{V} \cdot$ valid

SDP : sangat dapat dipahami

TR : tanpa revisi

CV : cukup valid

DP : dapat dipahami

RK : revisi kecil

$\mathrm{KV}$ : kurang valid

KDP : kurang dapat dipahami

$\mathrm{RB}$ : revisi besar

TV : tidak valid

TDP : tidak dapat dipahami

PK : perlu konsultasi

Dari tabel di atas dilihat bahwa ketiga orang validator memberikan penilaian terhadap komponen-komponen dalam THB dengan penilaian valid dan cukup valid untuk validitas isi, sangat dapat dipahami dan dapat dipahami untuk bahasa dan penulisan, serta kesimpulan dari THB ini adalah dapat digunakan tanpa revisi dan dapat digunakan dengan revisi kecil. Validator menyarankan agar perintah soal diperjelas dan juga menyempurnakan kalimat pada THB. Tujuannya agar maksud soal tersebut dapat lebih dipahami siswa.

Tabel 12. Revisi Tes Hasil Belajar

\begin{tabular}{|c|l|l|}
\hline $\begin{array}{c}\text { Yang } \\
\text { direvisi }\end{array}$ & \multicolumn{1}{|c|}{ Sebelum direvisi } & \multicolumn{1}{c|}{ Sesudah direvisi } \\
\hline No 1 & $\begin{array}{l}\text { Jumlah kancing merah 18 } \\
\text { buah dan kancing hijau 27 } \\
\text { buah. Tentukan } \\
\text { perbandingan dari kedua } \\
\text { kancing di atas. }\end{array}$ & $\begin{array}{l}\text { Nurhayati } \\
\text { mempunyai 18 } \\
\text { buah kancing } \\
\text { warna merah } \\
\text { dan 27 buah kancing wana hijau. } \\
\text { a. Tentukan perbandingan dari } \\
\text { kedua kancing di atas. } \\
\text { Tuliskan bentuk } \\
\text { perbandingan sederhana dari } \\
\text { kedua kancing di atas. }\end{array}$ \\
No 2 & $\begin{array}{l}\text { Ayah 45 } \\
\text { tahun dan } \\
\text { usia ibu } \\
40 \text { tahun, } \\
\text { sedangkan usia Aryo 15 }\end{array}$ & $\begin{array}{l}\text { Usia ayah 45 } \\
\text { tahun dan usia } \\
\text { ibu 40 tahun, } \\
\text { sedangkan } \\
\text { usia Aryo 15 } \\
\text { tahun serta usia Eka 10 tahun. } \\
\text { Tentukan bentuk perbandingan }\end{array}$ \\
\hline
\end{tabular}




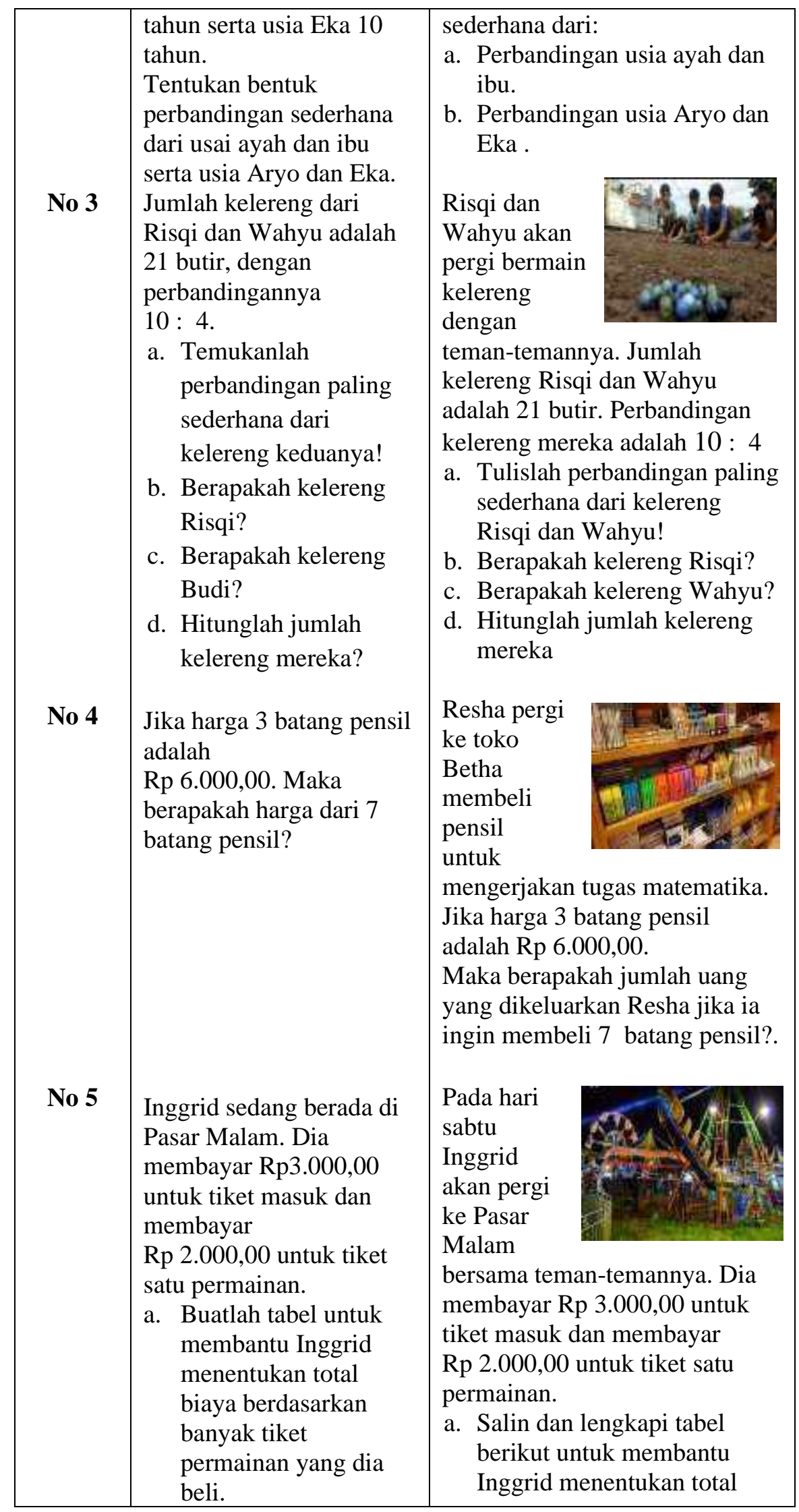




\begin{tabular}{|c|c|c|c|c|c|c|}
\hline \multirow{4}{*}{$\begin{array}{l}\text { b. Buatlah titik-titik } \\
\text { untuk pasangan terurut } \\
\text { yang menyatakan } \\
\text { hubungan banyak tiket } \\
\text { dan total biaya yang } \\
\text { dikeluarkan Inggrid } \\
\text { dan buat garis yang } \\
\text { menghubungkan titik- } \\
\text { titik tersebut. } \\
\text { c. Apakah perbandingan } \\
\text { banyak tiket yang } \\
\text { dibeli terhadap total } \\
\text { biaya yang } \\
\text { dikeluarkan Inggrid } \\
\text { sama untuk setiap } \\
\text { kolom? Apakah situasi } \\
\text { ini proporsional? } \\
\text { Jelaskan! }\end{array}$} & \multicolumn{6}{|c|}{$\begin{array}{l}\text { biaya berdasarkan banyak } \\
\text { tiket permainan yang dia } \\
\text { beli. }\end{array}$} \\
\hline & $\begin{array}{l}\text { Banyak } \\
\text { tiket }\end{array}$ & 2 & 4 & 6 & 8 & 10 \\
\hline & $\begin{array}{l}\text { Biaya } \\
\text { (ribuan } \\
\text { rupiah) }\end{array}$ & $\ldots$ & $\ldots$ & $\cdots$ & $\ldots$ & $\ldots$ \\
\hline & \multicolumn{6}{|c|}{$\begin{array}{l}\text { b. Buatlah titik-titik untuk } \\
\text { pasangan terurut yang } \\
\text { menyatakan hubungan } \\
\text { banyak tiket dan total biaya } \\
\text { yang dikeluarkan Inggrid dan } \\
\text { buat garis yang } \\
\text { menghubungkan titik-titik } \\
\text { tersebut. } \\
\text { c. Apakah perbandingan } \\
\text { banyak tiket yang dibeli } \\
\text { terhadap total biaya yang } \\
\text { dikeluarkan Inggrid sama } \\
\text { untuk setiap kolom? Apakah } \\
\text { masalah ini merupakan } \\
\text { perbandingan senilai? } \\
\text { Jelaskan! }\end{array}$} \\
\hline
\end{tabular}

Hasil revisi perangkat pembelajaran yang telah dinyatakan valid ini akan menghasilkan prototipe 2 dan akan digunakan pada kelas teaching experiment.

\section{d. Uji keterbacaan}

Sebelum dilakukan ujicoba pada tahap teaching experiment dilakukan uji keterbacaan terhadap perangkat pembelajaran yang telah divalidasi. Uji keterbacaan ini terdiri dari enam orang siswa, 2 orang siswa berkemampuan tinggi, 2 orang siswa berkemampuan sedang, dan 2 orang siswa berkemampuan rendah. Hasil analisis uji 
keterbacaan digunakan untuk merevisi prototipe 2. Revisi tersebut dapat dilihat pada tabel berikut.

Tabel 13. Revisi Berdasarkan Uji Keterbacaan

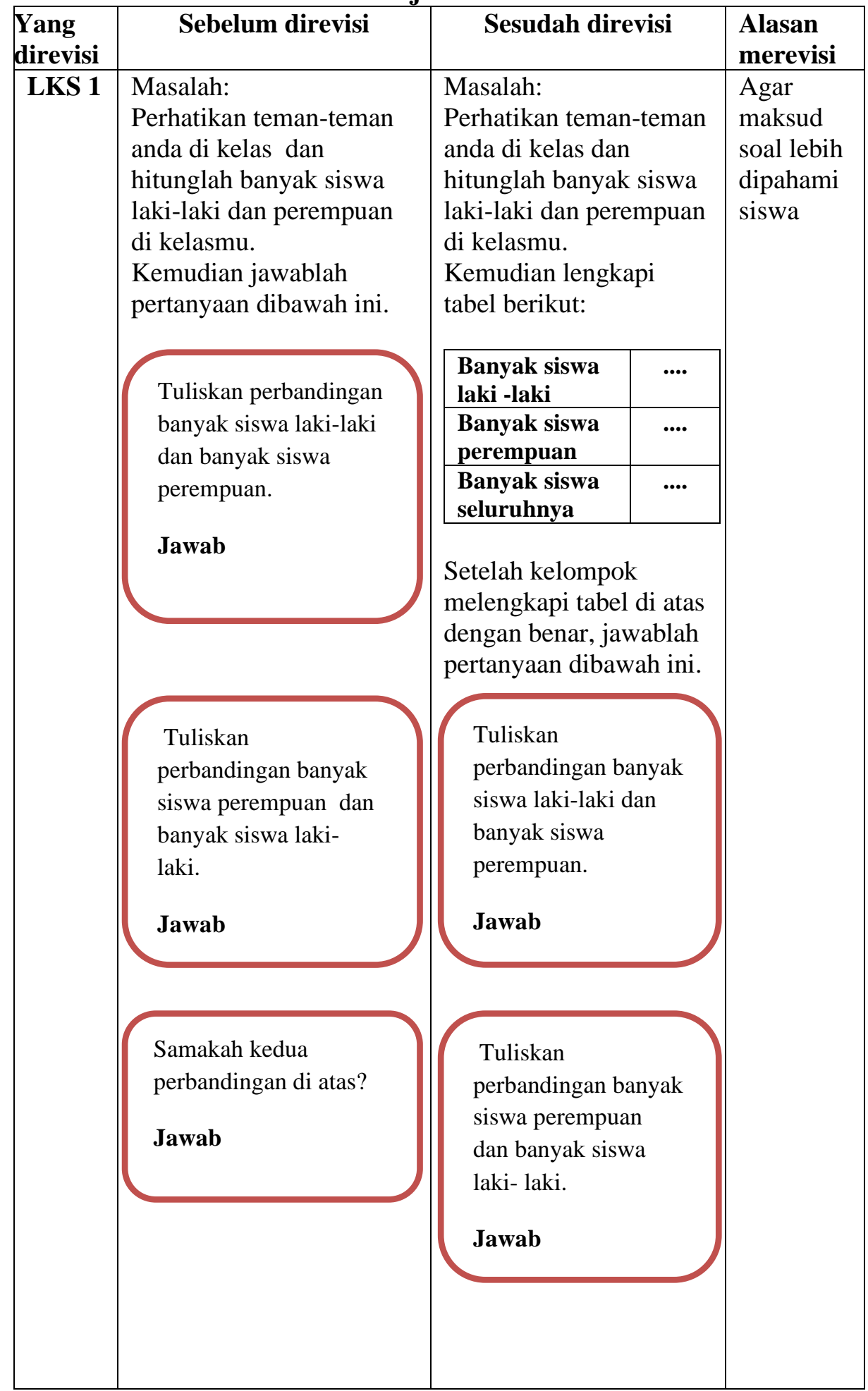




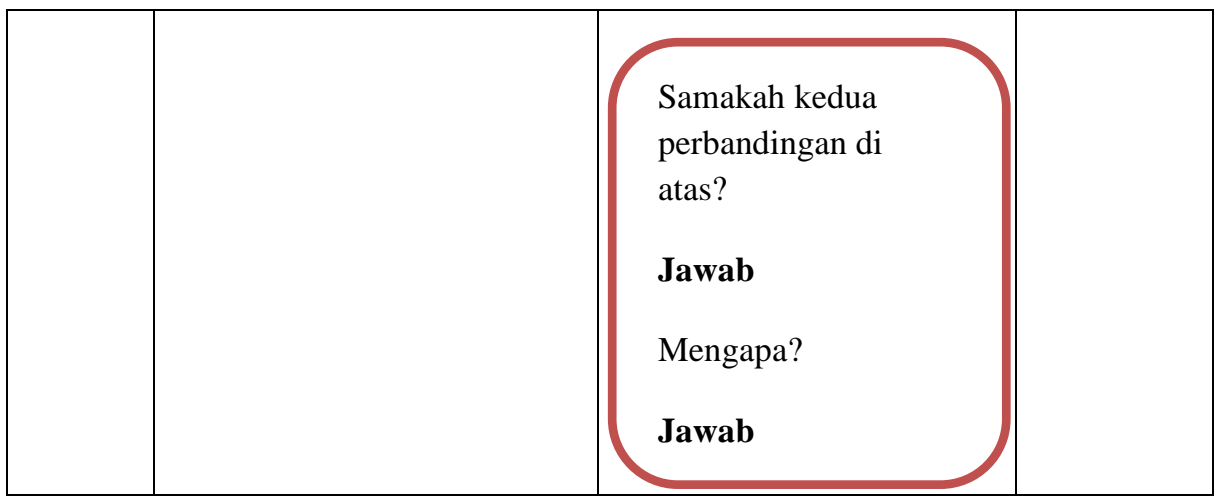

RPP tidak mengalami perubahan. Hasil revisi prototipe 2 yang telah dinyatakan valid ini dinamakan prototipe 3 yang akan digunakan untuk ujicoba pada tahap teaching experiment.

\section{e. Simulasi}

Peneliti melakukan simulasi rencana pelaksanaan pembelajaran pada kelompok kecil (pilot experiment). Simulasi diikuti oleh 14 orang siswa kelas VII SMP Negeri 1 Masohi dan guru mitra. Kelas ini tidak digunakan untuk kelas teaching experiment. Dalam simulasi ini, peneliti bertindak sebagai guru model dengan tujuan agar guru mitra memperoleh gambaran bagaimana melaksanakan pembelajaran sesuai dengan perangkat pembelajaran yang dikembangkan oleh peneliti.

\section{Tabel 14. Jadwal Pelaksanaan Simulasi}

\begin{tabular}{|c|c|l|}
\hline $\begin{array}{c}\text { Pertemuan } \\
\text { ke- }\end{array}$ & Hari/tanggal & \multicolumn{1}{|c|}{ Sub materi } \\
\hline I & Kamis, 06 April 2017 & $\begin{array}{l}\text { Pengertian dan Masalah } \\
\text { Perbandingan } \\
\text { Perbandingan Dua } \\
\text { Besaran atau Lebih } \\
\text { Model Matematika dari } \\
\text { Masalah Nyata }\end{array}$ \\
II & Kamis, 13 April 2017 \\
III & Jumat, 15 April 2017 & \\
\hline
\end{tabular}




\section{Hasil tahap teaching experiment}

Teaching experiment bertujuan untuk mengimplementasikan HLT dan penyempurnaan perangkat pembelajaran. Perangkat pembelajaran yang diujicoba adalah RPP, LKS dan instrumen penelitian yaitu Tes Hasil Belajar. Ujicoba instrumen tes hasil belajar bertujuan untuk mengetahui apakah instrumen yang dikembangkan dapat mengukur hasil belajar siswa.

Kegiatan teaching experiment dilakukan selama 3 kali pertemuan dan ikuti oleh siswa kelas VII. ${ }_{3}$ SMP Negeri 1 Masohi pada minggu ketiga dan keempat bulan April 2017 yang berjumlah 27 orang. Siswa dibagi menjadi 7 kelompok dengan dikondisikan duduk tiap kelompok terdiri dari 4 siswa, masing-masing 1 orang dari kelompok atas, 2 orang dari kelompok tengah dan 1 orang dari kelompok bawah. Pada tahap ini dilibatkan 2 orang pengamat atau observer dengan tugas yang berbeda. Guru SMP Negeri 1 Masohi mengamati aktivitas siswa dan seorang guru lain mengamati kemampuan guru mengelola pembelajaran. Dalam hal ini guru matematika SMP Negeri 1 Masohi yang mengelolah pembelajaran. Pembelajaran diawali dengan guru memberikan apersepsi mengenai bilangan pecahan, menanyakan kebiasaan para siswa membeli jajanan dikantin sekolah dan menyampaikan tujuan pembelajaran yang akan dicapai.

Kegiatan pembelajaran sebelum masuk dalam tahap pemberian masalah kontekstual (contextual problem) sesuai dengan prinsip-prinsip 
pendekatan PMRI, guru terlebih dahulu melakukan tanya jawab dengan siswa mengenai konteks beras yang sangat dekat dengan kehidupan sehari-hari. Guru menanyakan "siapakah diantara kalian yang pernah disuruh ibu untuk membeli beras atau mengukur beras untuk memasak?. Benda apakah yang digunakan penjual atau kalian sendiri pada waktu mengukur beras?." Dari pertanyaan yang diberikan ada beragam jawaban yang diberikan siswa, salah satunya jawaban dari Inggrid "saya pernah melihat ibu saya mengukur beras menggunakan cupa (canting)”. Hal ini sebagaimana ditunjukan pada gambar di bawah ini.

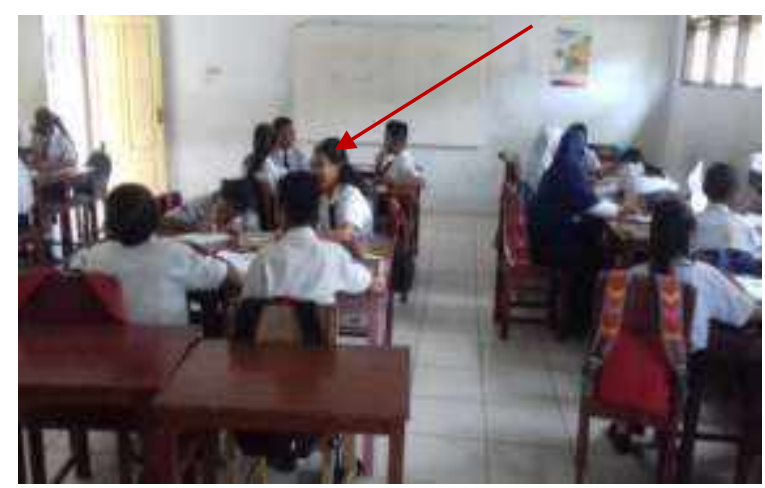

\section{Gambar 11. Antusias Siswa Menjawab Berbagai Pertanyaan}

Tahap pemberian masalah kontekstual

Dari jawaban siswa di atas, kemudian guru memunculkan masalah kontekstual yang jika dialami oleh ibu mereka di rumah. Masalah kontekstual yang diberikan adalah jika ibu memasak $\frac{3}{4} \mathrm{~kg}$ beras setiap hari dan di dapur tersedia 1 kampil yang berisi $25 \mathrm{~kg}$ beras. Pada hari keberapa ibu harus membeli beras lagi?. Pada tahap pemberian masalah kontekstual ini terlihat tiap kelompok bekerja sama untuk menyelesaikan 
permasalahan di atas pada Lembar Kerja Siswa (LKS) 1 yang telah dibagikan.

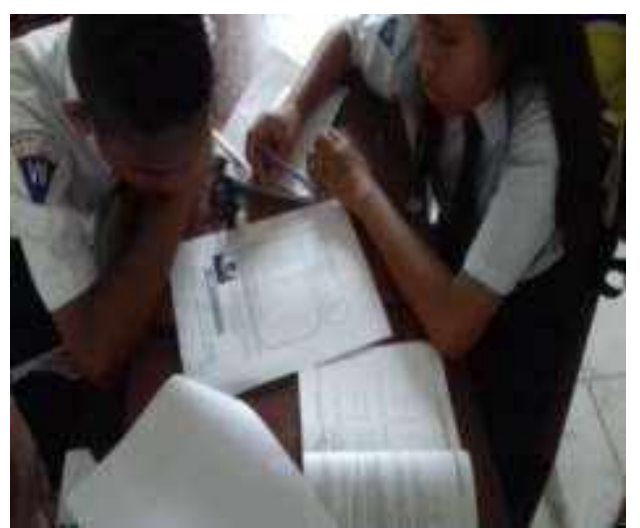

(a)

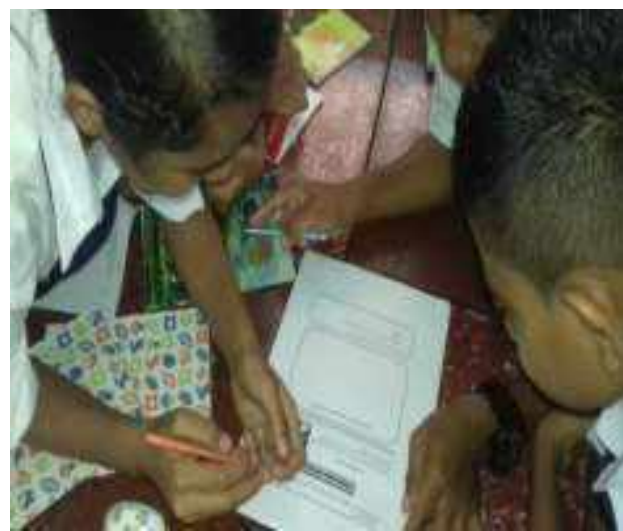

(c)

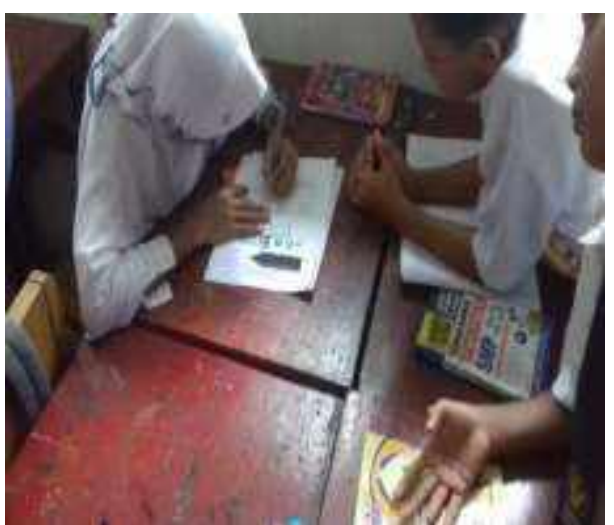

(b)

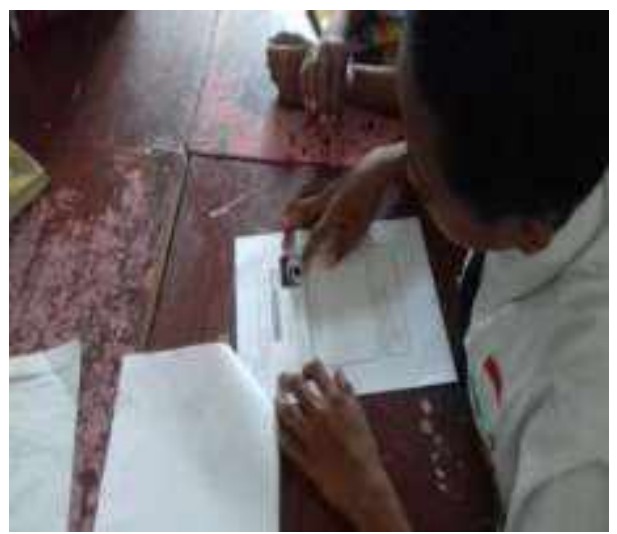

(d)

Gambar 12. Kelompok-klompok Bekerjasama Menyelesaikan Masalah Kontekstual LKS 1 (kelompok 2 (a), kelompok 3 (b), kelompok 6 (c), kelompok 7 (d))

Tahap menjelaskan masalah kontekstual

Guru memberikan kesempatan kepada siswa yang belum memahami permasalahan yang diberikan untuk bertanya tentang masalah kontekstual yang diberikan pada LKS 1. Pada tahap ini ada siswa yang bertanya "jika $1 \mathrm{~kg}$ beras $=4$ cupa (canting), maka $\frac{3}{4} \mathrm{~kg}$ beras itu berapa cupa?". Melalui pertanyaan ini kemudian siswa diberikan sebuah wadah 
yang diasumsikan berisi $25 \mathrm{~kg}$ beras, 1 buah canting besar berukuran 1 kg dan 4 buah canting kecil. Kemudian menyuruhnya untuk membagi 1 $\mathrm{kg}$ beras kedalam empat buah canting kecil. Jawaban dari siswa setelah melakukan kegiatan ini adalah $\frac{3}{4} \mathrm{~kg}$ beras di masak setiap hari maka dibutuhkan 3 canting kecil yang berukuran dan sisanya 1 canting atau $\frac{1}{4}$ kg. Melalui penjelasan yang diberikan, diharapkan siswa dapat mengidentifikasi permasalahan dan mencari solusi yang cocok untuk menyelesaikan permasalahan tersebut. Hal ini dilakukan berdasarkan karateristik pendekatan PMRI yang ke- 4 yaitu adanya interaktivitas pada proses pembelajaran, baik antar siswa ataupun siswa dengan guru.

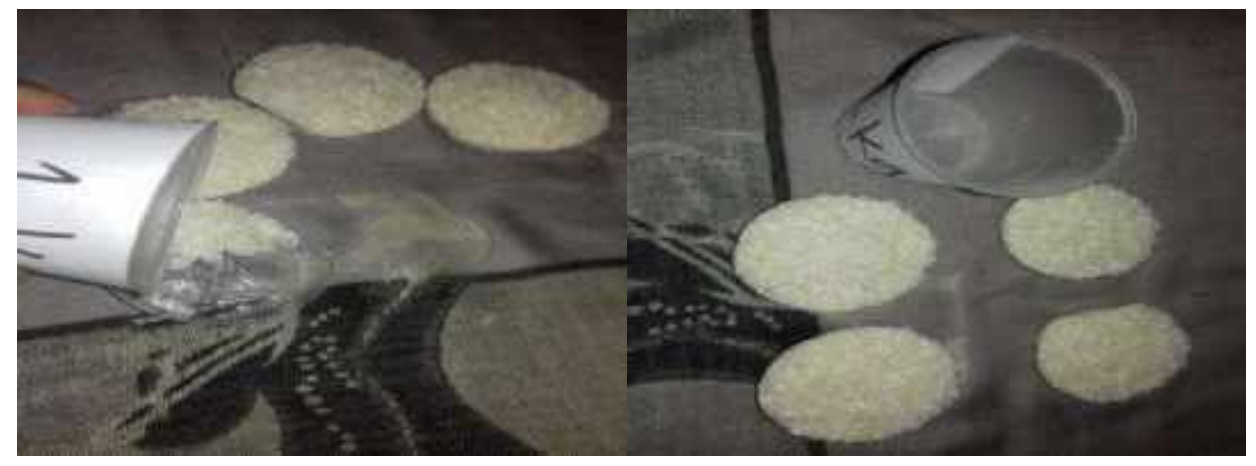

\section{Gambar 13. Aktivitas Siswa Membagi Beras}

Tahap menyelesaikan masalah kontekstual (Aktivitas pembelajaran 1)

Pada aktivitas ini, siswa diberi kebebasan untuk mencari cara/tehknik membagi beras dalam membantu ibu menemukan hari keberapa berasnya akan habis. Awal diskusi berjalan ada beberapa kelompok yang bingung karena mereka terbiasa dengan situasi " $1 \mathrm{~kg}$ beras $=4$ cupa (canting)", hal ini terjadi karena tidak memperhatikan dengan baik pada waktu guru menjelaskan ditahap sebelumnya. Melihat 
hal tersebut, guru membimbing kelompok yang terlihat bingung dalam menyelesaikan permasalahan kontekstual pada LKS 1 dengan memberikan pertanyaan-pertanyaan yang bersifat menuntun mereka dalam memahami pembagian dan bilangan pecahan. Dari masalah kontekstual yang diberikan muncul empat macam strategi siswa dalam menyelesaikan permasalahan yaitu dengan menggunakan unit satuan, hal ini menunjukan kemampuan siswa dalam menyelesaikan permasalahan yang dilakukan dengan menggunakan aktivitas situasional.

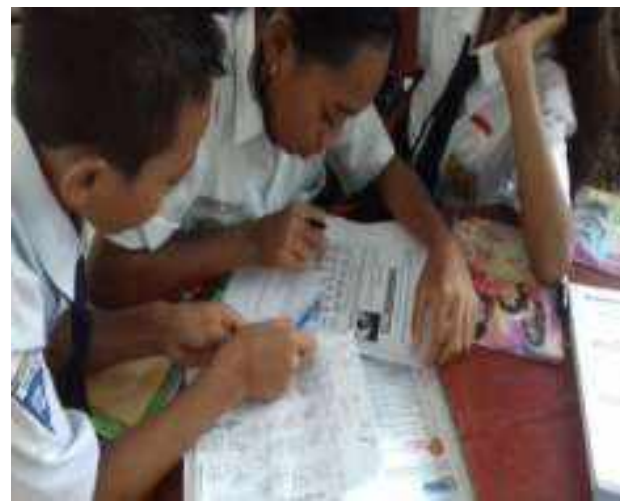

(a)

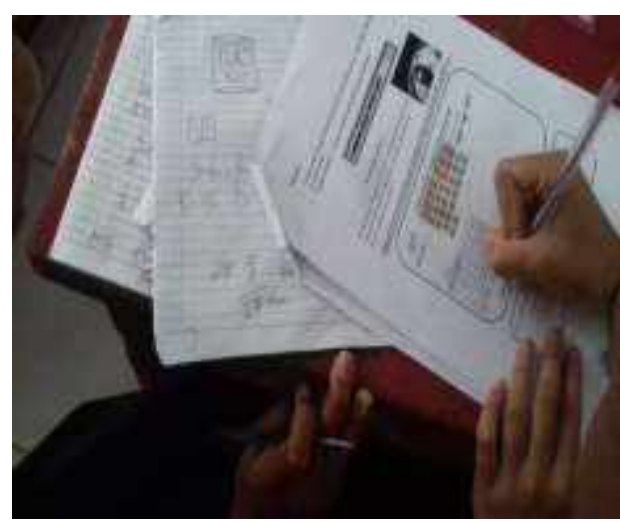

(c)

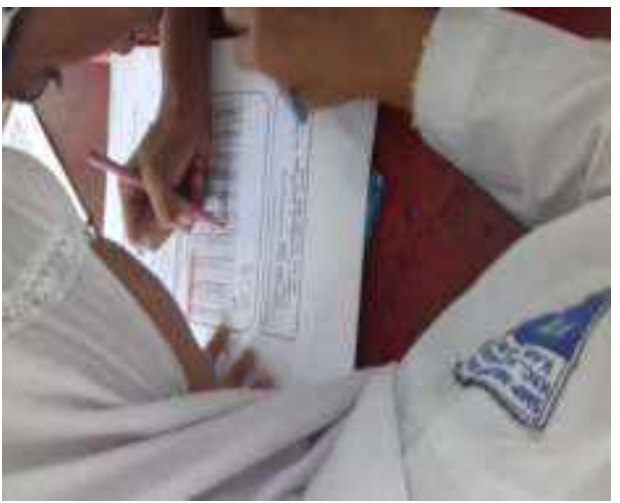

(b)

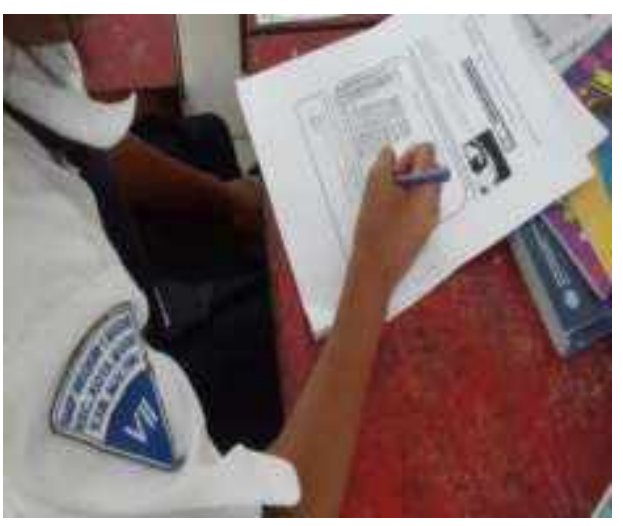

(d)

Gambar 14. Unit-unit Geometri yang Digunakan Siswa Menyelesaikan LKS 1 (kelompok 1 (a), kelompok 4 (b), kelompok 5 (c), kelompok 7 (d)) 
Dari hasil pekerjaan kelompok siswa di atas dapat dilihat bahwa ada berbagai macam unit satuan yang mereka gunakan dalam membagi beras guna untuk mengetahui hari keberapa beras akan habis sebagai berikut:

- Kelompok 1 menyelesaikan dengan cara membuat pemisalan dengan menggambarkan segi empat yang dibagi menjadi 4 kotak kecil didalamnya (diasumsikan tiap kotak berisi $\frac{1}{4} \mathrm{~kg}$ beras) yang sama besar dimana 3 kotak kecil diarsir dan satu kotak tidak diarsir (sisa).

- Kelompok 4 menyelesaikan dengan cara membagi $25 \mathrm{~kg}$ beras dengan menggambar kotak-kotak kecil diasumsikan tiap kotak berisi $\frac{1}{4} \mathrm{~kg}$ beras.

- Kelompok 5 menyelesaikan dengan cara menggunakan kalender untuk membagi $25 \mathrm{~kg}$ beras dengan per harinya $\frac{3}{4} \mathrm{~kg}$.

- Kelompok 7 menyelesaikan dengan cara menggambarkan canting-canting beras yang diasumsikan tiap canting berisi $\frac{3}{4} \mathrm{~kg}$ beras.

Tahap pengembangan masalah kontekstual (Aktivitas pembelajaran 2)

Pada aktivitas ini, siswa tidak lagi menggunakan unit satuan geometri seperti pada aktivitas sebelumnya. Tetapi siswa dibimbing untuk menuliskan hasil membagi beras dalam bentuk pecahan senilai berdasarkan strategi yang mereka temukan pada aktivitas membagi beras. 
- Kelompok 2 langsung menyelesaikan masalah kontekstual dengan menggunakan persamaan matematika formal.

- Kelompok 3 menggunakan cara matematika informal sekaligus matematika formal. Cara yang mereka gunakan adalah menggambarkan canting-canting beras yang diwarnai kemudian menggunakan matematika formal untuk menemukan hari keberapa beras akan habis. Disini strategi yang siswa gunakan benar hanya saja keliru menemukan hari keberapa persediaan beras akan habis. Hal ini disebabkan karena jawaban akhir mereka dibagi 7 (mungkin dalam pemikiran siswa berbicara tentang hari berarti mengarah dalam situasi 1 minggu $=7$ hari).

- Hasil pekerjaan kelompok 6 tidak tepat dan diluar konjektur pemikiran, penyebabnya adalah kelompok membagi beras dengan menggunakan perhitungan waktu (jam). Hal ini mungkin disebabkan persepsi siswa yang keliru dalam memahami masalah.

Untuk lebih jelasnya dapat dilihat pada gambar di bawah ini.

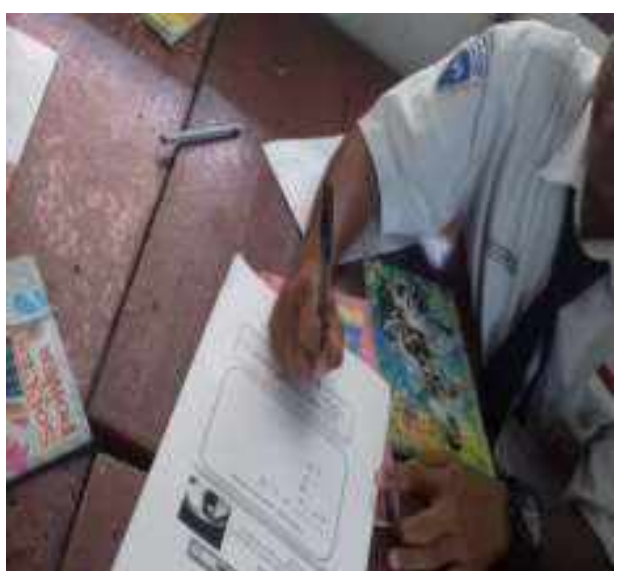

(a)

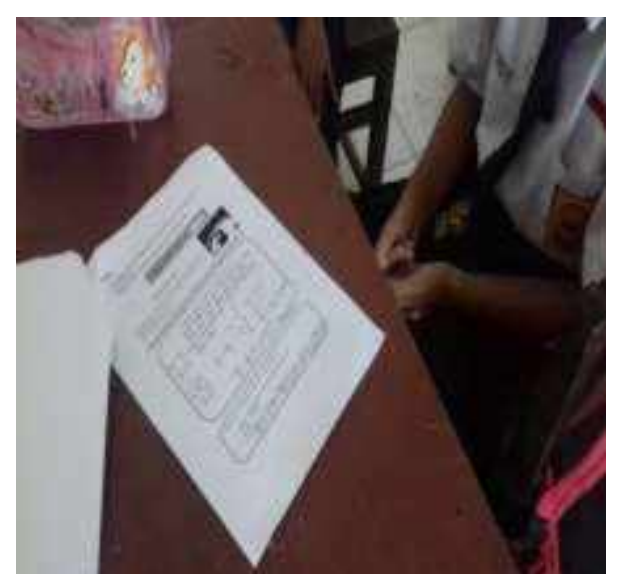

(b) 


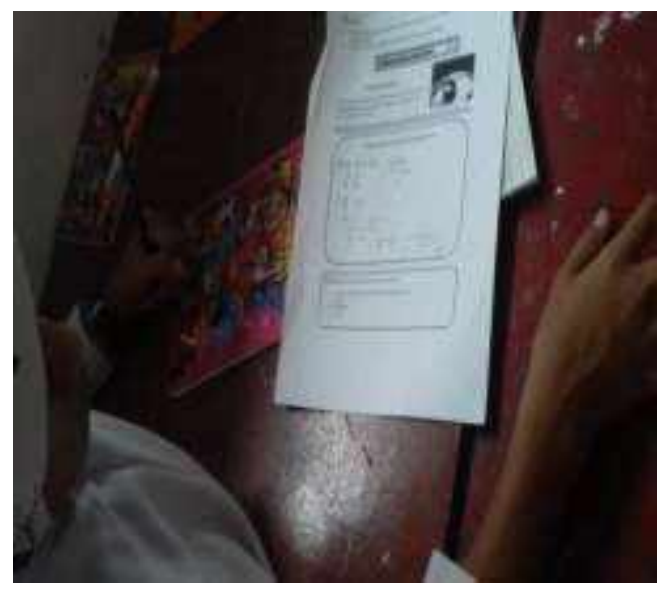

(c)

\section{Gambar 15. Kelompok-kelompok Menyelesaikan Masalah LKS 1 dalam} Bentuk Semi Formal (kelompok 2 (a), kelompok 3 (b), kelompok 6 (c))

Tahap membandingkan dan mendiskusikan jawaban

Siswa diberi kesempatan mempresentasikan hasil diskusi untuk mengeksplorasi lebih lanjut jawaban yang dituliskan pada LKS 1 serta meluruskan pemahaman mereka agar sesuai dengan tujuan pembelajaran. Guru mempersilahkan siswa lain untuk menanggapi hasil pekerjaan dari kelompok yang melakukan presentasi. Berbagai jawaban siswa strategi yang berbeda dapat dibahas, sehingga pada akhirnya siswa dapat memilih strategi yang lebih efektif dalam menyelesaikan masalah kontekstual tersebut. Pada tahap ini terjadi pertukaran informasi, ide dan pendapat dari teman sebaya.

Berdasarkan cara siswa menyelesaikan masalah kontekstual yang diberikan, dapat dilihat ada kelompok yang mencoba menyelesaikan dengan menggunakan unit satuan geometri (model of) yaitu pada kelompok 1 dengan menggambarkan segi empat yang kemudian dibagi menjadi empat kotak kecil, kelompok 4 menggambarkan kotak-kotak 
kecil yang berisi $\frac{3}{4} \mathrm{~kg}$ beras, kelompok 5 menggambarkan kalender dengan membagi $\frac{3}{4} \mathrm{~kg}$ beras setiap hari, kelompok 7 menggambarkan canting-canting beras dengan tiap canting berisi $\frac{1}{4} \mathrm{~kg}$ beras.

Sedangkan cara yang digunakan kelompok 2, kelompok 3, kelompok 6, dan menggunakan model semi formal (model for) untuk menyelesaikan masalah kontekstual. Kelompok 2 langsung menyelesaikan masalah kontektual dengan menggunakan persamaan matematika, kelompok 3 kurang tepat dalam menyelesaikan masalah kontekstual yang diberikan karena disebabkan jawaban akhir mereka dibagi tujuh (mungkin saja dalam pemikiran siswa berbicara tentang hari berarti mengarah dalam situasi "1 minggu $=7$ hari"), jawaban kelompok 6 salah dalam membagi beras setiap hari. Hal ini menandakan bahwa siswa belum memahami konsep pembagian dan bilangan pecahan dengan baik.

Berikut ini merupakan hasil kerja dari tujuh kelompok dalam menyelesaikan LKS 1.

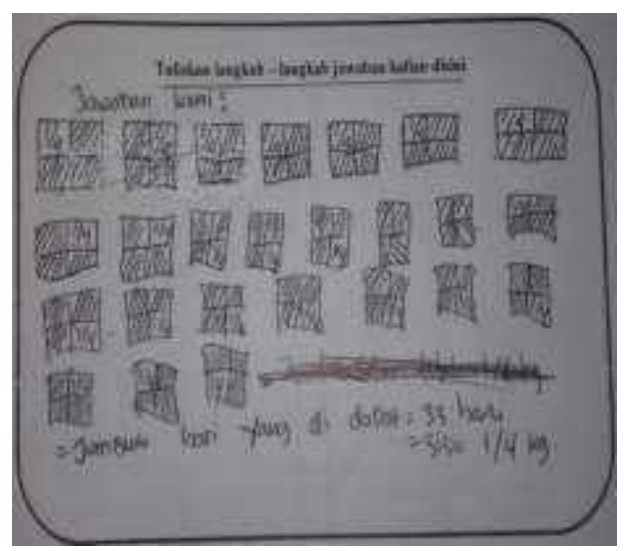

(a)

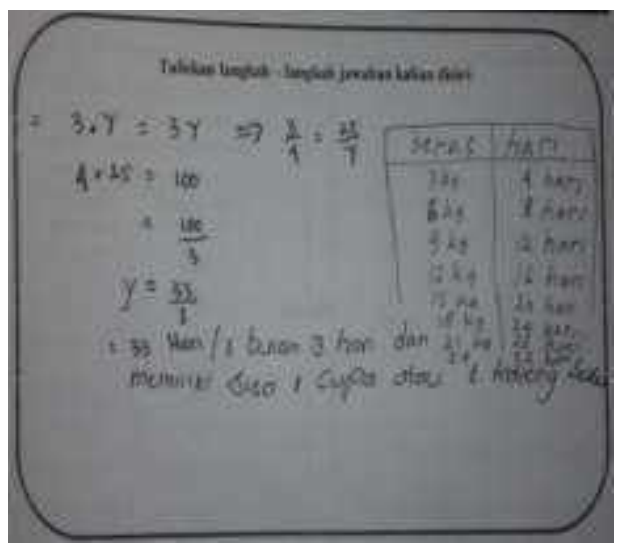

(b) 


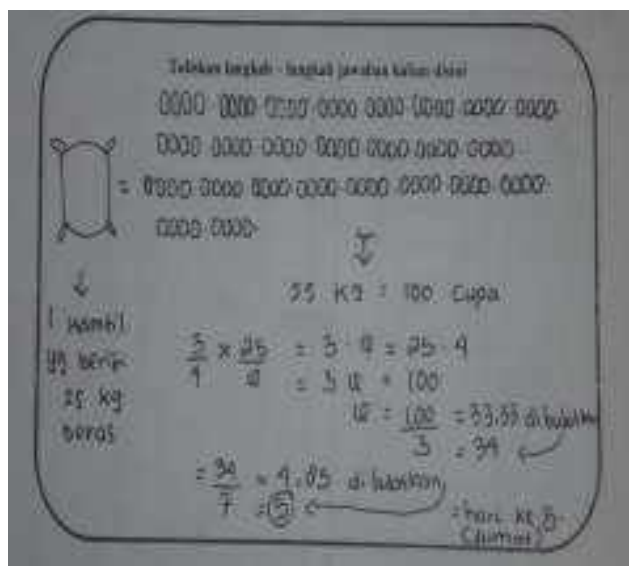

(c)

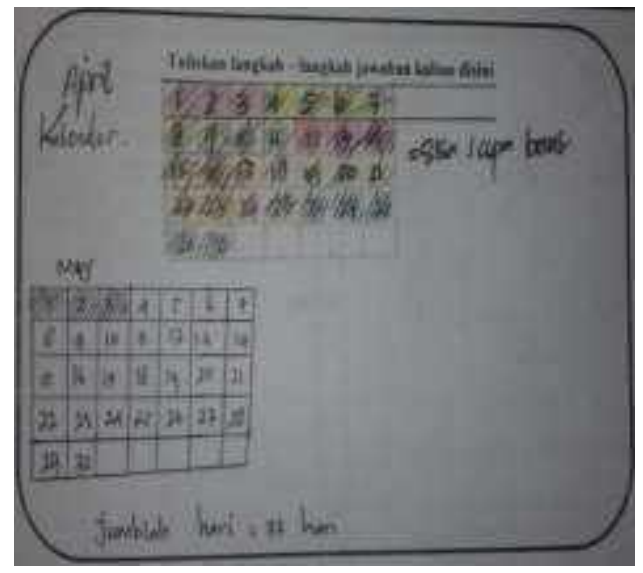

(e)

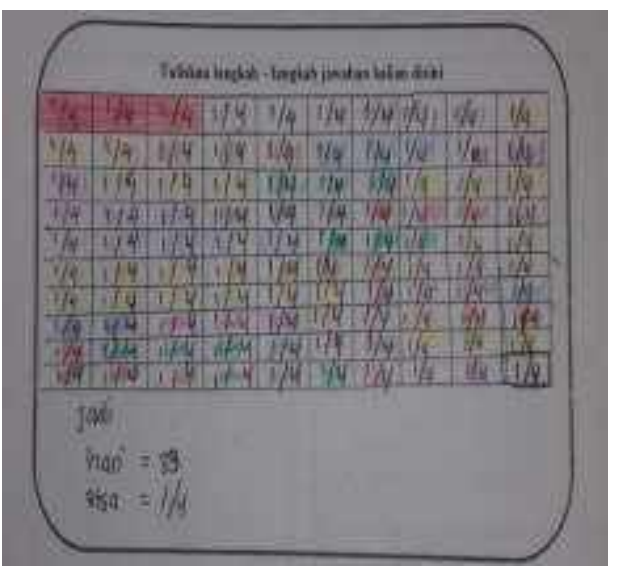

(d)

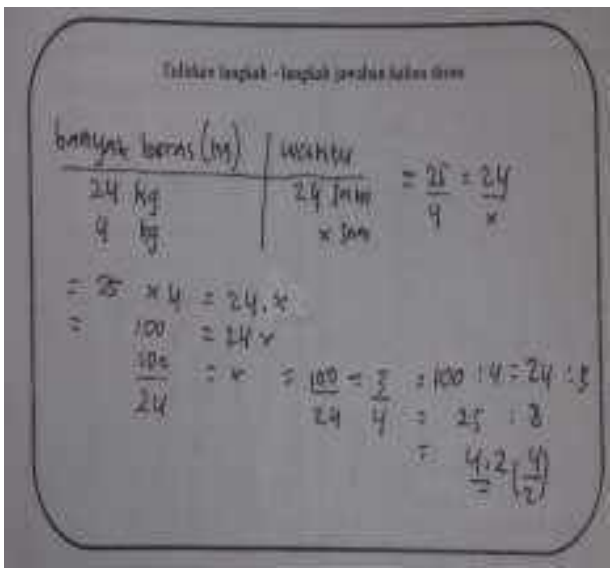

(f)

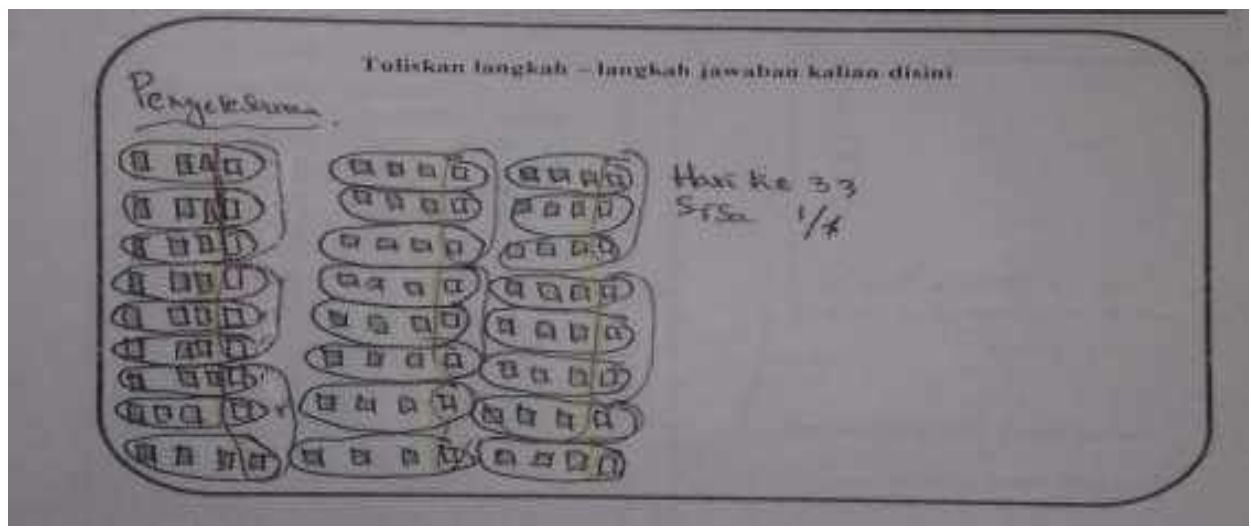

(g)

Gambar 16. Hasil Kerja Masing-masing Kelompok untuk LKS 1 (kelompok 1 (a), kelompok 2 (b), kelompok 3 (c), kelompok 4 (d), kelompok 5 (e), kelompok 6 (f), kelompok 7 (g)) 
Guru kemudian menjelaskan kembali tentang konsep pembagian dan bilangan pecahan serta bersama-sama dengan siswa membahas hasil kerja dari kelompok dan membuat kesimpulan dari berbagai jawaban siswa.

Tahap refleksi (Aktivitas pembelajaran 3)

Pada aktivitas ini, setelah siswa menggunakan berbagai macam cara dalam menyelesaikan masalah kontekstual pada LKS 1, guru memberikan LKS 2 dimana masalah kontekstual pada LKS 1 dapat diselesaikan dengan menggunakan persamaan matematika formal (formal mathematics). Dari jawaban benar yang diberikan kelompok maka dapat diketahui bahwa siswa sudah memahami materi perbandingan senilai. Pada tahap ini juga bersama-sama dengan siswa melakukan konstruksi pengetahuan matematis berdasarkan aktivitas membagi beras menuju materi Perbandingan Senilai serta mengaitkan materi lain yang ada hubungannya.

Tahap akhir dan penyimpulan

Bersama-sama membuat kesimpulan dan menyempurnakan jawaban yang kurang tepat dari aktivitas dilakukan menuju materi Perbandingan Senilai. Siswa diberikan tes hasil belajar untuk dikerjakan secara mandiri dalam mengembangkan pengetahuan dan konsep yang telah dipelajari. Gambar di bawah ini merupakan iceberg pembelajaran materi Perbandingan Senilai yang telah dilaksanakan. 


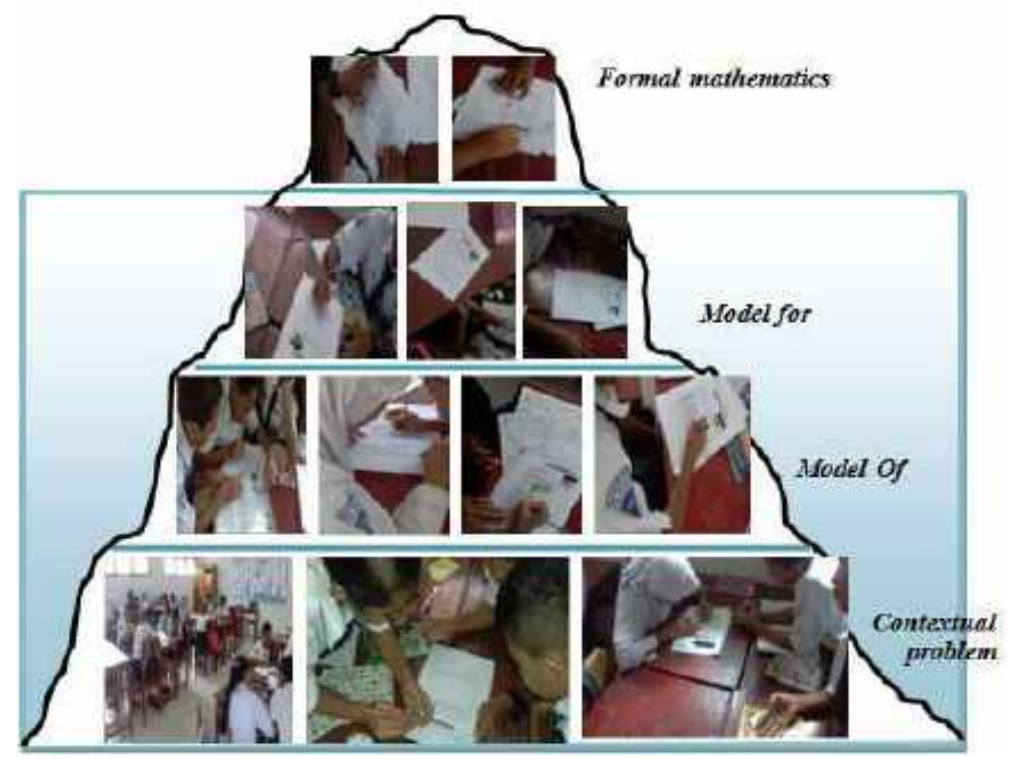

Gambar 17. Iceberg Pembelajaran Perbandingan Senilai

Iceberg pembelajaran tidak terlepas dari learning trajectory yang memuat rute perjalanan materi pembelajaran. Learnning trajectory yang dihasilkan adalah lintasan belajar siswa dalam memahami materi Perbandingan Senilai yang berawal dari penyelesaian masalah kontekstual membagi beras secara adil hingga tahap formal penyelesaian Perbandingan Senilai. Dalam bagian ini, terdapat tiga tahapan yang dilalui siswa, yaitu pembagian dalam bentuk unit-unit geometri, mengaplikasikan konsep bilangan pecahan senilai pada penulisan hasil membagi beras dan perhitungan matematika formal. Dari semua aktivitas yang dilalui siswa dinyatakan bahwa siswa dapat memahami materi Perbandingan Senilai berdasarkan learning trajectory yang dihasilkan dan siswa memberikan beragam strategi dalam menyelesaikan permasalahannya baik pada tahap contextual problem, model of, model for dan formal mathematics. 
Learning trajectory menggunakan pendekatan PMRI dengan konteks budaya Masohi pada materi Perbandingan Senilai ditunjukan pada gambar berikut ini.

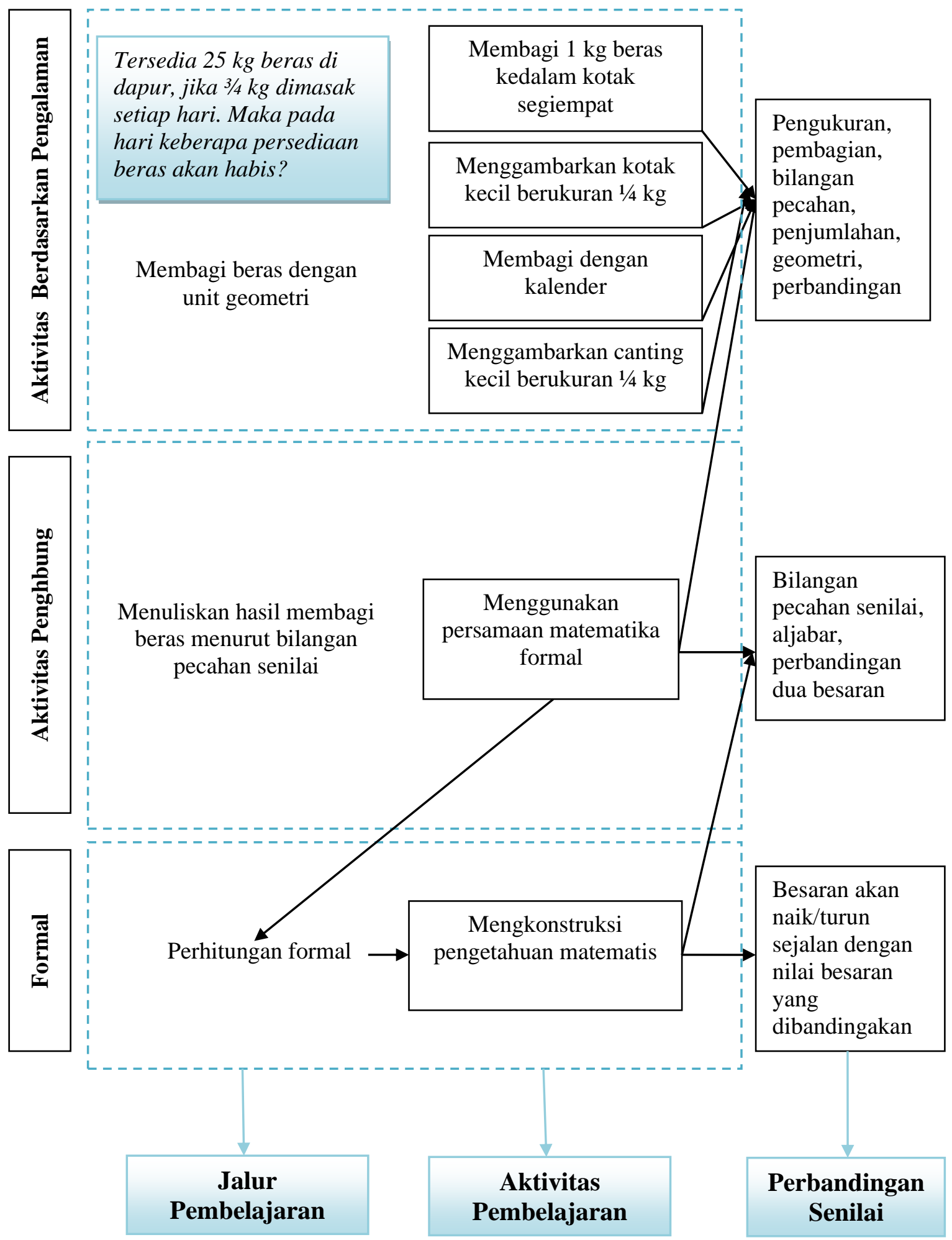




\section{Gambar 18. Learning Trajectory Pembelajaran Perbandingan Senilai}

\section{Hasil tahap retrospective analysis}

Dari hasil ujicoba perangkat pembelajaran pada kelas teaching experiment, diperoleh data aktivitas siswa, data kemampuan guru mengelola pembelajaran, data hasil belajar, serta data respon siswa. Revisi perangkat pada hasil ujicoba didasarkan pada deskripsi aktivitas siswa, kemampuan guru mengelola pembelajaran, tes hasil belajar dan respon siswa. Data yang diperoleh pada saat ujicoba dianalisis, kemudian hasilnya digunakan sebagai bahan pertimbangan untuk merevisi prototipe 3 menjadi perangkat final.

Analisis data hasil ujicoba dimaksudkan untuk mendeskripsikan proses pelaksanaan kegiatan belajar mengajar selama ujicoba yang meliputi aktivitas siswa selama pembelajaran berlangsung, kemampuan guru mengelola pembelajaran, respon siswa terhadap pembelajaran dan tes hasil belajar. Data yang dianalisis adalah sebagai berikut.

\section{a) Aktivitas siswa selama pembelajaran}

Pengamatan terhadap aktivitas siswa selama kegiatan pembelajaran menggunakan lembar observasi aktivitas siswa. Pengamatan dilakukan oleh seorang pengamat terhadap 4 siswa yang dilakukan sejak dimulai hingga berakhir kegiatan pembelajaran. Setiap 4 menit pengamat mengamati aktivitas siswa yang dominan dan 1 menit berikutnya pengamat menuliskan hasil pengamatannya. 
Aktivitas siswa selama pembelajaran pada penelitian ini dapat dilihat pada tabel di bawah ini.

Tabel 15. Aktivitas Siswa Selama Kegiatan Pembelajaran

\begin{tabular}{|l|c|c|c|}
\hline \multirow{2}{*}{\multicolumn{1}{|c|}{ Kategori Pengamatan }} & \multicolumn{3}{|c|}{$\begin{array}{c}\text { Persentase Aktivitas Siswa } \\
\text { dalam } \\
\text { Pembelajaran (\%) }\end{array}$} \\
\cline { 2 - 4 } & RPP I & RPP II & RPP III \\
\hline $\begin{array}{l}\text { Mendengarkan atau memperhatikan } \\
\text { penjelasan guru atau teman }\end{array}$ & 13,75 & 11,25 & 10 \\
\hline $\begin{array}{l}\text { Membaca atau memahami masalah } \\
\text { kontesktual dibuku siswa atau LKS }\end{array}$ & 10 & 8,75 & 10 \\
\hline $\begin{array}{l}\text { Menyelesaikan masalah atau } \\
\text { menemukan cara penyelesaian masalah }\end{array}$ & 27,5 & 33,75 & 35 \\
\hline $\begin{array}{l}\text { Membandingkan jawaban dalam } \\
\text { diskusi kelompok atau diskusi kelas }\end{array}$ & 27,5 & 27,5 & 26,25 \\
\hline $\begin{array}{l}\text { Bertanya atau menyampaikan pendapat } \\
\text { atau ide kepada guru atau teman }\end{array}$ & 10 & 7,5 & 6,25 \\
\hline $\begin{array}{l}\text { Menarik kesimpulan suatu konsep atau } \\
\text { prosedur }\end{array}$ & 5 & 5 & 6,25 \\
\hline $\begin{array}{l}\text { Perilaku siswa yang tidak relevan } \\
\text { dengan KBM }\end{array}$ & 6,25 & 6,25 & 6,25 \\
\hline
\end{tabular}

Berdasarkan tabel di atas, peninjauan terhadap aktivitas siswa untuk setiap pertemuan memiliki aspek pengamatan yang berada di luar batas toleransi waktu ideal yang ditentukan. Pada pertemuan I, terdapat satu aktivitas yang berada diluar batas toleransi waktu ideal yang ditetapkan. Pada pertemuan II, terdapat dua aktivitas diluar batas toleransi waktu ideal yang ditetapkan. Pada pertemuan III, terdapat dua aktivitas diluar batas toleransi waktu ideal yang ditetapkan. Aktivitas yang diluar dari batas toleransi waktu ideal adalah menyelesaikan masalah atau menemukan cara penyelesaian masalah $33,75 \%$ dan $35 \%$ (pertemuan II dan III) dengan batas toleransi waktu ideal $22 \%$ - $32 \%$ dan perilaku siswa yang tidak 
relevan $6,25 \%$ (pertemuan I, II, dan III) dengan batas toleransi waktu ideal $0 \%-5 \%$.

Berdasarkan hasil ini, aspek "menyelesaikan masalah atau menemukan cara penyelesaian masalah, dan perilaku siswa yang tidak relevan" perlu digunakan sebagai pertimbangan untuk melakukan revisi terhadap perangkat pembelajaran yang digunakan. Perangkat pembelajaran yang direvisi dalam hal ini adalah Rencana Pelaksanaan Pembelajaran. Revisi tersebut dilakukan dengan menyesuaikan perkiraan waktu beberapa kegiatan pada RPP dengan pelaksanaan di lapangan. Adapun revisi-revisi tersebut dapat dilihat pada Tabel 17.

\section{b) Kemampuan guru mengelola pembelajaran}

Hasil pengamatan kemampuan guru mengelola pembelajaran dengan pendekatan PMRI pada materi Perbandingan Senilai pada penelitian ini dapat di lihat pada tabel berikut.

Tabel 16. Hasil Pengamatan Kemampuan Guru Mengelola Pembelajaran

\begin{tabular}{|c|l|c|c|c|}
\hline No & \multicolumn{1}{|c|}{ Indikator yang diamati } & \multicolumn{3}{|c|}{ Pertemuan } \\
\cline { 3 - 5 } & & RPP I & RPP II & RPP III \\
\hline I. & PENDAHULUAN & 4 & 4 & 4 \\
\hline 1. & Memeriksa kesiapan siswa & 3 & 4 & 4 \\
\hline 2. & Melakukan kegiatan apersepsi & & & \\
\hline 3. & $\begin{array}{l}\text { Menyampaikan tujuan yang } \\
\text { akan dicapai dalam proses } \\
\text { pembelajaran }\end{array}$ & 4 & 4 & 4 \\
\hline 4. & $\begin{array}{l}\text { Memberikan pemanasan berupa } \\
\text { masalah kontekstual yang } \\
\text { berhubungan dengan konsep } \\
\text { materi pembelajaran }\end{array}$ & 3 & 3 & 4 \\
\hline II. & $\begin{array}{l}\text { KEGIATAN INTI } \\
\text { PEMBELAJARAN }\end{array}$ & & & \\
\hline 5. & Memberikan contoh masalah & & & \\
\hline
\end{tabular}




\begin{tabular}{|c|c|c|c|c|}
\hline & $\begin{array}{l}\text { kontekstual yang berhubungan } \\
\text { dengan materi pembelajaran }\end{array}$ & 3 & 4 & 4 \\
\hline 6. & $\begin{array}{l}\text { Memberikan Lembar Kerja } \\
\text { Siswa dengan masalah } \\
\text { kontekstual yang berhubungan } \\
\text { dengan materi pembelajaran } \\
\text { kepada masing-masing } \\
\text { kelompok }\end{array}$ & 3 & 4 & 4 \\
\hline 7. & $\begin{array}{l}\text { Memberikan kesempatan kepada } \\
\text { siswa yang mewakili } \\
\text { kelompoknya masing-masing } \\
\text { untuk menyampaikan hasil } \\
\text { diskusi didepan kelas }\end{array}$ & 4 & 4 & 4 \\
\hline 8. & $\begin{array}{l}\text { Bersama siswa membahas } \\
\text { penyelesaian masalah yang } \\
\text { berhubungan dengan materi } \\
\text { pembelajaran }\end{array}$ & 4 & 4 & 4 \\
\hline 9. & Memberikan umpan balik & 3 & 4 & 4 \\
\hline IV & PENUTUP & & & \\
\hline 10. & $\begin{array}{l}\text { Melengkapi jawaban siswa yang } \\
\text { kurang tepat }\end{array}$ & 4 & 4 & 4 \\
\hline 11. & $\begin{array}{l}\text { Memberikan review secara } \\
\text { umum, menyampaikan inti } \\
\text { pembelajaran pada siswa, } \\
\text { menyampaikan materi pelajaran } \\
\text { berikutnya, memotivasi siswa } \\
\text { untuk proses pembelajaran } \\
\text { berikutnya }\end{array}$ & 4 & 4 & 4 \\
\hline 12. & $\begin{array}{l}\text { Memberikan penilaian berupa } \\
\text { tes hasil belajar }\end{array}$ & 4 & 4 & 4 \\
\hline
\end{tabular}

Pada pertemuan yang pertama, aktivitas guru dalam mengelola pembelajaran pada umumnya bernilai baik. Namun ada indikator yang memperoleh kategori nilai (3), yaitu pada indikator ke- 2, 4, 5, 6, dan 9. Hal ini terjadi karena guru belum terbiasa menerapkan pembelajaran dengan menggunakan pendekatan PMRI. Untuk mengantisipasi hal tersebut, setelah selesai kegiatan pembelajaran pada pertemuan pertama, peneliti berdiskusi dengan guru mitra 
sehingga pada pertemuan berikutnya aspek ke- 2, 4, 5, 6, dan 9 bernilai (4).

Pada pertemuan kedua, aktivitas guru dalam mengelola pembelajaran pada umumnya bernilai baik. Namun masih ada indikator yang memperoleh kategori nilai (3), yaitu pada indikator ke- 4. Hal ini terjadi karena guru belum sepenuhnya menerapkan pembelajaran dengan menggunakan pendekatan PMRI. Sehingga untuk mengantisipasi hal tersebut, setelah selesai kegiatan pembelajaran pada pertemuan kedua, peneliti berdiskusi dengan guru mitra sehingga pada pertemuan berikutnya aspek ke- 4, bernilai (4).

Pada pertemuan ketiga, aktivitas guru dalam mengelola pembelajaran mengalami perubahan yang lebih baik dan bernilai baik. Hal ini disebabkan karena pertemuan sebelumnya peneliti telah berdiskusi dengan guru mitra mengenai hal-hal yang perlu diperbaiki dalam mengelola pembelajaran.

Berdasarkan analisis deskriptif terhadap kemampuan aktivitas guru mengelola pembelajaran, ternyata masih diperlukan sedikit revisi terhadap perangkat pembelajaran yang digunakan. Perangkat pembelajaran yang direvisi dalam hal ini adalah Rencana Pelaksanaan Pembelajaran. Revisi tersebut dilakukan dengan menyesuaikan perkiraan waktu beberapa kegiatan pada RPP dengan pelaksanaan di lapangan. 
Tabel 17. Revisi Rencana Pelaksanaan Pembelajaran

\begin{tabular}{|c|c|c|}
\hline Yang Direvisi & $\begin{array}{c}\text { Sebelum } \\
\text { Revisi }\end{array}$ & $\begin{array}{c}\text { Sesudah } \\
\text { Revisi }\end{array}$ \\
\hline $\begin{array}{ll}\text { RPP I } & \\
\text { a. Kegiatan Pendahuluan } \\
\text { - Membuka pelajaran dengan } \\
\text { - } \text { mengucapkan salam. } \\
\text { - Mengecek kehadiran siswa. } \\
\text { b. Kegiatan Inti } \\
\text { - Meminta perwakilan dari } \\
\\
\text { kelompok untuk melaporkan } \\
\quad \text { dan mempresentasikan hasil } \\
\text { diskusi. }\end{array}$ & $\begin{array}{l}2 \text { menit } \\
3 \text { menit } \\
8 \text { menit }\end{array}$ & $\begin{array}{l}1 \text { menit } \\
2 \text { menit } \\
10 \text { menit }\end{array}$ \\
\hline $\begin{array}{l}\text { RPP II } \\
\text { a. Kegiatan Pendahuluan } \\
\text { - } \text { Membuka pelajaran dengan } \\
\text { mengucapkan salam. } \\
\text { - } \text { Mengecek kehadiran siswa. } \\
\text { b. Kegiatan Inti } \\
\text { - Secara berkelompok } \\
\text { membaca dan melakukan } \\
\text { aktivitas diskusi kelompok. } \\
\text { a. Memahami konsep } \\
\text { perbandingan dua besaran } \\
\quad \text { atau lebih. } \\
\text { c. Menyelesaikan masalah } \\
\quad \text { kontekstual yang } \\
\text { diberikan pada LKS. } \\
\text { - Meminta perwakilan dari } \\
\text { kelompok untuk melaporkan } \\
\text { dan mempresentasikan hasil } \\
\text { diskusi. } \\
\text { - Meminta kelompok } \\
\text { pendengar untuk menanggapi } \\
\text { hasil diskusi temannya di } \\
\text { depan kelas. } \\
\text { Bersama sama membahas } \\
\text { hasil penyelesaian masalah } \\
\text { yang diberikan beserta } \\
\text { contoh perbandingan dua } \\
\text { besaran atau lebih. }\end{array}$ & $\begin{array}{l}3 \text { menit } \\
4 \text { menit }\end{array}$ & $\begin{array}{l}1 \text { menit } \\
2 \text { menit }\end{array}$ \\
\hline $\begin{array}{l}\text { c. Kegiatan Penutup } \\
\text { - Menyempurnakan jawaban } \\
\text { yang kurang tepat. } \\
\text { - Memberikan penilaian } \\
\text { berupa tes hasil belajar pada }\end{array}$ & $\begin{array}{l}2 \text { menit } \\
15 \text { menit }\end{array}$ & $\begin{array}{l}3 \text { menit } \\
12 \text { menit }\end{array}$ \\
\hline
\end{tabular}




\begin{tabular}{|c|c|c|}
\hline akhir pembelajaran. & & \\
\hline \multirow{5}{*}{$\begin{array}{l}\text { RPP III } \\
\text { a. Kegiatan Pendahuluan } \\
\text { - Membuka pelajaran dengan } \\
\text { mengucapkan salam. } \\
\text { - Mengecek kehadiran siswa. } \\
\text { - Mengingatkan kembali } \\
\text { materi perbandingan dua } \\
\text { besaran atau lebih. }\end{array}$} & & \\
\hline & 2 menit & 1 menit \\
\hline & 2 menit & 3 menit \\
\hline & 3 menit & 2 menit \\
\hline & & \\
\hline - Mengawali pembelajaran & 2 menit & 3 menit \\
\hline dengan memberikan masalah & & \\
\hline memasak $-\frac{3}{k g}$ setiap hari. & & \\
\hline iika tersedia 25 ka heras di & & \\
\hline dapur maka hari & & \\
\hline keberapakah persediaan & & \\
\hline berasnya akan habis? & & \\
\hline \multirow{10}{*}{$\begin{array}{l}\text { b. Kegiatan inti } \\
\text { - Secara berkelompok } \\
\text { membaca dan melakukan } \\
\text { aktivitas diskusi kelompok } \\
\text { d. Menyelesaikan masalah } \\
\text { kontekstual yang } \\
\text { diberikan pada LKS } \\
\text { - Meminta perwakilan dari } \\
\text { kelompok untuk melaporkan } \\
\text { dan mempresentasikan hasil } \\
\text { diskusi } \\
\text { - Meminta kelompok } \\
\text { pendengar untuk menanggapi } \\
\text { hasil diskusi temannya di } \\
\text { depan kelas } \\
\text { - Memberikan umpan balik }\end{array}$} & & \\
\hline & & \\
\hline & & \\
\hline & 13 menit & 10 menit \\
\hline & & \\
\hline & 10 menit & 12 menit \\
\hline & & \\
\hline & 3 menit & 4 menit \\
\hline & 3 mentl & 4 menit \\
\hline & 2 menit & 3 menit \\
\hline \multirow{4}{*}{$\begin{array}{l}\text { c. Kegiatan Penutup } \\
\text { - Meminta siswa untuk } \\
\text { menyimpulkan hasil } \\
\text { temuannya } \\
\text { - Menyempurnakan jawaban } \\
\text { yang kurang tepat } \\
\text { - Memberikan penilaian berupa } \\
\text { tes hasil belajar pada akhir } \\
\text { pembelajaran }\end{array}$} & & \\
\hline & 5 menit & 4 menit \\
\hline & 2 menit & 3 menit \\
\hline & & 12 menit \\
\hline
\end{tabular}

c) Respon siswa 
Dari angket respon siswa yang diisi oleh 27 siswa setelah mengikuti pembelajaran untuk materi Perbandingan Senilai menggunakan pendekatan PMRI, maka diperoleh hasil dengan rincian seperti pada Tabel-tabel di bawah ini.

Tabel 18. Persentase Perasaan Siswa Terhadap Komponen Mengajar

\begin{tabular}{|l|c|c|}
\hline \multicolumn{1}{|c|}{ Aspek yang direspon } & Senang & Tidak senang \\
\hline a. Materi pelajaran & $100 \%$ & $0 \%$ \\
b. LKS & $92,59 \%$ & $7,41 \%$ \\
c. Tes hasil belajar & $85,19 \%$ & $14,81 \%$ \\
d. Suasana belajar di kelas & $96,30 \%$ & $3,7 \%$ \\
e. Cara belajar & $100 \%$ & $0 \%$ \\
\hline
\end{tabular}

Tabel 19. Persentase Pendapat Siswa Terhadap Komponen Pembelajaran

\begin{tabular}{|l|c|c|}
\hline \multicolumn{1}{|c|}{ Keterangan } & Baru & Tidak baru \\
\hline a. Materi pelajaran & $85,19 \%$ & $14,81 \%$ \\
b. LKS & $96,30 \%$ & $3,7 \%$ \\
c. Tes hasil belajar & $96,30 \%$ & $3,7 \%$ \\
d. Suasana belajar di kelas & $88,88 \%$ & $11,12 \%$ \\
e. Cara belajar & $92,59 \%$ & $7,41 \%$ \\
\hline
\end{tabular}

Tabel 20. Persentase Pendapat Siswa tentang Pemahaman Bahasa yang Digunakan

\begin{tabular}{|l|c|c|}
\hline \multicolumn{1}{|c|}{ Aspek yang direspon } & Jelas & Tidak jelas \\
\hline a. LKS & $92,59 \%$ & $7,41 \%$ \\
b. Tes hasil belajar & $92,59 \%$ & $7,41 \%$ \\
\hline
\end{tabular}

Tabel 21. Persentase Pendapat Siswa tentang Penampilan (Tulisan, Ilustrasi atau Gambar dan Letak Gambar)

\begin{tabular}{|l|c|c|}
\hline \multicolumn{1}{|c|}{ Aspek yang direspon } & Tertarik & Tidak tertarik \\
\hline a. LKS & $96,30 \%$ & $3,7 \%$ \\
b. Tes hasil belajar & $96,30 \%$ & $3,7 \%$ \\
\hline
\end{tabular}

Berdasarkan hasil respon siswa di atas jika dihubungkan dengan kriteria pada Bab III, menunjukkan bahwa respon siswa 
terhadap komponen pembelajaran matematika menggunakan pendekatan PMRI adalah positif. Disamping itu siswa dapat pula memahami bahasa dan tertarik pada tampilan LKS. Dengan demikian, maka berdasarkan respon siswa positif (lebih besar 80\%), tidak perlu diadakan revisi terhadap perangkat pembelajaran.

\section{d) Tes hasil belajar}

(1) Validitas

Perhitungan validitas butir tes dapat dilihat pada Lampiran. Berdasarkan rumus korelasi product moment, diperoleh validitas setiap butir tes sebagai berikut.

Tabel 22. Hasil Validitas Butir Tes

\begin{tabular}{|c|c|c|}
\hline No soal & $\boldsymbol{r}_{\boldsymbol{x y}}$ & Tingkat Validitas \\
\hline $1 \mathrm{a}$ & 0,612 & Tinggi \\
\hline 1b & 0,600 & Tinggi \\
\hline $2 \mathrm{a}$ & 0,594 & Cukup \\
\hline $2 \mathrm{~b}$ & 0,442 & Cukup \\
\hline $3 \mathrm{a}$ & 0,602 & Tinggi \\
\hline $3 \mathrm{~b}$ & 0,600 & Tinggi \\
\hline $3 \mathrm{c}$ & 0,739 & Tinggi \\
\hline $3 \mathrm{~d}$ & 0,705 & Tinggi \\
\hline 4 & 0,746 & Tinggi \\
\hline $5 \mathrm{a}$ & 0,832 & Sangat tinggi \\
\hline $5 \mathrm{~b}$ & 0,731 & Tinggi \\
\hline $5 \mathrm{c}$ & 0,753 & Tinggi \\
\hline
\end{tabular}

(2) Reliabilitas

Berdasarkan perhitungan reliabilitas tes (Lampiran), diperoleh koefisien reliabilitas tes $\alpha=0,799$, hal ini berarti tes hasil belajar mempunyai reliabilitas yang tinggi. Dengan demikian tes hasil belajar dapat dipakai (tanpa revisi) untuk 
mengukur tingkat penguasaan siswa terhadap materi Perbandingan Senilai.

Hasil revisi perangkat pembelajaran ini setelah uji coba dapat dikategorikan baik atau valid. Dengan demikian, pengembangan perangkat pembelajaran menggunakan metode penelitian dan pengembangan dengan model design research, menghasilkan perangkat pembelajaran melalalui pendekatan PMRI yang baik atau valid untuk materi Perbandingan Senilai di kelas VII SMP. Perangkat pembelajaran tersebut meliputi Rencana Pelaksanaan Pembelajaran (RPP), Lembar Kerja Siswa (LKS). Instrumen penelitian yang meliputi tes hasil belajar, lembar observasi aktivitas siswa, lembar observasi kemampuan guru mengelola pembelajaran dan angket respon siswa. Perangkat pembelajaran, instrumen penelitian dapat dilihat pada daftar Lampiran.

\section{B. Analisis Deskriptif Hasil Penelitian}

Hasil penelitian yang akan dianalisis secara deskriptif adalah data aktivitas siswa selama pembelajaran, kemampuan aktivitas guru mengelola pembelajaran, respon siswa terhadap pembelajaran matematika menggunakan pendekatan Pembelajaran Matematika Realistik Indonesia serta hasil belajar siswa. Hasil analisis masing-masing data tersebut disajikan berikut ini.

\section{Aktivitas siswa selama pembelajaran}


Hasil pengamatan terhadap aktivitas siswa dalam pembelajaran setiap kali pertemuan selama tiga kali tatap muka dinyatakan dengan persentase. Hasil tersebut secara ringkas disajikan dalam Tabel 23 berikut ini.

Tabel 23. Aktivitas Siswa Selama Kegiatan Pembelajaran

\begin{tabular}{|l|c|c|c|c|}
\hline \multirow{2}{*}{ Kategori Pengamatan } & \multicolumn{2}{|c|}{$\begin{array}{c}\text { Presentase Aktivitas Siswa } \\
\text { dalam Pembelajaran (\%) }\end{array}$} & $\begin{array}{c}\text { Presentase } \\
\text { rata-rata } \\
\text { (\%) }\end{array}$ \\
\cline { 2 - 4 } & RPP I & RPP II & RPP III & \\
\hline $\begin{array}{l}\text { Mendengarkan atau } \\
\text { memperhatikan } \\
\text { penjelasan guru atau } \\
\text { teman }\end{array}$ & 13,75 & 12,5 & 13,75 & 13,33 \\
\hline $\begin{array}{l}\text { Membaca atau } \\
\text { memahami masalah } \\
\text { kontekstual di buku } \\
\text { siswa atau LKS }\end{array}$ & 10 & 10 & 10 & \\
\hline $\begin{array}{l}\text { Menyelesaikan masalah } \\
\text { atau menemukan cara } \\
\text { penyelesaian masalah }\end{array}$ & 27,5 & 27,5 & 27,5 & 27,5 \\
\hline $\begin{array}{l}\text { Membandingkan } \\
\text { jawaban dalam diskusi } \\
\text { kelompok atau diskusi } \\
\text { kelas }\end{array}$ & 30 & 33,75 & 32,5 & 32,08 \\
\hline $\begin{array}{l}\text { Bertanya atau } \\
\text { menyampaikan } \\
\text { pendapat atau ide } \\
\text { kepada guru atau teman }\end{array}$ & 10 & 7,5 & 7,5 & 8,33 \\
\hline $\begin{array}{l}\text { Menarik kesimpulan } \\
\text { suatukonsep atau } \\
\text { prosedur }\end{array}$ & 5 & 5,75 & 3,75 & 3,75 \\
\hline $\begin{array}{l}\text { Perilaku siswa yang } \\
\text { tidak relevan dengan } \\
\text { KBM }\end{array}$ & 3,75 & & \\
\hline
\end{tabular}

Berdasarkan tabel di atas dan mengacu pada kriteria waktu ideal aktivitas siswa dalam pembelajaran (Tabel 4 pada BAB III), maka dapat disimpulkan bahwa aktivitas siswa untuk masingmasing kategori pada setiap RPP adalah efektif.

\section{Kemampuan guru mengelola pembelajaran}


Berdasarkan hasil pengamatan mengenai kemampuan guru dalam mengelola pembelajaran matematika dengan pendekatan PMRI dapat dilihat pada Tabel 24 di bawah ini.

Tabel 24. Hasil Pengamatan Kemampuan Guru Mengelola Pembelajaran

\begin{tabular}{|c|c|c|c|c|}
\hline \multirow[t]{2}{*}{ No } & \multirow[t]{2}{*}{ Indikator } & \multicolumn{3}{|c|}{ Pertemuan } \\
\hline & & RPP I & RPP II & RPP III \\
\hline I. & PENDAHULUAN & & & \\
\hline 1. & Memeriksa kesiapan siswa & 4 & 4 & 4 \\
\hline 2. & Melakukan kegiatan apersepsi & 3 & 4 & 4 \\
\hline 3. & $\begin{array}{l}\text { Menyampaikan tujuan yang } \\
\text { akan dicapai dalam proses } \\
\text { pembelajaran }\end{array}$ & 4 & 4 & 4 \\
\hline 4. & $\begin{array}{l}\text { Memberikan pemanasan } \\
\text { berupa masalah kontekstual } \\
\text { yang berhubungan dengan } \\
\text { konsep materi pembelajaran. }\end{array}$ & 3 & 3 & 4 \\
\hline II & $\begin{array}{l}\text { KEGIATAN INTI } \\
\text { PEMBELAJARAN }\end{array}$ & & & \\
\hline 5. & $\begin{array}{l}\text { Memberikan contoh masalah } \\
\text { kontekstual yang berhubungan } \\
\text { dengan materi pembelajaran. }\end{array}$ & 3 & 4 & 4 \\
\hline 6. & $\begin{array}{l}\text { Memberikan Lembar Kerja } \\
\text { Siswa dengan masalah } \\
\text { kontekstual yang berhubungan } \\
\text { dengan materi pembelajaran } \\
\text { kepada masing-masing } \\
\text { kelompok. }\end{array}$ & 3 & 4 & 4 \\
\hline 7. & $\begin{array}{l}\text { Memberikan } \\
\text { kesempatankepada siswa yang } \\
\text { mewakili kelompoknya } \\
\text { masing-masing untuk } \\
\text { menyampaikan hasil diskusi } \\
\text { didepan kelas. }\end{array}$ & 4 & 4 & 4 \\
\hline 8. & $\begin{array}{l}\text { Bersama siswa membahas } \\
\text { penyelesaian masalah yang } \\
\text { berhubungan dengan materi } \\
\text { pembelajaran }\end{array}$ & 4 & 4 & 4 \\
\hline 9. & Memberikan umpan balik. & 3 & 4 & 4 \\
\hline $1 \mathrm{~V}$ & PENUTUP & & & \\
\hline 10. & $\begin{array}{l}\text { Melengkapi jawaban siswa } \\
\text { yang kurang tepat }\end{array}$ & 4 & 4 & 4 \\
\hline 11. & $\begin{array}{l}\text { Memberikan review secara } \\
\text { umum, menyampaikan inti } \\
\text { pembelajaran pada siswa, } \\
\text { menyampaikan materi }\end{array}$ & 4 & 4 & 4 \\
\hline
\end{tabular}




\begin{tabular}{|c|c|c|c|c|}
\hline & $\begin{array}{l}\text { pelajaran berikutnya, } \\
\text { memotivasi siswa untuk proses } \\
\text { pembelajaran berikutnya. }\end{array}$ & & & \\
\hline \multirow[t]{2}{*}{12.} & $\begin{array}{l}\text { Memberikan penilaian berupa } \\
\text { tes hasil belajar }\end{array}$ & 4 & 4 & 4 \\
\hline & Rata-rata & 3,58 & 3,92 & 4,00 \\
\hline
\end{tabular}

Berdasarkan kriteria kemampuan guru mengelola pembelajaran yang diuraikan pada bab III, kemampuan guru mengelola pembelajaran pada pertemuan pertama, kedua, dan ketiga yang di amati oleh satu orang pengamat mencapai kategori "baik", yaitu terletak dalam interval 3,50 $\leq$ TKG $<$ 4,50. Hal ini menunjukkan bahwa kemampuan guru dalam mengelola pembelajaran matematika menggunakan pendekatan PMRI adalah efektif.

\section{Hasil respon siswa}

Berdasarkan angket respon siswa yang diisi oleh 27 siswa setelah mengikuti pembelajaran untuk materi Perbandingan Senilai dengan pendekatan PMRI, maka diperoleh hasil dengan rincian seperti pada Tabel-tabel di bawah ini.

Tabel 25. Persentase Perasaan Siswa Terhadap Komponen Mengajar

\begin{tabular}{|c|c|c|}
\hline Aspek yang direspon & Senang & Tidak senang \\
\hline $\begin{array}{ll}\text { a. } & \text { Materi pelajaran } \\
\text { b. } & \text { LKS } \\
\text { c. Tes hasil belajar } \\
\text { d. } & \text { Suasana belajar di kelas } \\
\text { e. } & \text { Cara belajar } \\
\end{array}$ & $\begin{array}{c}100 \% \\
92,59 \% \\
85,19 \% \\
96,30 \% \\
100 \% \\
\end{array}$ & $\begin{array}{c}0 \% \\
7,41 \% \\
14,81 \% \\
3,7 \% \\
0 \% \\
\end{array}$ \\
\hline
\end{tabular}

\section{Tabel 26. Persentase Pendapat Siswa Terhadap Komponen} Pembelajaran 


\begin{tabular}{|l|c|c|}
\hline \multicolumn{1}{|c|}{ Keterangan } & Baru & Tidak baru \\
\hline a. Materi pelajaran & $85,19 \%$ & $14,81 \%$ \\
b. LKS & $96,30 \%$ & $3,7 \%$ \\
c. Tes hasil belajar & $96,30 \%$ & $3,7 \%$ \\
d. Suasana belajar di kelas & $88,88 \%$ & $11,12 \%$ \\
e. Cara belajar & $92,59 \%$ & $7,41 \%$ \\
\hline
\end{tabular}

Tabel 27. Persentase Pendapat Siswa tentang Pemahaman Bahasa yang digunakan

\begin{tabular}{|c|c|c|}
\hline Aspek yang direspon & Jelas & Tidak jelas \\
\hline a. LKS & $92,59 \%$ & $7,41 \%$ \\
\hline b. Tes hasil belajar & $92,59 \%$ & $7,41 \%$ \\
\hline
\end{tabular}

Tabel 28. Persentase Pendapat Siswa tentang Penampilan (Tulisan, Ilustrasi atau Gambar dan Letak Gambar)

\begin{tabular}{|l|c|c|}
\hline \multicolumn{1}{|c|}{ Aspek yang direspon } & Tertarik & Tidak tertarik \\
\hline a. LKS & $96,30 \%$ & $3,7 \%$ \\
b. Tes hasil belajar & $96,30 \%$ & $3,7 \%$ \\
\hline
\end{tabular}

Berdasarkan data di atas terlihat bahwa lebih dari $80 \%$ siswa senang terhadap setiap komponen pembelajaran dan menyatakan baru menerima pendekatan PMRI. Dari segi pemahaman bahasa pada LKS dan tes hasil belajar lebih dari $90 \%$ siswa dapat memahaminya, selain itu lebih dari $95 \%$ juga siswa tertarik pada penampilan LKS dan tes hasil belajar. Dengan demikian respon siswa terhadap komponen pembelajaran matematika menggunakan pendekatan PMRI adalah positif.

\section{Hasil belajar siswa}

Pada penelitian ini, penilaian hasil belajar dilakukan melalui tes hasil belajar secara tertulis yang dilaksanakan pada akhir 
pembelajaran. Data hasil belajar siswa kelas teaching experiment dilihat pada Tabel 29 berikut.

\section{Tabel 29. Hasil Belajar Siswa Kelas Uji Coba}

\begin{tabular}{|l|c|}
\hline \multicolumn{1}{|c|}{ Keterangan } & Kelas uji coba \\
\hline Rata-rata hasil belajar siswa & \\
Tes Hasil Belajar I (Skor maksimal 15) & 10,89 \\
Tes Hasil Belajar II (Skor maksimal 24) & 16,67 \\
Tes Hasil Belajar III (Skor maksimal 33) & 23,48 \\
\hline Banyak siswa yang tuntas belajar & 23 dari 27 siswa \\
\hline Persentase banyak siswa yang tuntas belajar & $85,19 \%$ \\
\hline Ketuntasan belajar secara klasikal & Tuntas \\
\hline
\end{tabular}

Berdasarkan tabel di atas terlihat bahwa untuk kelas ujicoba pada tahap teaching experiment ketuntasan belajar secara klasikal tergolong tuntas.

Dengan memperhatikan uraian tabel-tabel di atas maka pencapaian keefektifan pembelajaran matematika menggunakan pendekatan PMRI ditentukan berdasarkan ketuntasan belajar secara klasikal, kemampuan guru dalam mengelola pembelajaran, aktivitas siswa selama pembelajaran dan respon siswa terhadap pembelajaran dapat dilihat pada Tabel 30 berikut.

Tabel 30. Pencapaian Keefektifan Pembelajaran Matematika Realistik Indonesia

\begin{tabular}{|c|l|c|c|}
\hline No & \multicolumn{1}{|c|}{ Aspek Kategori } & Keterangan & Kesimpulan \\
\hline 1. & Ketuntasan belajar secara klasikal & Tuntas & Efektif \\
2. & Kemampuan guru mengelola & Efektif & \\
& pembelajaran & & \\
3. & Aktivitas siswa & Efektif & \\
4. & Respon siswa & Positif & \\
\hline
\end{tabular}


Tabel di atas menunjukan bahwa pendekatan PMRI efektif untuk mengajarkan materi Perbandingan Senilai. Kriteria pembelajaran yang valid terlihat pada Tabel 31 dibawah ini.

Tabel 31. Kriteria Perangkat Pembelajaran yang Valid

\begin{tabular}{|c|l|c|c|}
\hline No & \multicolumn{1}{|c|}{ Aspek Kategori } & Keterangan & Kesimpulan \\
\hline 1. & Aktivitas siswa & Efektif & Valid \\
2. & Kemampuan guru mengelola & Efektif & \\
& pembelajaran & Positif & \\
3. & Respon siswa & Valid dan reliabel & \\
4. & Tes hasil belajar & \multicolumn{2}{c}{} \\
\hline
\end{tabular}

Kriteria perangkat pembelajaran yang praktis ditunjukkan dalam lembar pengamatan kemampuan guru dalam mengelola pembelajaran dan aktivitas siswa dalam pembelajaran. Berdasarkan hasil pengamatan terhadap kemampuan guru dalam mengelola pembelajaran dan aktivitas siswa dalam pembelajaran yang sudah dikategorikan baik, maka perangkat pembelajaran ini dapat dikatakan praktis. 


\section{BAB V}

\section{KESIMPULAN DAN SARAN}

\section{A. Kesimpulan}

Berdasarkan proses pengembangan perangkat dengan memperhatikan dugaan lintasan belajar siswa menggunakan metode penelitian dan pengembangan (reseacrh \& development) pada model desain pembelajaran (design research), dapat disimpulkan beberapa hal sebagai berikut:

1. Lintasan belajar siswa yang berkembang dari tahap informal ke tahap formal untuk memahami materi Perbandingan Senilai berawal dari contextual problem dapat dilihat pada pengembangan model. Pada level model of, siswa mampu menggambarkan bentuk unit-unit geometri untuk membagi beras yang mengacu pada konsep pengukuran, pembagian, bilangan pecahan, penjumlahan, geometri, perbandingan. Pada level model for, siswa mampu menyelesaikan masalah kontekstual dengan menggunakan persamaan matematika formal serta mampu menuliskan hasil membagi beras dalam bentuk tabel menurut pecahan senilai seperti diarahkan oleh guru yang mengacu pada konsep bilangan pecahan senilai dan perbandingan dua besaran atau lebih. Setelah pencapaian beberapa konsep dasar untuk memahami materi Perbandingan Senilai, siswa menyelesaikan persoalan masalah kontektual tersebut pada level formal mathematics dengan menggunakan persamaan matematika formal, mampu mengkonstruksi pengetahuan dan menyimpulkan 
materi pembelajaran Perbandingan Senilai berdasarkan aktivitas pembelajaran yang dilakukan.

2. Perangkat pembelajaran pada materi perbandingan senilai dikembangkan dengan menggunakan model design research yang dimodifikasi. Pengembangan perangkat pembelajaran dengan model ini terdiri dari 3 tahap yaitu: tahap preliminary design, tahap teaching experiment, dan tahap retrospective analysis. Dengan menggunakan model ini, dihasilkan perangkat pembelajaran yang valid untuk materi Perbandingan Senilai dengan pendekatan Pembelajaran Matematika Realistik Indonesia. Perangkat pembelajaran yang dihasilkan (terlampir pada Lampiran) meliputi: Rencana Pelaksanaan Pembelajaran (RPP), Lembar Kerja Siswa (LKS), dan Tes Hasil Belajar (THB).

3. Perangkat pembelajaran praktis untuk mengajarkan materi Perbandingan Senilai. Hal ini ditunjukkan dari hasil pengamatan kemampuan guru dalam mengelola pembelajaran dan aktivitas siswa dalam pembelajaran yang efektif.

4. Pembelajaran Matematika Realistik Indonesia efektif untuk mengajarkan materi Perbandingan Senilai di kelas VII SMP. Hal ini ditunjukkan oleh:

a. Kemampuan guru mengelola pembelajaran: efektif;

b. Aktivitas siswa: efektif;

c. Ketuntasan belajar secara klasikal: $85,19 \%$ siswa tuntas 
belajar individual;

d. Respon siswa terhadap pembelajaran: positif.

\section{B. Saran}

1. Peneliti yang akan melakukan penelitian dengan menggunakan model ini, disarankan untuk mengkaji berbagai literatur yang relevan, khususnya budaya setempat yang terkait dengan materi pembelajaran secara lebih mendalam sehingga kesalahan-kesalahan dalam proses mendesain dugaan lintasan belajar dapat diminimalkan.

2. Dari data hasil penelitian ini, maka disarankan kepada guru matematika untuk mengembangkan perangkat pembelajaran dengan menggunakan pendekatan Pembelajaran Matematika Realistik Indonesia untuk materi yang lain. 


\section{DAFTAR PUSTAKA}

Akker, J. V. 1999. Design Approaches and Tools in Education and Training. Dordrecht: Kluwer Academic Publishers.

Arikunto, Suharsimi. 2001. Dasar-Dasar Evaluasi Pendidikan (Edisi Revisi). Bumi Aksara.

Bardsley. 2006. Pre-Kindergarten Teacher's and Understanding of Hypothetical Learning Trajectories in Mathematics Education. Utrecth : University of Utrecht.

Budaya Maluku. http://wikipedia.org/wiki/Budaya (download tanggal 8 Maret 2017).

De Lange, J. 1987. Mathematics, insight and meaning. Utrecht: OW \&OC.

Depdiknas 2005. Undang Undang Republik Indonesia No. 14 Tahun 2005 Tentang Guru dan Dosen. Available at : [http://www.depdiknas.go.id/inlink.php?to=guru-dosen]. Retrieved On July 1st, 2006.

Eggen, P.D \& Kauchak, D.P. 1988. Strategies for teacher:Teaching Content and Thinking Skill. Allyn and Bacon: Boston.

Gravemeijer, K. (1994). Developing Realistic Mathematic Education.Utrecht: Freudenthal Institute.

Gravemeijer, K \& Cobb, P. 2006. Design Research From A Learning Design Perspective artikel dalam Educa-tional Design Research, pp. 17-55.

Hasratuddin. 2002. Pembelajaran Matematika Unit Geometri Dengan Pendekatan Realistik di SLTP N 6 Medan. Tesis. PPS UNESA Surabaya.

Ibrahim, Muslimin. 2002. Pengembangan Perangkat Pembelajaran. Direktorat Pendidikan Lanjutan Pertama, Dirjend Pendidikan Dasar dan Menengah. Jakarta: Depdiknas.

Ilma, Ratu 2008. Peningkatan Kemampuan Mengajar Matematika menggunakan Pendekatan Pendidikan Matematika Realistik Indonesia (PMRI) di Sekolah Ujicoba PMRI Palembang. Prosiding Keonferensi Nasional Matematika XIV.

Kementerian Pendidikan dan Kebudayaan 2013. Kurikulum Matematika 2013. Jakarta: Kemendikbud. 
La Siara. 2004. Pengembangan Perangkat Pembelajaran dengan Pendekatan Realistik untuk Topik Kesebangunan di kelas 3 SLTPN 22 Surabaya. Tesis PPs Unesa. Surabaya.

Laurens, Theresia. 2016. Analisis Etnomatematika dan Penerapannya dalam Meningkatkan Kualitas Pembelajaran. Ambon : FKIP Universitas Pattimura.

Mudhofir. 1987. Teknologi Instruksional. Bandung: Remaja Rosdakarya.

Nur, M. 1987. Pengantar Teori Tes. Depdikbud Dirjen Dikti. P2PTK. Jakarta.

Sabardin. 2004. "Pengembangan Perangkat Pembelajaran dengan Pendekatan Matematika Realistik untuk Topik Persegipanjang dan Persegi di Kelas 1 SMP Negeri 5 Bau-bau Sulawesi Tenggara.” Tesis Magister Pendidikan. Surabaya: PPs Universitas Negeri Surabaya.

Slavin, R. E, 1997. Educational Psychology Theory Into Practice. Edisi 6. Boston: Allyn \& Bacon.

Sugiman. 2011. Peningkatan Pembelajaran Matematika dengan Menggunakan Pendekatan Matematika Realistik. (Online). Tersedia pada: http://staff.uny.ac.id/ Diakses tanggal 10 Februari 2017.

Suherman, Erman. 1986. Strategi Belajar Mengajar Matematika. Jakarta Dirjen Dikdasmen Depdikbud.

Sutarto, H. 2005. Pendidikan Matematika Realistik. Tulip: Banjarmasin.

Suprihatiningrum, J. 2013. Strategi pembelajaran: Teori \& Aplikasi. Yogyakarta: Ar-Ruzz Media.

Treffers, A. 1991. Didactical background of a mathematics programm for primary education', in L. Streefland (ed.), Realistic Mathematics Education in Primary School, CD- $\beta$ Press / Freudenthal Institute. Utrecht University, Utrecht: The Netherlands, pp. 21-56.

Usman, Uzer. 2001. Upaya Optimalisasi Kegiatan Belajar Mengajar. PT Rosda Karya. Bandung.

Wijaya, Ariyadi. 2009. Hypothetical Learning Trajectory dan Peningkatan Pemahaman Pengukuran Panjang. Makalah disampaikan dalam Seminar Nasional Matematika, pada tanggal 5 Desember 2009 di Yogyakarta.

Zulkardi dan Ilma. 2006. Mendesain Sendiri Soal Kontekstual Matematika. Prosiding Konferensi Nasional Matematika XIII. Semarang: IndoMS. 


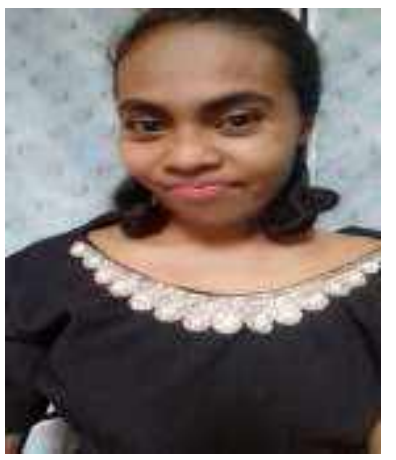

\section{Riwayat Hidup}

Emy Sohilait, lahir di Allang pada tanggal 5 Juni 1990, anak kelima dari lima bersaudara, ayah bernama Reinholp Sohilait (Alm) dan ibu bernama Selfina Huwae.

Mengawali jenjang pendidikan di SD Inpres Allang, Kecamatan Leihitu pada tahun 1996 dan lulus pada tahun 2002. Pada tahun yang sama pula melanjutkan studi di SMP Kristen 1 Allang dan lulus pada tahun 2005. Pada tahun yang sama pula melanjutkan studi di SMA Kristen 1 Amahai, Kecamatan Amahai dan lulus pada tahun 2008. Tahun 2008 melanjutkan studi ke Sekolah Tinggi Keguruan Dan Ilmu Pendidikan (STKIP) Gotong Royong Masohi pada Jurusan Pendidikan Matematika dan Ilmu Pengetahuan Alam, program studi Pendidikan Matematika dan lulus pada tahun 2013. Pada tahun 2015 melanjutkan studi pada Program Studi Pendidikan Matematika PPs Universitas Negeri Manado.

Penulis terdaftar sebagai mahasiswa Program Studi Pendidikan Matematika Universitas Negeri manado di Tondano pada tahun 2015 dengan NIM: 15811010.

Tondano, September 2017

Penulis

Emy Sohilait 